\title{
Evidence of decoupled deformation during Jurassic rifting and Cenozoic inversion phases in the salt-rich Corbières-Languedoc Transfer Zone (Pyreneo-Provençal orogen, France)
}

\author{
Antoine Crémades* (1), Mary Ford (1) and Julien Charreau (D) \\ Université de Lorraine, CNRS, CRPG, 54000 Nancy, France
}

Received: 1 December 2020 / Accepted: 7 June 2021 / Publishing online: 30 August 2021

\begin{abstract}
A detailed field study of Jurassic tectono-stratigraphic architecture of the southwestern part of the Corbières-Languedoc Transfer Zone (CLTZ, NE-SW oriented), between the Pyrenean and Provençal orogenic segments (N110 oriented) in SE France, document for the first time variations in thickness and stratigraphic geometries in relation to oblique extensional cover structures (NE-SW and N110 oriented). These structures (low-dip normal faults, salt rollers, rollovers, forced folds) formed during a Jurassic extension phase with strong decoupling between basement and cover on the Keuper pre-rift salt (CarnianNorian evaporites). Some of these structures such as the Treilles Fault, the Valdria and the Terres Noires fold pairs, were previously interpreted as compressional and Pyrenean in origin (Late Santonian-Bartonian). Our study instead shows that these are Jurassic extensional and salt related structures, which were later affected by Pyrenean compression and Oligo-Miocene extension. Evidence of Jurassic extension is still observable in the field despite later rectivations, making these good field analogs for gently inverted extensional salt structures. During the Jurassic the interference between oblique structures above Keuper, leads to the formation of three dimensional growth strata observable at kilometric scale. Despite the mechanical decoupling effect of Keuper, we infer that their formation was linked to a strong interaction between oblique basement structures (NE-SW and N110) as the area lies during the Jurassic at the intersection between the eastern part of the Pyrenean E-W trending rift system and the NE-SW trending European margin of the Alpine Tethys rift. The decoupled deformation and the strong segmentation above and below Keuper detachement are here identified as Jurassic structural inheritence for later tectonic events, notably for the Nappe des Corbières Orientales emplaced at the end of Pyrenean orogenesis. Associated to previous works, this study highlights that the CLTZ is a key area to better understand Pyreneo-Provençal system evolution along its whole Wilson cycle and to better understand the processes that govern the formation of a salt-rich transfer zone in a strongly pre-structured crust, its multiple reactivations and the decoupling role of salt.
\end{abstract}

Keywords: transfer zone / salt tectonic / decoupled extension and inversion / oblique structures / Corbières / Alpine Tethys-Pyrenees

Résumé - Évidences de déformation découplée pendant le rifting Jurassique et les phases d'inversion Cénozoïques dans la Zone de Transfert Corbières-Languedoc riche en sel (Orogène Pyrénéo-Provençal, France). Notre étude de terrain détaillée de l'architecture tectono-stratigraphique des séries jurassiques de la partie sud-ouest de la Zone de Transfert Corbières-Languedoc (CLTZ, orientée NE$\mathrm{SW}$ ), entre les segments orogéniques pyrénéen et provençal (orientés E-W), documente pour la première fois l'existence de variations d'épaisseur et de géométries stratigraphiques en relation avec des structures extensives de couverture obliques (orientées NE-SW et N110). Ces structures et les géométries associées (failles normales à faible pendage, salt roller, anticlinaux en rollover, plis forcés) se sont formées en relation avec une phase d'extension d'âge Jurassique et un fort découplage entre le socle et la couverture par les dépôts salifères anté-extension du Keuper (Carnien-Norien). Certaines de ces structures comme la Faille de Treilles, les plis de Valdria et de Terres Noires, étaient interprétées comme compressives en relation avec l'orogénèse pyrénéenne (fin du Santonien-Bartonien). Notre étude montre qu'il s'agit en fait de structures extensives jurassiques réactivées lors de la compression pyrénéenne puis lors de l'extension oligo-miocène.

*Corresponding author: antoine.cremades@univ-lorraine.fr 
Les évidences d'extension jurassique restent observable sur le terrain malgré les réactivations ultérieures et font de ces structures des analogues de terrain pour les structures salifères extensives légèrement inversées. Au Jurassique, l'interférence entre ces structures extensives obliques au dessus du Keuper, à conduit à la formation de géométrie stratigraphique 3D observables à l'échelle du kilomètre. Malgré l'effet de découplage mécanique du sel, nous proposons que leur formation aient été étroitement liées au jeu de structures extensives de socle orientées N110 et NE-SW, puisque la région se trouvait au Jurassique à l'intersection entre la partie orientale du rift pyrénéen orienté N110 et la marge européenne du rift de la Tethys alpine orientée NE-SW. La déformation découplée et la forte segmentation au dessus et en dessous du Keuper sont ici identifiés comme un héritage structural d'âge Jurassique pour les évènements tectoniques postérieurs, notamment pour la Nappe des Corbières Orientales mise en place à la fin de l'orogénèse Pyrénéenne. Associée aux travaux antérieurs, cette étude montre que la CLTZ est une zone clé pour mieux comprendre l'évolution du système pyrénéo-provençale tout au long de son cycle de Wilson et pour mieux comprendre les processus qui régissent la formation d'une zone de transfert riche en sel dans une croûte fortement pré-structurée, sa multiple réactivation et le rôle du découplage du sel pré-rift lors des différentes phases de déformation.

Mots clés : zone de transfert / tectonique salifère / extension et inversion découplées / structures obliques / Corbières / Pyrénées-Tethys Alpine

\section{Introduction}

In extensional systems, transfer zones correspond to major relay zones, which accommodate the extension between large (typically $100-\mathrm{km}$ scale) rifted domains and can involve secondary relay structures of various scales (e.g. transfer faults, relay ramps, fractures) (e.g. Fossen and Rotevatn, 2016). In rifted margins (McKenzie, 1978; Peron-Pinvidic et al., 2013; Reston, 2009; ref. therein), the formation and evolution of rift transfer zones and their control by inherited basement anisotropy, have been widely studied (Bellahsen et al., 2013; Bosworth, 1985; Faulds and Varga, 1998; Gawthorpe and Hurst, 1993; McClay et al., 2002, Morley et al., 1990; Schlische and Withjack, 2009). However, the study of inversion of rift transfer zones during convergence, including their basement structures and syn-rift basins, is limited to a few models (Konstantinovskaya et al., 2007) and field examples (e.g. Quintana et al., 2006), while inverted margins are relatively well studied (Conand et al., 2020; de Graciansky et al., 1989; Mohn et al., 2010; ref. therein). In the specific case of inverted salt rich rifts (e.g. Espurt et al., $2019 \mathrm{~b}$ ), the formation and the reactivation of transfer zones remain poorly understood, due to a lack of investigations. A first order difficulty in understanding these zones is the decoupling of deformation between sub-salt basement and supra-salt cover that controls sedimentary basin structure. Basin development is strongly dependent on many parameters like the initial spatial and thickness distribution of salt, the prerift basement architecture, the amount of deformation, sedimentation rate and many others (Jackson and Hudec, 2017). The degree of decoupling on salt often makes it difficult to distinguish: (1) syn-rift halokinetic structures from superimposed shortening in the supra-salt cover and (2) basement structure evolution below salt during extension and inversion. Furthermore, gravitational sliding on salt at any stage of an inverted margin's history can further complicate reconstruction of rift history (e.g. Jackson and Hudec, 2017). During extension, accommodation space is generated by extensional basement faults and halokinetic activity that forms complex tectono-stratigraphic structures. Salt structures tend to develop in association with basement normal faults while elsewhere the salt layer can thin to form primary salt welds (Warsitzka et al., 2013; Withjack and Calloway, 2000). During inversion the most intense shortening above basement locates in salt structures near or above basement faults, forming secondary welds and thrust welds (e.g. Ford and Vergés, 2021; references therein).

In this study, we investigate the Pyrenean-Provençal realm, well known to have recorded a full Wilson cycle with Mesozoic rifting followed by late Mesozoic to Cenozoic collision, with halokinetic activity during each phase on Keuper (Carnian-Norian) evaporites detached above Variscan basement (Espurt et al., 2019a, 2019b; ref. therein). Indeed, numerous studies focusing on the Pyrenean orogenic domain, in particular on the retro-wedge and the retro-foreland basin (Fig. 1), highlight the major role of inheritance of the Mesozoic rifting phases and of salt tectonics in the inversion style and in the orogenesis (e.g. Ford and Vergés, 2021; Labaume and Teixell 2020; ref. therein). Furthermore, the PyreneanProvençal orogen is affected by a major (110 km wide) salt rich transfer zone, the so-called Corbieres-Languedoc Transfer Zone (CLTZ), NE-SW oriented, that connects the Pyrenean $(400 \mathrm{~km})$ and Provençal $(300 \mathrm{~km}) \mathrm{E}-\mathrm{W}$ orogenic segments (Fig. 1b; Arthaud and Mattauer, 1972; Arthaud and Séguret, 1981; Barnolas and Courbouleix, 2001; Lacombe and Jolivet, 2005; Tavani et al., 2018) (Figs. 1 and 2). As in the main Pyrenean-Provencal domains, we can expect that in this major transfer zone, Mesozoic inherited rift and salt structures played a major role during Pyrenean inversion. The CLTZ therefore represents an area where we can study the processes that govern the formation of a salt-rich transfer zone in a strongly prestructured crust, its positive inversion and the role of salt during these different deformation phases.

While the orogenic and post-orogenic phases of the CLTZ have been well described (e.g. Bache, 2009; Barnolas and Courbouleix, 2001), the preceding rifting phases are poorly understood. The Triassic to Cretaceous lithostratigraphy is well established for the area (Fig. 3), especially in the Corbières Virgation (SW part of the CLTZ, Figs. 1b and Figs. 2a, b) where, in contrast to the Languedoc Virgation 


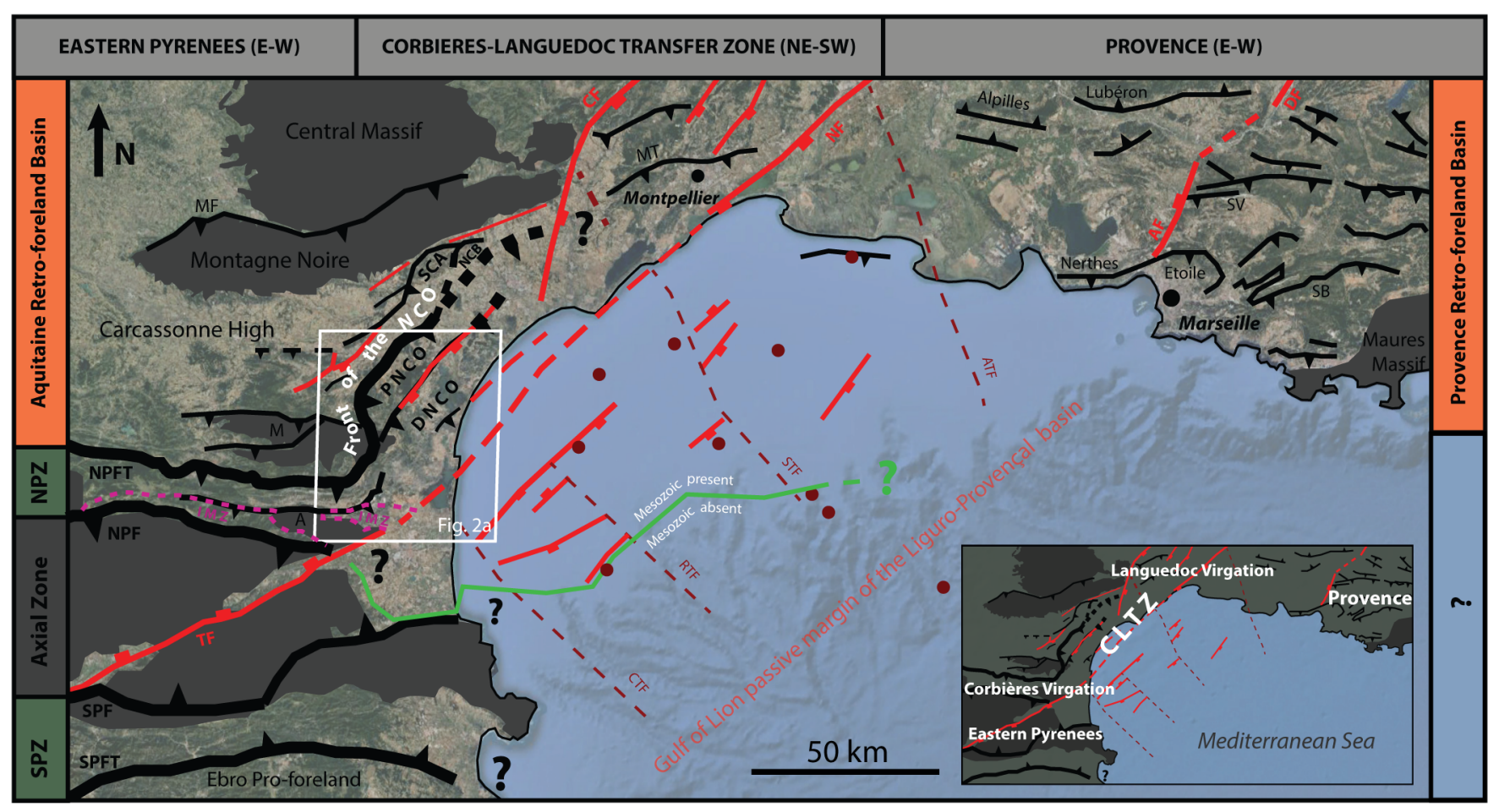

(b)
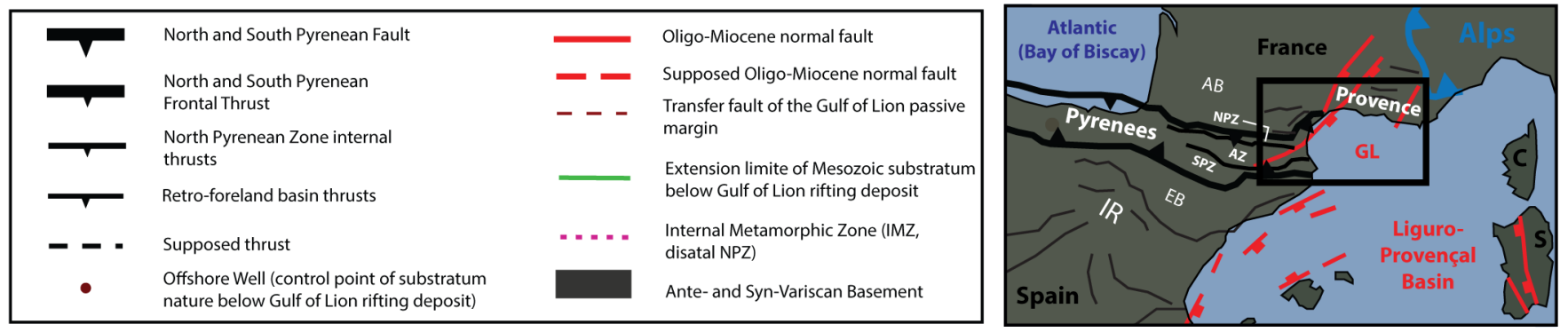

(a)

Fig. 1. (a) Simplified map of the Pyrenean-Provençal orogen and Gulf of Lion margin showing the location of the map in b. Abbreviations are C: Corsica; S: Sardinia; GL: Gulf of Lion; AB: Aquitaine Basin; NPZ: North Pyrenean Zone; SPZ: South Pyrenean Zone; EB: Ebro Basin; IR: Iberian Range. (b) Structural map of the Eastern Pyrenees - Provence linkage zone (Corbières-Languedoc Transfer Zone), showing the main orogenic domains and features as well as Oligo-Miocene extensional features. Locations of Figure 2 are boxed in white. At the bottom right is a simplified sketch of the map in b showing main regional domaines in white. Abbreviations are CLTZ: Corbières-Languedoc Transfer Zone; NPFT: North Pyrenean Frontal Thrust; NPF: North Pyrenean Fault; SPF: South Pyrenean Fault; SPTF: South Pyrenean Frontal Thrust; NCO: Nappe des Corbières Orientales; PNCO: Proximal Nappe des Corbières Orientales; DNCO: Distal Nappe des Corbières Orientales; SCA: SaintChinian Arc; NCB: Nappe de Cazoul-les-Béziers; MF: Mazamet Fault; MT: Montpellier Thrust; TF: Têt Fault; NF: Nîmes Fault; CF: Cevennes Fault; AF: Aix-en-Provence Fault; DF: Durance Fault; CTF: Catalan Transfer Fault; RTF: Rascasse Transfer Fault; STF: Sète Transfer Fault; ATF: Arles Transfer Fault; M: Mouthoumet massif; A: Agly Massif; SV: Sainte Victoire; SB: Sainte Baume.

(NE part of the CLTZ, Fig. 1b), the Mesozoic rifting series crops out (Alabouvette et al., 1985; Berger et al., 1982, 1993, 1997; Ellenberger et al., 1987; Lespinasse et al., 1982), and where first order variations in thickness and facies have been identified (Debrand-Passard et al., 1984; Fauré 1980; Fauré and Alméras 2004, 2006). Similarly, while the presence of Triassic salt is well established and its potential importance in regional tectonic history has been discussed (Gorini et al., 1991; Mattauer and Proust, 1962; Rouvier et al., 2012;
Viallard, 1987), no detailed examination of possible Mesozoic salt related rift structures has been carried out.

By focusing on the tectono-stratigraphic architecture and the kinematic calendar of the Jurassic basins of the Corbières Virgation (SW part of the CLTZ) (Figs. 1b and Figs. 2a, b), this study aims to clarify the nature of the CLTZ within the early Mesozoic rift system (Jurassic) in order to better understand the reactivation of this complex area during Pyrenean convergence. To do this, we present a synthesis of the Jurassic 

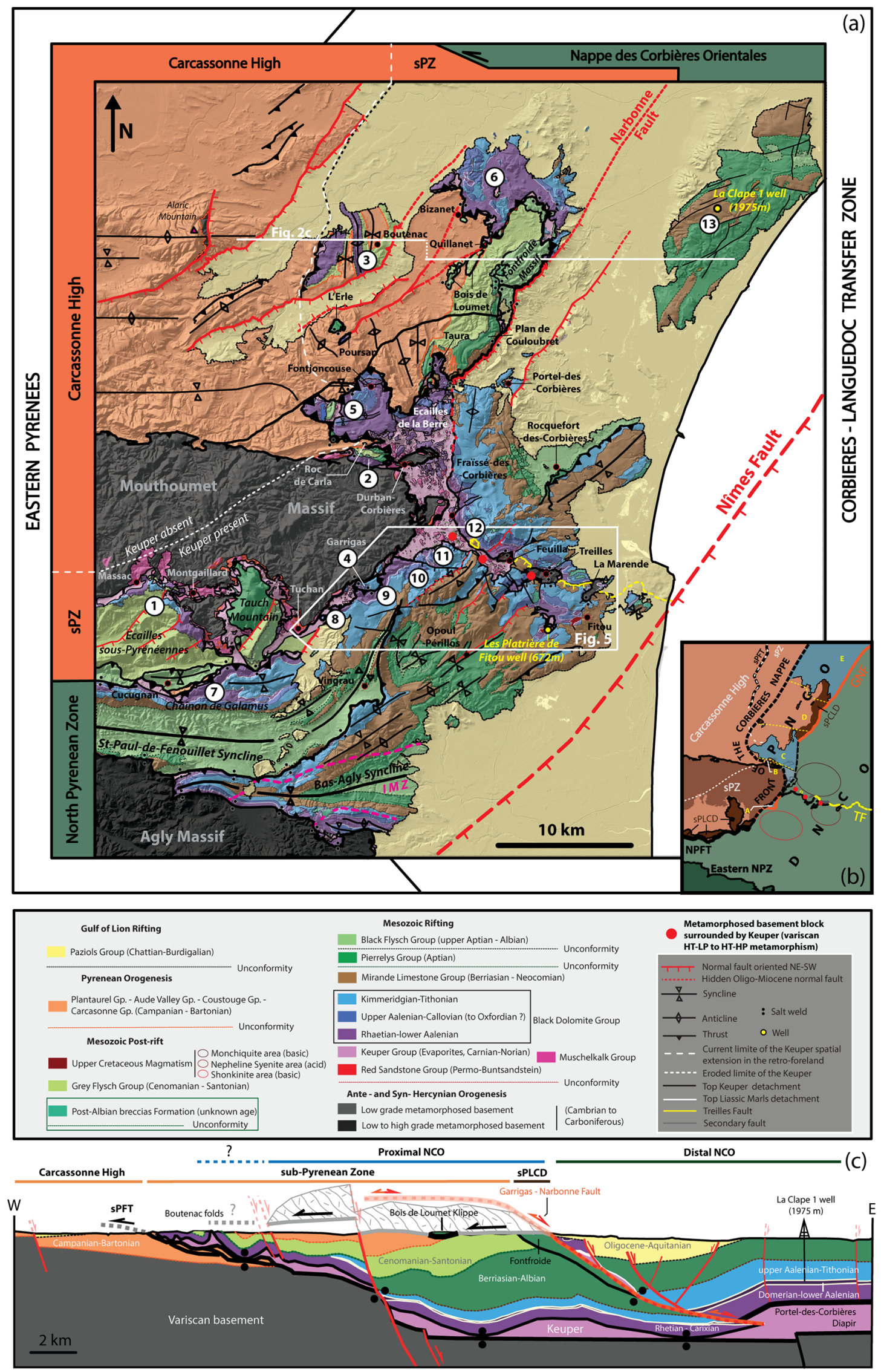
Fig. 2. (a) Geological map of the Corbières Virgation, SW part of the Corbières-Languedoc Transfer Zone, showing the location of the study area (Fig. 5) and of the g"'g' cross-section. Jurassic stratigraphic columns of Figure 4 are located by number on the map. (b) Structural map of the Corbières Virgation showing the main orogenic domains and tectonic units defined in this paper. (c) E-W cross section of the Corbières Virgation (map trace located on Fig. 2a) showing the current relationship between the differents orogenic domains in the supra-salt cover (PNCO, DNCO, sPZ, Carcassonne high) (modified after Gorini et al., 1991). The section also illustrates the complex regional tectonic history and the decoupling effect of Keuper evaporites between supra-salt cover and sub-salt basement during deformations phases.

stratigraphy across the area (based on our data and published data) and a detailed field study of key sectors of the Nappe des Corbières Orientales (Fig. 2), to investigate the role of tectonics and salt in controlling variations in Jurassic stratigraphy.

\section{Tectonic setting}

\subsection{Pyrenean-Provençal realm}

The Pyrenean-Provençal orogen constitutes the western end of the Himalayan-Alpine orogenic belt and extends for more than $700 \mathrm{~km}$ from Cantabria in the west (Spain) to the Alps in the east (France) (Fig. 1a). The strongly asymmetric doubly vergent orogenic prism formed at the Iberian-European Plate Boundary (IEPB) (Tugend et al., 2015) by the tectonic inversion of a complex Mesozoic rift system (Tavani et al., 2018), in response to the Africa-Iberia-Europe convergence (Macchiavelli et al., 2017; ref. therein). Deep seismic lines (ECORS) show the Iberian plate subducted towards the north below the European plate (Choukroune et al., 1990; Espurt et al., 2019a, 2019b; Mouthereau et al., 2014). Total shortening during this orogenic phase is relatively modest and ranges between $100 \mathrm{~km}$ and $165 \mathrm{~km}$ in the western and central part of the Pyrenees s.s. (Beaumont et al., 2000; Mouthereau et al., 2014; Roure et al., 1989; Teixell et al., 2016). In the eastern part of the chain, the shortening gradually decreases eastward, from 111-125 km (Grool et al., 2018; Vergés et al., 1995), to $45 \mathrm{~km}$ near the CLTZ (Ternois et al., 2019). The mountain belt is made up of five distinct tectonostratigraphic units (Fig. 1): the Axial Zone (AZ) comprising a stack of south verging Iberian upper crustal imbricates, the South and the North Pyrenean Zone (SPZ and NPZ), a south and a north verging fold-and-thrust belts, the Ebro basin (EB; pro-foreland basin) and the Aquitaine basin (AB; retro-foreland basin). The AZ, SPZ and EB belong to the Iberian plate (lower plate), the NPZ and the $\mathrm{AB}$ belong to the European plate (upper plate).

During the breakup of Pangea (here named the Mesozoic extension phase), the Pyrenean area constituted the northernmost branch of a highly segmented extensional system that developed across and around the Iberian microplate, to link the Atlantic to the Alpine Tethys extensional domain (Angrand et al., 2020; Rat et al., 2019; Tugend et al., 2015).

A first phase of rifting is recorded during late Permian and Early Triassic (linked to Neotethys, Angrand et al., 2020). This period ended with the deposition of evaporites (Keuper, Carnian-Norian) that spread all over Western Europe and Iberia (Soto et al., 2017).

During the Lias to Dogger the opening of the Central Atlantic Ocean propagated northward, west of Iberia (Nirrengarten et al., 2018), connecting by the Gibraltar transfer zone (south of Iberia) to the NE-SW oriented Alpine Tethys rift system that developed from the Betics to SE France
(Angrand et al., 2020; Célini et al., 2020, Espurt et al., 2019a; Handy et al., 2010; Schettino and Turco, 2011). During this period, gentle subsidence is recorded in Iberian and Pyrenean basins (Angrand et al., 2020; Canérot et al., 2005; Espurt et al., 2019b; Rat et al., 2019). The Alpine Tethys rifting stopped between the Bajocian-Bathonian and the Oxfordian (Angrand et al., 2020) with the onset of oceanic spreading. Post-rift thermal subsidence of Alpine rifted margins continued until the onset of convergence (Late Santonian, Handy et al., 2010; Lemoine et al., 1986).

A major sinistral strike-slip displacement between the Iberian and Eurasian plates occurred between Malm and end Albian. The spatial distribution and timing of this deformation within and around the Iberian plate remains strongly debated (Angrand et al., 2020; Olivet, 1996; Sibuet et al., 2004). From Malm to early Aptian the basins of the Iberian Ranges underwent strong subsidence in contrast to the Pyrenean basins. To the east, an E-W subsiding area formed in Provence (Southeast basins of France, Tavani et al., 2018). During Malm-Berriasian, the Aquitaine area was overprinted by a poorly understood phase of uplift and erosion named the Neocimmerian transpressional event (Canérot et al., 2005). A similar phase of uplift affected Provence (Durance Isthmus, Tavani et al., 2018). From late Aptian to Early Cenomanian, intense extension was located between the Iberian and Eurasian plates with a decreasing intensity from west (Bay of Biscay, Pyrenees) to east (Provence) (Fig. 1a). Lithospheric mantle was exhumed along the distal rifted margins of the Pyrenean domain (Lagabrielle et al., 2010) leading to localised HT-LP metamorphism in overlying basins (Internal Metamorphic Zone, e.g. Clerc et al., 2015; Golberg and Maluski, 1988; Fig. 1b).

Mesozoic extension was followed by a post-rift subsidence phase. In the Pyreneo-Provençal area, this phase started in Late Cenomanian and continued for some 10 Myrs before the onset of Pyrenean orogenesis (Angrand et al., 2018). In latest Santonian Africa began to converge with Europe (e.g. Handy et al., 2010) initiating convergence in both the western Alps (Apulia-Europe) and in the Pyrenees (Iberia-Europe). Pyrenean orogenesis is recorded from latest Santonian to Miocene (Mouthereau et al., 2014). An early orogenic phase from the latest Santonian to the late Maastrichtian was followed by a phase of orogenic quiescence in the Paleocene before the onset of main collision in early Eocene, which lasted until Miocene (Angrand et al., 2018; Ford et al., 2016; Rougier et al., 2016).

From the early Oligocene to Miocene, the eastern part of the Pyreneo-Provençal orogen was largely destroyed by the opening of the Gulf of Lion and Liguro-Provençal back-arc basin (Fig. 1) (Bache et al., 2010; Gattacceca et al., 2007; Guennoc et al., 2000; Jolivet et al., 2015, 2020). This phase of extension occurred in response to slab rollback in the Apennine subduction zone and leads to the anti-clockwise rotation of the Corso-Sardinian block (Jolivet et al., 2015). 
Thus, only the lateral equivalent of the proximal North Pyrenean Zone (in the CLTZ) and retro-foreland depocentres (CLTZ to Provence) are preserved along the French Mediterranean coast (Bache et al., 2010) (Fig. 1). The prolongation to the east in the CLTZ of an equivalent of the distal NPZ as well as the pro-wedge units (ZA, ZSP, Ebro basin; Fig. 1) is not demonstrated (Arthaud and Mattauer, 1972; Arthaud and Séguret, 1981; Bache, 2009; Barnolas and Courbouleix, 2001; Rouvier et al., 2012; Séranne, 1999). Based on a synthesis of interpretations of offshore sismic profiles and offshore wells (Bache, 2009), the estimated extension limit of Mesozoic strata below the Cenozoic succession of the margin is shown in Figure $1 \mathrm{~b}$ (green line).

\subsection{Corbières-Languedoc Transfer Zone}

The Corbières-Languedoc Transfer Zone trends NE-SW (Fig. 1b) and curves at its ends through two virgations (Fig. 1b): the Corbières Virgation that connects with the Pyrenean segment to the SW and the Languedoc Virgation that connects to the Provençal segment to the NE. The CLTZ includes (Fig. 1): (1) the NE-SW oriented Cévenole fault system, major basement to cover features; (2) the Mesozoic cover of the Nappe des Corbières Orientales (NCO), a major cover feature corresponding to inverted Mesozoic rift basins detached above Keuper evaporites and emplaced onto the foreland; (3) the foreland of the NCO, which is the most eastern part of the Aquitaine retro-foreland basin.

\subsubsection{General stratigraphy}

Lithostratigraphic formations of the Corbières Virgation (Fig. 2a, b) are defined on the basis of the Bureau de Recherches Géologiques et Minières (BRGM) 1:50,000 maps and memoirs (Berger et al., 1982, 1993, 1997; Ellenberger et al., 1987; Lespinasse et al., 1982). Formations are organized in groups (Fig. 3) (Ford et al., 2016; Rougier et al., 2016), which are here associated with the main tectonic phases defined above.

Paleozoic Variscan basement of the Mouthoumet massif, the Feuilla, La Marende, and Treilles inliers and the basement outcropping in the Alaric Mountain, consists of low grade metamorphosed carbonate and clastic units (Ordovician to Carboniferous) and associated magmatic bodies (Berger et al., 1997; Fig. 2a). Paleozoic LT-LP to HT-LP metamorphic rocks are found in the Agly massif (distal NPZ), at the bottom of the Platrières de Fitou well (672 m, MT-LP, Destombes, 1949) and as allochtonous blocks in the Keuper below the NCO (HT-LP to HT-HP) (Fig. 2a). The Upper Permian-Buntsandstein or Red Sandstone Group consists of a fluvial clastic succession that was deposited unconformably on Paleozoic basement. The limestones and dolomites of the Muschelkalk Group (middle Trias) were deposited during the first post-variscan marine transgression.

The Keuper (Carnian-Norian p.p., Keuper Group), also named the salt in this study, consists of dolomites and cargneules (dedolomitized limestones) and variegated marls with intercalations of gypsum sometimes massive and rich in bipyramidal quartz. Below the NCO, east of the Embres-et-Calstelmaure meridian (Fig. 2a), the Keuper evaporites were intruded by spilites (also named ophites, altered basalt) during the magmatic phase of the Central Atlantic Magmatic Province (CAMP; Azambre, 1967; Béziat et al., 1991; Montigny et al., 1982). As is the case in many peri-Mediterranean alpine chains, the original thickness and distribution of the Keuper in the Corbières cannot be constrained. This is linked to the mobility of plastic Keuper marls and evaporites during extensional and compressional phases and linked to evacuation of evaporites during sub-aerian erosion due to their high solubility (e.g. Jackson and Hudec, 2017). In the studied area, observed Keuper thicknesses are very variable, in particular below the NCO, with a maximum of $645 \mathrm{~m}$ at the level of the Platrières de Fitou well (Destombes, 1949; Figs. 2a and 5) while elsewhere the thickness can be reduced to $0 \mathrm{~m}$ in certain localities (e.g. front of Garrigas unit, Feuilla half-window, Treilles and La Marende windows, Figs. 2a and 5). The Keuper at the base of the NCO includes allochthonous blocks (up to tens of meters wide) of substratum (Palaeozoic basement, Muschelkalk) and Jurassic strata, interpreted as witnesses of the important tangential shear at the base of the NCO (Lespinasse, 1965; Raymond, 1965; Vila, 1964).

The Rhaetian to end Jurassic (Black Dolomite Group, describe in detail below in Section 2.2.2) and the Neocomian Early Aptian (Mirande Group), are characterized by essentially carbonate platform deposits (limestones, marls, dolomites). The Pyrenean rift climax is recorded from Aptian to Early Cenomanian across most of the range (Angrand et al., 2020). However, based on avable dates in the Corbières Virgation, the corresponding sedimentary record ranges from Aptian to Albian in age (Pierrelys and Black Flysch Groups) and is characterised by sandy-rich marine carbonates, with an enrichment in detrital during the deposition of the Black Flysch Group.

The Cenomanian-Santonian Grey Flysch Group consists of marine carbonates, marls and clastics. This unit records the post-rift thermal subsidence phase. It is absent in the NCO due to erosion as upper Albian. This period is also marked by the intrusion of undersaturated alkaline magmas (nepheline syenites, monchiquites and shonkinites, Figs. $2 b$ and 5) in the NCO (Azambre, 1967, 1970; Golberg et al., 1986; Montigny et al., 1986).

Although Pyrenean orogenesis is recorded from latest Santonian to Miocene (Mouthereau et al., 2014) in the central and western Pyrenees, the syn-orogenic sedimentary record of the Corbières Virgation ranges from Campanian to Bartonian in age. It can be found only in the foreland where it is characterized by fluvial, lacustrine and marine deposits (Plantaurel Group, Aude Valley Group, Coustouge Group, Carcassonne Group; Grool et al., 2018).

During the opening of the Gulf of Lion (OligoceneMiocene), fluvial, lacustrine and marine deposits of the Paziol Group (Chattian-Burdigalian) infilled a series of graben and half-graben and unconformably overlie partly eroded Mesozoic units of the NCO and its foreland.

Post-Albian breccias of unknown deposition age $(\mathrm{CBr})$ occur sporadically across the NCO (Fig. 5). These sedimentary breccias, whose youngest elements are dated to the Albian, may be linked to the Mesozoic post-rift phase, to syn-orogenic phases or to rifting of the Gulf of Lion. 


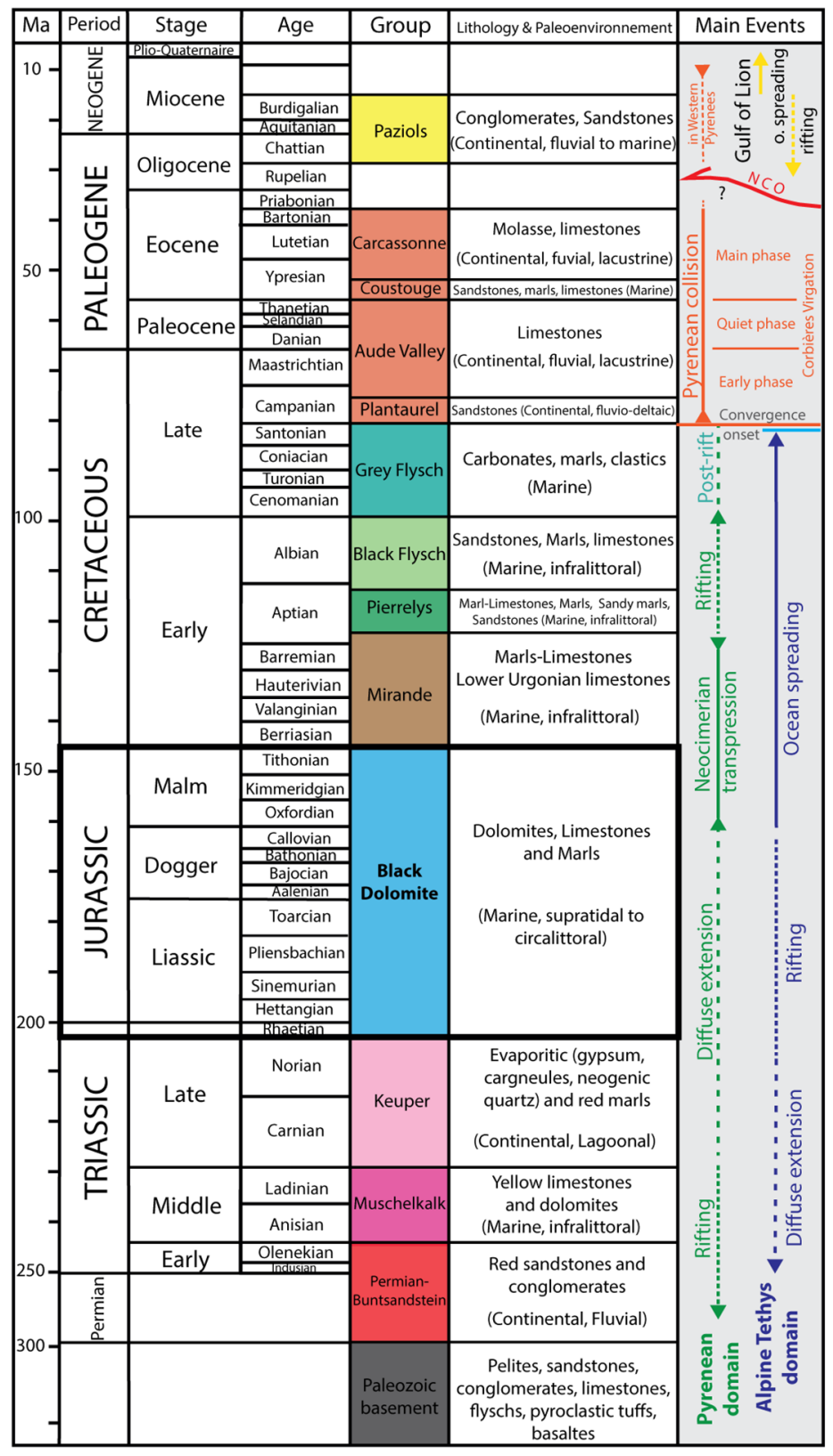

Detailed stratigraphy of the Black Dolomite Group

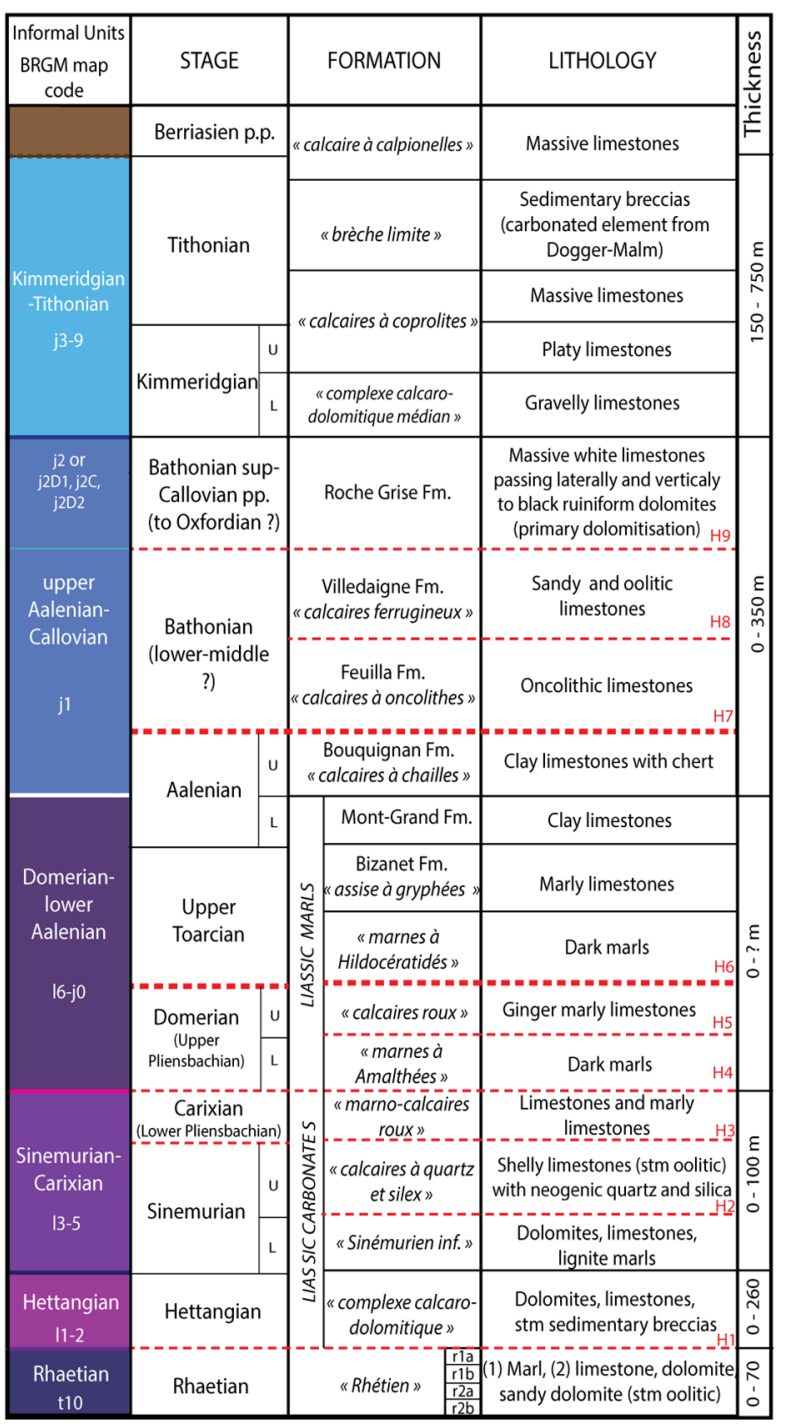

Fig. 3. Left: table summarizing the general lithostratigraphy of the Corbières Virgation from Paleozoic to Miocene with a synthesis of the main tectonic events. Right: table summarizing the detailed lithostratigraphy subdivisions of the Black Dolomites Group found in the Corbières Virgation, derived from BRGM geological maps $(1 / 50,000)$ and many others studies. Red dashed lines represent unconformities (H1 to H9). Abreviations are H: Hiatus/Unconformity; L: lower; U: upper.

\subsubsection{Detailed lithostratigraphy of the Black Dolomite Group}

The detailed lithostratigraphy of the Black Dolomite Group (Rhaetian-Tithonian) is based on regional and local studies (Fauré, 1980; Fauré and Alméras, 2004, 2006; Sarfati, 1964), PhD theses (Donnadieu, 1973; Vila, 1964), BRGM maps at 1: 50,000 (Berger et al., 1982, 1993, 1997; Ellenberger et al., 1987; Lespinasse et al., 1982) and a BRGM regional synthesis (Debrand-Passard et al., 1984). The Black Dolomite
Group is characterized by relatively homogenous littoral to external platform limestones, dolomites and marl facies. For the purposes of this study the group is separated into six informal units (Fig. 3). These informal units have been defined by the BRGM with a corresponding map code (Fig. 3). In this study we use map codes of the Leucate map (Berger et al., 1982).

The Rhaetian to Carixian (lower Pleinsbachian) units together form the Liassic Carbonates. The Rhaetian unit (t10) is made up of marls overlain by a well bedded series of 
limestones and dolomites. The Hettangian unit (11-2) consists of a thinly bedded limestone-dolomite succession. The Sinemurian-Carixian unit (13-5) is made up of three formations of marls and limestones (Sinémurien inférieur Fm., Calcaires à quartz et silex Fm., Marno-calcaires roux Fm., Fig. 3).

The Domerian (upper Pleinsbachian) - lower Aalenian unit (Liassic marls and limestones, 16-j0) is subdivided into five formations (Marnes à Amalthées Fm., Calcaires roux Fm., Marnes à Hildocératidés Fm., Bizanet Fm., Mont-Grand Fm., Fig. 3). The lower Toarcian is absent (unconformity H6, Fig. 3).

The upper Aalenian-Callovian unit (Dogger limestones and black dolomites, $\mathrm{j} 1$ and $\mathrm{j} 2$ or j2D1, j2C, j2D2) comprise 4 limestones formations (Bouquignan Fm., Feuilla Fm., Villedaigne Fm., Roche Grise Fm., Fig. 3) the last being often affected by early dolomitisation (Sarfati, 1964) leading to a poorly defined upper limit (Callovian or Oxfordian). The Bajocian is absent in the Corbières (unconformity H7, Fig. 3).

The Kimmeridgian-Tithonian unit (Malm Limestones, j3-9) is characterized by 3 limestones formations (Complexe calcaro-dolomitique médian Fm., Calcaires à calprolites Fm., Calcaire à calpionelles Fm., Fig. 3) with intraformational carbonate breccias (Brèche limite Fm., Fig. 3).

\subsubsection{Structure of the Corbieres-Languedoc Transfer Zone}

\subsubsection{NE-SW Cévennes basement cutting faults}

A major basement feature of the CLTZ is the presence of a network of NE-SW oriented (Cévenole direction) faults such as the Cévennes and Nimes faults (Fig. 1). These are the principal transfer faults of the transfer zone, thought to be inherited from a late Variscan orogenic phase (Angrand et al., 2020; Arthaud and Laurent, 1995; Arthaud and Mattauer, 1972). They are supposed to have been variably reactivated during three phases (1) Mesozoic rifting (Angrand et al., 2020; Arthaud and Laurent, 1995; Berger et al., 1997; Debrand-Passard et al., 1984; Tavani et al., 2018); (2) Pyrenean orogenesis (Late Santonian - Early Miocene) (Arthaud and Durand, 1982; Barnolas and Courbouleix, 2001; Lacombe and Jolivet, 2005) and (3) Oligo-Miocene extension, where most of the transfer zone formed the northwestern margin of the Liguro-Provençal back-arc basin (Gulf of Lion passive margin, Fig. 1) (Bache et al., 2010; Gattacceca et al., 2007; Gorini et al., 1991, 1993; Guennoc et al., 2000; Huyghe et al., 2020; Jolivet et al., 2015, 2020; Mascle et al., 1996; Mauffret et al., 2001; Séranne, 1999; Viallard and Gorini, 1994). During the different tectonic phases, the reactivation of these inherited faults appear to have strongly influenced the orientation of structures in the overlying sedimentary cover, producing structures of various nature and ages (e.g. Pyrenean thrusts, Gulf of Lion normal faults, Fig. 2a, c). Some supra-salt strutctures are documented to have been inverted, for example, Gorini et al. (1991) interpret the NE-SW oriented Narbonne Fault (Fig. 2a) as a supra-salt Oligo-Miocene normal fault that partially negatively reactivated a Pyrenean thrust (Fig. 2c). However, the direct linkage between sub-salt and supra-salt structures cannot often be directly demonstrated.

\subsubsection{Eastern Aquitaine retro-foreland}

The Aquitaine and Provençal retro-foreland basins (Fig. 1b) developed in response to the growth of the topographic load of the Pyrenean-Provençal orogen (Angrand et al., 2018). The south eastern termination of the Aquitaine basin developed in the north-western part of the Corbières Virgation (Figs. 1b and 2). Two subzones are here defined, based on the current distribution of Keuper evaporites above basement (see the estimated current extension limit of Keuper in the foreland, Fig. 2) (Barnolas and Courbouleix, 2001):

- The sub-Pyrenean Zone (sPZ) (Berger et al., 1997) which has a Keuper detachment level and Mesozoic rifting strata unconformably overlain by post-rift or syn-orogenic strata. It is divided into two zones, (a) the sub-Pyrenean Lower Cretaceous Depocentres (sPLCD; Cucugnan, Tauch mountain, Plan de Couloubret, Fontfroide massif, Fig. 2) where supra-Keuper cover is deformed in parallel to the main orogenic faults (NPFT and FNCO, Fig. 2), (b) the rest of the sPZ (Écailles sous-Pyrénennes, Pinède de Durban, Boutenac area and Saint Chinian Arc, Figs. 1b and 2a, c) comprizes a supra-Keuper cover constituted of Jurassic to Eocene deposits that is folded in parallel to the extension limit of the Keuper (Fig. 2).

- The Carcassonne High (Figs. $1 \mathrm{~b}$ and 2), which was not affected by Mesozoic extension (Angrand et al., 2018; Ford et al., 2016), is characterized by a stratigraphic hiatus ranging from the Carboniferous to the base of the Maastrichtian (Christophoul et al., 2003; Ellenberger et al., 1987). This hiatus is due either to (1) non deposition of sediments during Mesozoic rifting associated or not to basement erosion as it is documented for post-rift phase (regional unconformity topped by bauxite) or to (2) erosion of thin Mesozoic basins and basement strata during postrift phase. Contrary to the $\mathrm{SPZ}$, the absence of Keuper here favored a thick-skinned deformation during the orogenic phases associated with syn-sedimentary growth folds (Fig. 2) (Christophoul et al., 2003).

The basement of the foreland basin crops out to the south in the Mouthoumet massif and to the north in the Montagne Noire (Fig. 1b). In the eastern Mouthoumet massif (Fig. 2a), the basement forms a N100 trending anticline (Mouthoumet anticline) that is documented to develop during Pyrenean orogenesis (Campanian to Bartonian, with a probably later activity) above an E-W basement thrust located at its northern edge (Christophoul et al., 2003; Robion et al., 2012). The eastern part of the massif is covered by the NCO, detached above the Keuper (Figs. 2a and 5) (Lespinasse, 1965; Raymond, 1965; Vila, 1964).

\subsubsection{The Nappe des Corbières Orientales}

The Nappe des Corbières Orientales (NCO, Figs. $1 \mathrm{~b}$ and 2 ) is the major orogenic cover feature of the CLTZ. The NCO was defined at the beginning of the 20th century (Barrabé, 1922, 1923, 1948; Bertrand 1906). Subsequent work, mainly produced between the years 1960 to 2000 , confirmed its existence and specified its relations with the foreland (Berger et al., 1982; Berger et al., 1997; Berger et al., 1993; 
Durand-Delga and Charrière, 2012; Ellenberger et al., 1987; Lespinasse et al., 1982; ref. therein). The NCO corresponds to a part of the original CLTZ Mesozoic basins that were inverted to form a wide nappe $(60 \mathrm{~km}$ long). This nappe is currently interpreted as the prolongation of the Eastern North Pyrenean Zone oriented N110 into the NE-SW trending transfer zone (Barnolas and Courbouleix, 2001; Barrabé, 1948; Viallard 1987). NE of Bizanet (Figs. 1 and 2a), the prolongation of the nappe in the Languedoc below Oligo-Quaternary deposits remains unknown, the front of the NCO being supposed to connect to the front of the Nappe de Cazoul-les-Béziers to the NNE (NCB, thusted above the Saint-Chinian Arc, Fig. 1b) (Barnolas and Courbouleix, 2001; Barrabé, 1938; Ellenberger, 1967). Eastward, the lateral NCO prolongation offshore in the Gulf of Lion remains uncertain due to later Oligo-Miocene extension (Figs. 1b and 2a, c) (Gorini et al., 1991; Mascle et al., 1996; Mauffret et al., 2001; Viallard and Gorini, 1994).

The NCO overthrusts the $\mathrm{SPZ}$ of the foreland (Charrière, 1979, 1980; Durand-Delga, 1964, Durand-Delga and Charrière, 2012; Jaffrezo, 1970; Viallard, 1963, 1987; Vila, 1965) with an estimated displacement of $10-20 \mathrm{~km}$ toward the NW or NNW (Fig. 2; Barnolas and Courbouleix, 2001; Cluzel, 1977; Durand-Delga, 1983; Ellenberger, 1967). Its emplacement is estimated to have taken place after the Bartonian (PriabonianRupelian?) as the youngest overthrust foreland sediments are Bartonian in age (Carcassonne Gp., Fig. 3) (Ellenberger et al., 1987) and as the Chattian to Burdigalian deposits related to Oligo-Miocene extension, unconformably overlie the NCO. To the SW, the nappe is detached above the eastern part of the Mouthoumet basement and its Permo-Triassic cover (Figs. 2a and 5) (Lespinasse, 1965; Raymond, 1965; Vila, 1964).

Above the Keuper, two ensembles are identified in the nappe (Berger et al., 1997; Cornet, 1980; Rouvier et al., 2012) (Fig. 3):

- The Proximal NCO (PNCO, Figs. 1b, Figs. 2 and 5) which overthrusts the syn-orogenic deposits of the sPZ, with a minimum observed displacement of $8 \mathrm{~km}$ to the NW-NNW (Berger et al., 1997; Viallard, 1987). This domain is mainly made up of isolated units due to erosion. We distinguish 4 units ( $1 \mathrm{~km}$ to $8 \mathrm{~km}$ wide) almost exclusively made up of Jurassic strata: the half-klippes of Bizanet (Zone E, Figs. 2a, b), Taura, Fontjoncouse and the klippe of Poursan (Zone C, Figs. 2a, b) (Charrière 1979, 1980; Dujon et al., 1964; Jaffrezo, 1970; Lespinasse et al., 1982; Viallard, 1987). The emplacement of this allochtonous domain onto the foreland extracted and transported footwall slices of Aptian to Cenomanian strata ( $200 \mathrm{~m}$ to $2 \mathrm{~km}$ wide) from the southern border of the sub-Pyrenean Zone (sPLCD). The relation between both can be observed in the area of the Taura unit (Charrière, 1979; Viallard, 1963, 1987; Zone C, Figs. 2a, b). Elsewhere these nappe slices formed isolated klippes on the sub-Pyrenean Zone (Zone D, Figs. 2a, b). We distinguish the klippes of Bizanet, Quillanet, Bois de Loumet, NW of Fontfroide, l'Erle (Zone D, Figs. 2a, b) and Roc de Carla (Zone B, Figs. 2a, b) (Barrabé, 1948; Casteras and Viallard, 1961; Dagnac, 1965; Dujon et al., 1964). To the SW the original prolongation of this domain above the Mouthoumet massif and its linkage with the eastern NPZ in the Tuchan area, remains unknown due to erosion. It has been suggested that the unit of Garrigas at the SE edge of Mouthoumet
(Zone A, Figs. 2a, b and 5) could correspond to a part of the PNCO prolongation (Berger et al., 1997; Raymond, 1965).

- The Distal NCO (DNCO, Figs. 1b and 2) is separated from the PNCO by the SE dipping Narbonne Fault (NF) in the NE part of the Corbières Virgation (Fig. 2a, c; Gorini et al., 1991). In the SW part of the Corbières Virgation, the DNCO is detached above the basement of the Mouthoumet massif. From Vingrau area, it passes to the SW in continuity to the basins constituting the eastern NPZ (Ducoux et al., 2021; Ford and Vergés, 2021), describing a structural virgation of approximately $55^{\circ}$, passing towards the west from a strike of N045 to N100 (Fig. 2a, b). In this area, the prolongation of the Internal Metamorphic Zone observed in the Bas-Agly syncline (eastern NPZ, Figs. 1b and 2a), to the E-NE below Oligo-Quaternary deposits of the CLTZ, remains unknown.

In a zone extending ESE from the Mouthoumet massif to the Mediterranean coast, the base and the footwall of the DNCO are uplifted in the core of a N110 trending open anticline (Barrabé, 1958) that is cut by the low angle Treilles Fault dipping SSW (Donnadieu, 1973; Rouvier et al., 2012) (Figs. 2a, b and 5). In the core of this anticline, the Feuilla tectonic half-window and the Treilles, La Marende windows (Figs. 2a and 5) expose Keuper and basement inliers with lithologies corresponding to those of the Mouthoumet massif (low grade metamorphosed basement). The significance of these basement inliers has been widely debated. Models include (1) autochthonous eastern prolongations of the Mouthoumet basement given the size (kilometric to plurikilometric) and the lithologies of basement inliers (Berger et al., 1982; Donnadieu, 1973; Jaffrezo 1977), and (2) allochthonous blocks within the Keuper (Barrabé, 1922; Donnadieu, 1973) given the presence in the Keuper evaporites of other smaller low grade metamorphosed basement blocks (in Embres-et-Castalmaure, Écailles de la Berre, Fontfroide and the Platrières de Fitou well; Figs. $2 \mathrm{a}$ and 5) as well as MTLP to HT-HP metamorphosed basement blocks, (in Fraïssédes-Corbières, Feuilla, Treilles and the Platrières de Fitou well; Fig. 2a) (Azambre and Rossy, 1981; Barrabé, 1922, 1923; Donnadieu, 1973; Leyreloup and Burg, 1976; Vielzeuf and Pin, 1991).

The DNCO is affected by weak NE-SW trending folds, which seem to attenuate from the eastern NPZ toward the NE, in particular across the Treilles Fault (Figs. 2a and 5). It is also affected by two major NW verging thrusts, the Vingrau Thrust and Rocquefort-des-Corbières Thrust, each dying out towards the Treilles Fault (Donnadieu, 1973) (Fig. 2a). The DNCO is cut by a network of faults, with varied orientations and kinematics (Figs. 2a and 5). NE-SW trending faults are predominantly normal faults down-throwing to the SE but also include subvertical dip-slip faults, thrusts with NW vergence and steeply dipping thrusts with SE vergence.

In addition to the Keuper basal detachment, the nappe includes secondary detachment levels that accommodated partitioning of deformation within the stratigraphic pile. These are the marly levels of the Domerian-lower Aalenian (Liassic Marls detachment) and those within the Aptian strata (Fig. 3) (Donnadieu, 1973). We stress the regional importance of the Liassic Marls detachment level which is often deformed, incomplete or absent (Donnadieu, 1973; Lespinasse, 1965; 


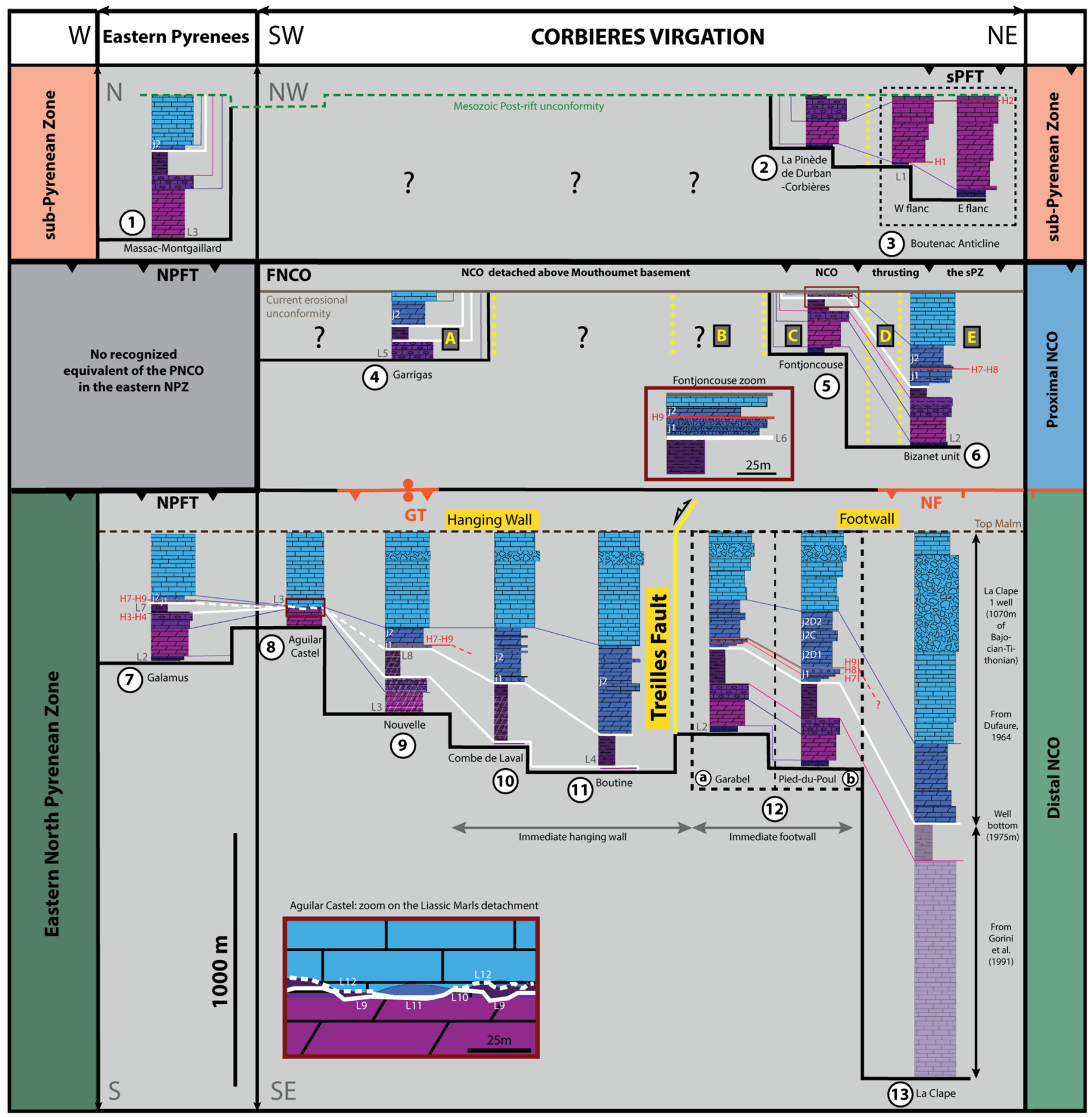

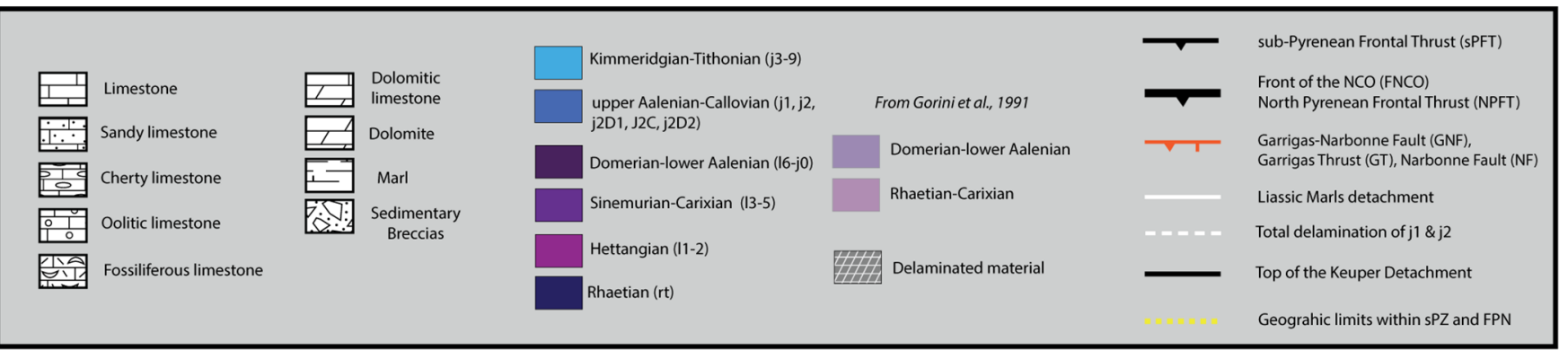


Fig. 4. Correlation chart of Jurassic stratigraphic units across and between orogenic domains of the Corbières Virgation. The domains and localities are shown in Figure 2. Columns 4 and 8 to 12 have been derived from our aa' and dd' cross-sections (Figs. 6a and 8c), the others come from litterature. Two detachment horizons are represented at the top Keuper (main detachment, in black) and in all or only at the top of the Liassic Marls (secondary detachment, in white). The Treilles Fault, cutting the DNCO, is represented in yellow. The letter L= delamination of: 1: r1a; 2: rla and r1b; 3: Rhaetian; 4: Rhaetian to Carixian (-Domerian); 5: Rhaetian to Hettangian; 6: Bizanet to Feuilla Fm.; 7: Bizanet Fm. to Bouquignan Fm.; 8: Upper Mont-Grand Fm.; 9: Sinermurian-Carixian; 10: Domerian-lower Aalenian; 11: Sinemurian-lower Aalenian; 12: upper Aalenian-Callovian. The unconformities identified in Figure 3 are represented.

Raymond, 1965; Vila, 1964) (Fig. 5). These marly levels were used by Cretaceous magmatism to migrate horizontally within the stratigraphic pile forming sills (Fig. 5).

\section{Jurassic thickness and lithological variations}

Based on a new correlation of key lithostratigraphic columns across the sub-Pyrenean Zone, the Proximal and the Distal parts of the NCO (Fig. 4), we here describe thickness and lithological variations in the Jurassic succession, as well as the distribution of stratigraphic units within the Corbières Virgation. All columns have been built by compiling data from literature (Berger et al., 1982, 1993, 1997; Debrand-Passard et al., 1984; Donnadieu, 1973; Ellenberger et al., 1987; Fauré, 1980; Fauré and Alméras 2004, 2006; Lespinasse et al., 1982; Sarfati, 1964; Vila, 1964). The columns 8 to 12 have been revised by constructing the aa' cross-section (Figs. 5 and 6a) presented in next section (Sect. 4.1). Most of the other columns have been verified by constructing sections that are not presented in this paper. The column 13 corresponds to the la Clape 1 well (1975 m; Dufaur, 1964). Figure 4 also includes representative logs for the eastern NPZ, for comparison with the transfer zone.

This correlation shows thickness variations of the Jurassic succession both from SE to NW and from SW to NE (Fig. 4). We stress that the most important thicknesses are found in the NE part of the Corbières Virgation and that a notable thickening is globally observed from the eastern Pyrenees toward the NE in the transfer zone.

At the base of the NCO, Liassic Carbonates are frequently tectonically delaminated between the Keuper detachment and the Liassic Marls detachment (Figs. 4 and 5) making documentation of thickness variations difficult across and between orogenic domains (sPZ, PNCO, DNCO). In areas where the Rhaetian unit (t10) is undisturbed, its thickness generally varies between $20 \mathrm{~m}$ and $40 \mathrm{~m}$, however local rapid variations ( $20 \mathrm{~m}$ to $70 \mathrm{~m})$ are observed in the Fontjoncouse and Taura units (PNCO) (Fig. 2a). The Hettangian unit (11-2) is often incomplete or absent in the Treilles Fault hanging wall (south compartment) in opposition to most of its footwall (north compartment) (DNCO). This unit presents a constant thickness in the PNCO (about 100 m, column 4, 5, 6, Figs. 2a and 4), however, it shows clear thickening from SW to NE in the sPZ, with a minimum of $80 \mathrm{~m}$ in Durban area (column 2, Figs. 2a and 4) and a maximum thickness in the N-S oriented Boutenac anticline to the NE (column 3, Figs. 2a and 4), where its thickness varies between the western flank $(200 \mathrm{~m})$ and the eastern flank $(350 \mathrm{~m})$. The Sinemurian-Carixian unit (13-5) presents a relatively constant thickness $(60 \mathrm{~m}$ to $100 \mathrm{~m})$ in the Corbières Virgation. Below la Clape 1 well (DNCO, column
13, Figs. 2a and 4) Gorini et al. (1991) speculatively propose a thick undifferentiated Rhaetian to Carixian series $(850 \mathrm{~m})$ on their cross-sectional model, which we include in column 13.

Most of the Carixian to Tithonian series are absent in the sPZ (regional unconformity, see Sect. 2.2.3). Only the base of the Sinemurian-Carixian is present in the Boutenac area while the Sinemurian to Domerian-lower Aalenian is present in the Durban area (Figs. 4 and 5).

The marl-rich Domerian-lower Aalenian unit (16-j0) constitutes a significant detachment level (Liassic Marls detachment, Donnadieu, 1973; Lespinasse, 1965; Raymond, 1965; Vila, 1964). It can be partially detached (only in its upper part, Toarcian-lower Aalenian marls) or totaly detached (Figs. 4 and 5). As a consequence, marked variations in thickness are observed, especially in the Treilles Fault hanging wall (e.g. $0 \mathrm{~m}$ in the Aguilar area, column 8, to $200 \mathrm{~m}$ in Laval area, column 10, Figs. 4 and 5).

The upper Aalenian-Callovian unit (Dogger limestones and black dolomites, j1; j2, or j2D1, j2C, j2D2) comprises 4 limestones formations (Fig. 3). The first three formations (upper Aalenian to lower Bathonian, j1) are thin (up to some $10 \mathrm{~s}$ of meters). The Feuilla Formation (second limestones formation, Figs. 3 and 4) is present in the DNCO but absent in the $\mathrm{SPZ}$ and in the PNCO. The last formation (Roche Grise Fm., upper Bathonian to Callovian or Oxfordian?) is largely affected by early dolomitisation (Sarfati, 1964) in the Treilles Fault hanging wall and footwall (DNCO). The spatial distribution and degree of early dolomitisation is the first order lithological variation in the Jurassic succession of the Corbières. Dolomitisation of the Roches Grises Formation is almost total in the western part of the Treilles Fault hanging wall, along the SE border of the Mouthoumet massif (j2, map code from Tuchan map, Berger et al., 1997) (Figs. 4 and 5). Conversely, in the Treilles Fault footwall and the eastern part of its hanging wall, the black dolomites (j2D1 and j2D2) are almost always separated by a limestone level (j2C) (Figs. 4 and 5), allowing a good resolution of thickness variations represented on cross-sections presented below. The upper Aalenian-Callovian unit presents an important thickening from SW toward NE in the PNCO (e.g. $20 \mathrm{~m}$ in Fontjoncouse, column 5, to $200 \mathrm{~m}$ in the Bizanet unit, column 6, Figs. 2a and $4)$ as well as in the Treilles Fault hanging wall $(0-10 \mathrm{~m}$ in the Aguilar area, column 8, to $350 \mathrm{~m}$ in the Boutine area, column 11) and footwall (180 m in Garabel area, column 12, to $320 \mathrm{~m}$ in la Clape 1 well, column 13, Figs. 2a and 4) (DNCO) which represents the most important thickness.

Limestones with intraformational breccias of the Kimmeridgian-Tithonian unit (Malm Limestones, 4 formations, Fig. 3) are fully preserved only in the DNCO (Figs. 2a and 5), where they present thickness variations from SW to NE in the Treilles Fault hanging wall $(300 \mathrm{~m}$ in Aguilar area, column 8 to $450 \mathrm{~m}$ in la Boutine area, column 11) as well as in 

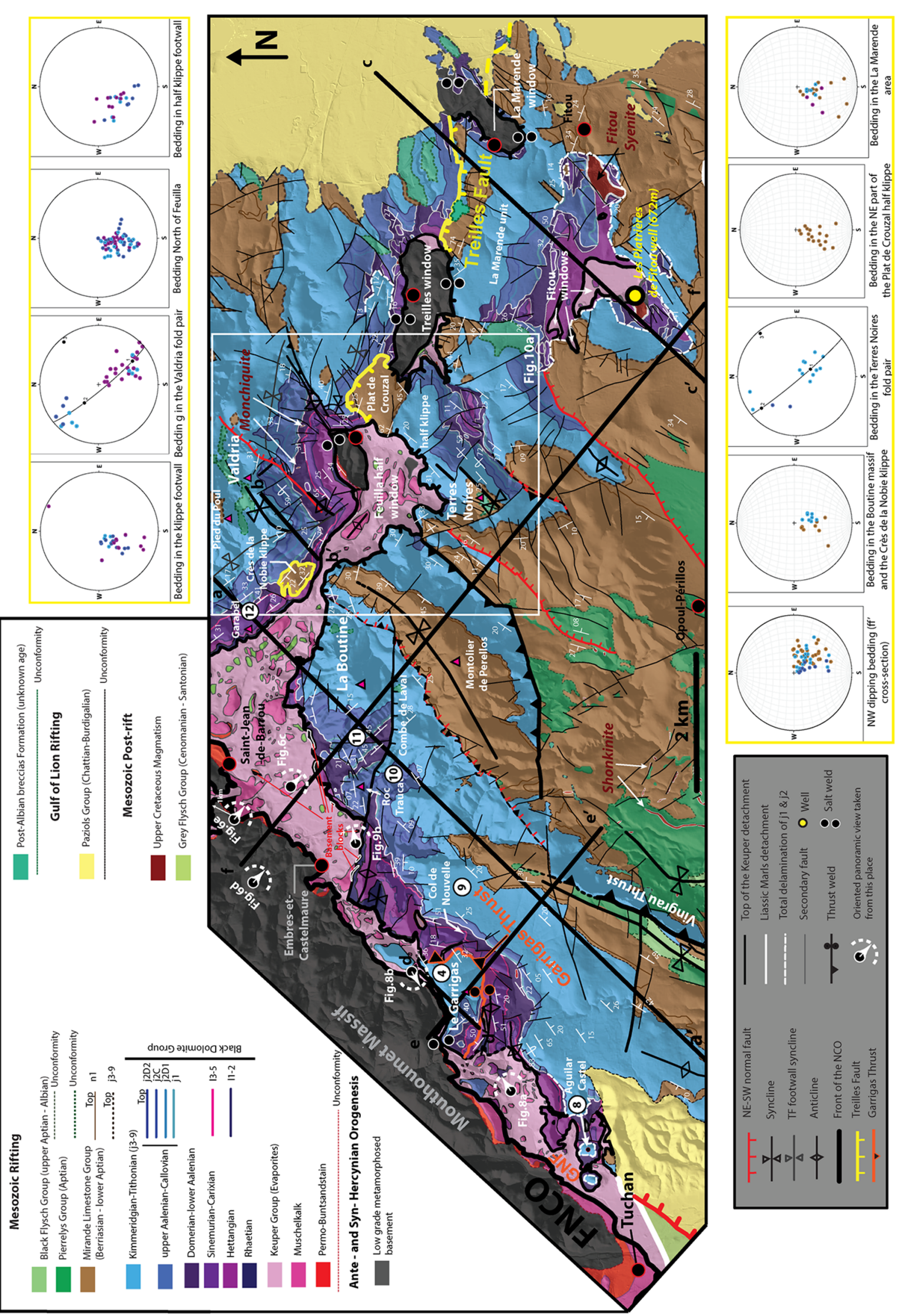

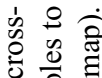

40

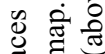

$\stackrel{\Xi}{ \pm} \equiv$

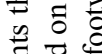

बे

는

. Ð

苍焉

$\bar{n}$ च

苂

$\sum_{0}^{\ddagger} \Xi$

을

류

걷

敢 要

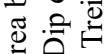

동

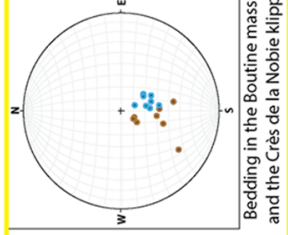

可 范

के

可

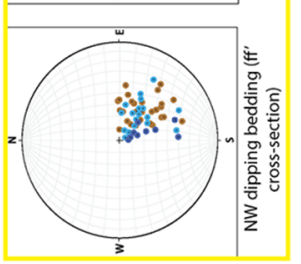

을

झे 음

는

ฟิ

छ

छ

苛总造

$\sum^{\circ} 50$

出

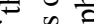

फ

훙 정

ธํㅠㅎำ

네응 응

은

‡

乙

을 홍

范声

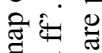

ฮ 을

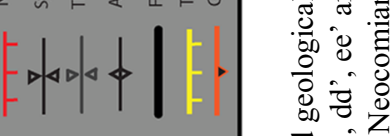

छ jं

运这公

. 콜

들 b

ம் 


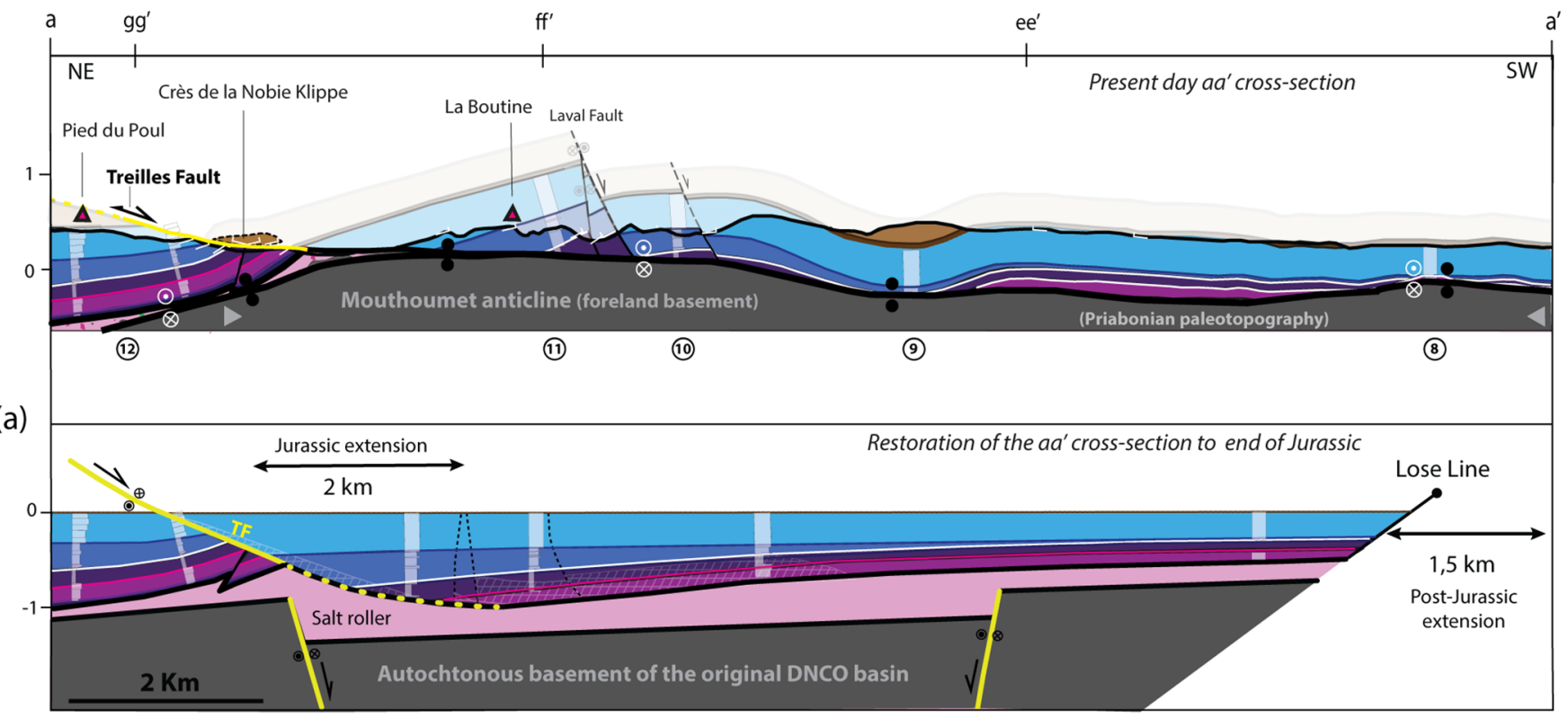

(b)

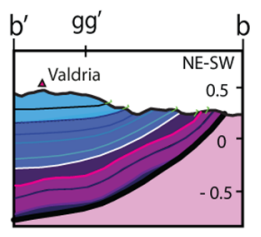

(c)
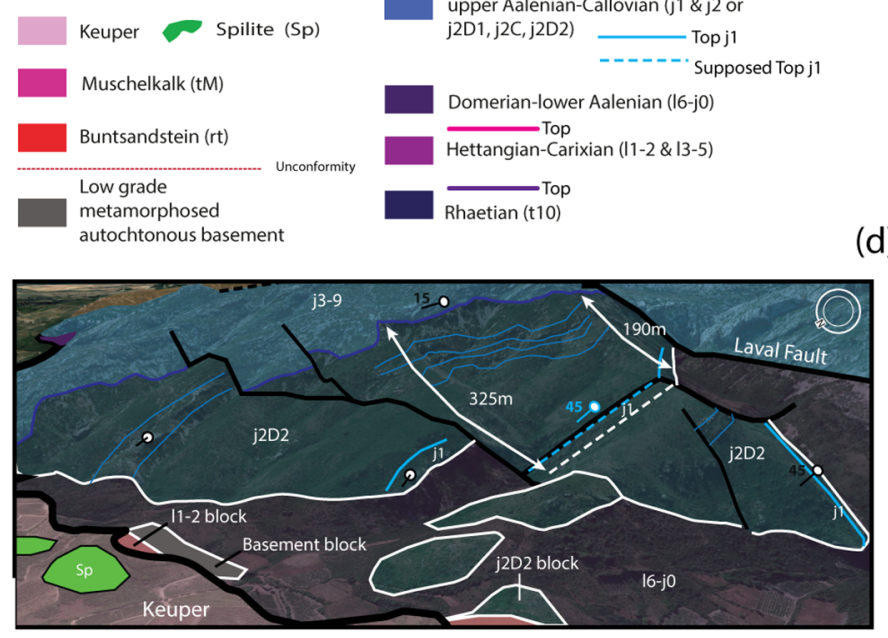

(d)
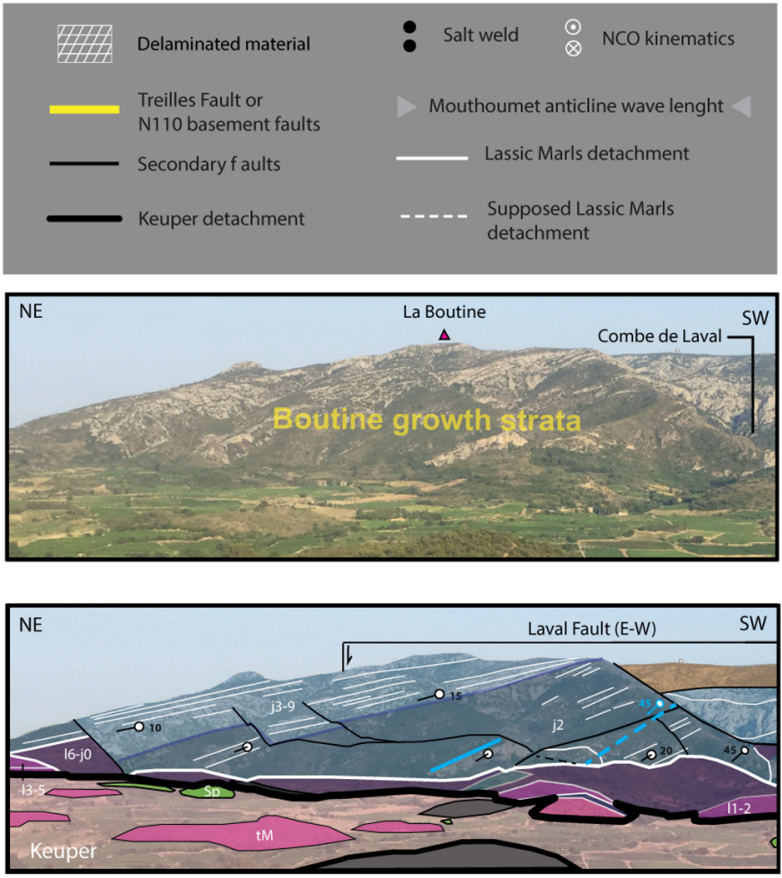

(e)

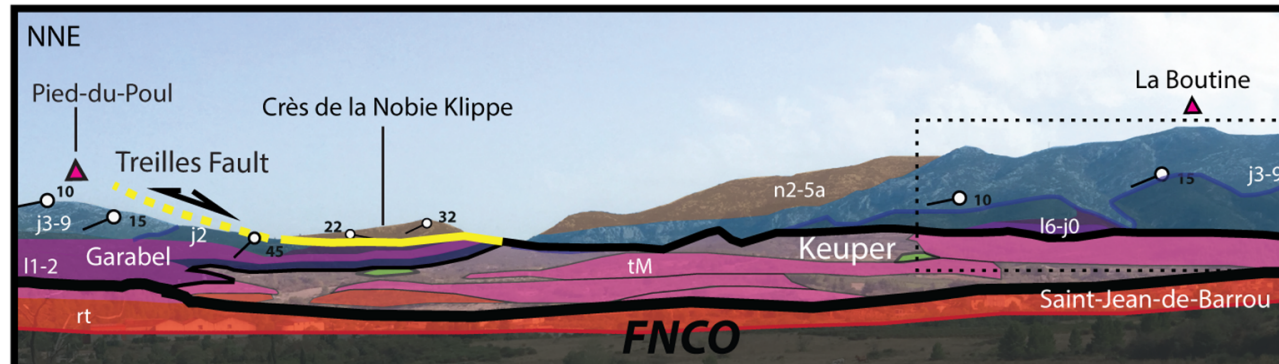

Mouthoumet massif 
Fig. 6. (a) Top: present day aa' cross-section oriented NE-SW (map trace on Fig. 5) showing the DNCO detached above the Mouthoumet massif and cut by the Treilles normal fault. Bottom: restoration of the aa' cross-section to end Jurassic showing the Jurassic displacement on the Treilles Fault recorded in stratigraphic thickness changes across the fault. Stratigraphic columns 8 to 12 of Figure 4 are represented on both sections. This thinskin fault is triggered by basement extension below salt during the Jurassic. (b) The NE-SE oriented bb' cross-section in the immediate footwall of the Treilles fault showing the Pied-du-Poul growth footwall syncline. (c) Interpreted Google Earth view of the Boutine Jurassic growth strata, that we interpret as an inverted rollover anticline developped in the Treilles Fault hanging wall. (d) Field view to the SE of the upper Aalenian-Tithonian Boutine inverted rollover with interpretation below. (e) Field view toward the SE of the Treilles Fault showing the relationship between its hanging wall and footwall.

the Treilles Fault footwall (250 $\mathrm{m}$ in Garabel area, column 12, to $750 \mathrm{~m}$ in la Clape area, column 13, Figs. 2a and 4).

\section{Reactivated jurassic extensional structures}

In this chapter, we present structural field data around key structures of the Proximal and the Distal parts of the NCO (Fig. 5) that are associated with thickness variations in the Jurassic succession. These structures are the Treilles Fault, the Garrigas unit, the Garrigas Thrust, the Valdria and the Terres Noires fold pairs (Fig. 5). These structures are described and interpreted on nine new cross-sections (aa', bb', Fig. 6; cc', Fig. 7; dd', ee', Fig. 8; ff', Fig. 9; g"g', hh'; Fig. 11, ii', Fig. 13). Restoration to end of Jurassic of sections aa', cc', ff' and gg' allowed us to build a block diagram (Fig. 14b) of the study area (map Figs. 5 and 14a).

\subsection{The N110 trending Treilles Fault}

Thickness variations from SW to NE in the Jurassic stratigraphic succession, around the Treilles Fault (Figs. 4 and 5) led us to carry out a detailed field investigation on this structure. The N110 trending, SSW dipping Treilles Fault (TF) cuts the DNCO into two compartments and roots into the Keuper along the southern margin of the Feuilla half-window and the Treilles and La Marende windows (Figs. 2a, b, 4 and 5). The fault extends over $12.5 \mathrm{~km}$ from the SE edge of the Mouthoumet massif to the Mediterranean coast (Donnadieu, 1973; Rouvier et al., 2012) (Figs. 2a, b and 5). As for the NCO, the original lateral extension of this fault is uncertain, due to erosion in the west and burial in the east below Oligo-Miocene deposits. The Treilles Fault is a normal fault that systematically juxtaposes Kimmeridgian to Neocomian strata of its hangingwall above Hettangian to Callovian strata of its footwall (Crès de la Nobie klippe, Plat de Crouzal half-klippe and La Marende unit, Fig. 5). Jurassic to Neocomian strata in the immediate hangingwall and footwall of the Treilles Fault generally have a $\mathrm{N}$ to NE dip (stereonet plots, Fig. 5) with the exception of two localized folds pairs (syncline-anticline pair), one in the footwall (Valdria fold pair), the other in the hangingwall (Terres Noires fold pair) (Fig. 5). These folds trend NE-SW with a NW vergence and will be examined in detail below (Sects. 4.6-4.9). As one moves SW into the Treilles Fault hangingwall, bedding rotates to NW dips (stereonet plots, Fig. 5).

Thickness and geometry variations in the Jurassic series associated with the Treilles Fault are here described along three NE-SW oriented cross-sections (Fig. 5), the aa' crosssection (Fig. 6a) on which have been placed the columns 8 to
12 from Figure 4, the bb' cross-section (Fig. 6b) and the cc' cross-section (Fig. 7). Only aa' and cc' sections traverse both fault blocks.

The aa' present day section (Fig. 6a) and the panoramic view of Figure 6e (location on Fig. 5) show the DNCO detached above the Mouthoumet anticline (15 km wide) and the Treilles Fault rooting onto the Keuper. On the section, the basement is represented as a Priabonian paleotopography (Viallard, 1987) and the NW-NNW oriented kinematics of the NCO is represented in white. The total estimated normal heave of the Treilles Fault on this section is about $3.5 \mathrm{~km}$. Below the Crès de la Nobie Klippe (Figs. 5 and 6a, e), the Jurassic series lies in a NW-SE trending footwall syncline (Pied-du-Poul syncline) with a dip fan on the steep limb, corresponding to a Jurassic growth strata. The growth strata are more pronounced on the bb' section (Figs. 6b, 10a and 11a) with dips decreasing upward from $79^{\circ} \mathrm{NE}$ in the Rhaetian to $10^{\circ} \mathrm{NE}$ in the Kimmeridgian. In the hangingwall the thickness of the Domerian-Tithonian succession increases from SW to NE over a distance of $12 \mathrm{~km}$, in particular the Domerian-lower Aalenian unit ( $0 \mathrm{~m}$ to $200 \mathrm{~m}$ on the section) and the upper Aalenian-Callovian unit (0-40 m to $350 \mathrm{~m})$ (Figs. 4 and 6a). We stress that the immediate hanging wall upper Aalenian to Tithonian units (Boutine area, column 11, Fig. 4) are thicker $(800 \mathrm{~m})$ than in the immediate footwall $(465 \mathrm{~m}$, Garabel area, column 12a, Figs. 4 and 6e). In the Boutine area, the NE dipping upper-Aalenian to Tithonian strata terminate downward onto the Liassic Marls detachment that lies just above the Keuper (over a distance of $2 \mathrm{~km}$ in the field, Figs. 5 and 6a, c, d). The dips decrease upward from $45^{\circ} \mathrm{NE}$ at the base of the upper Aalenian to $15^{\circ} \mathrm{NE}$ in the Kimmeridgian (stereonet plots, Fig. 5) describing an upper Aalenian-Kimmeridgian growth fan (Fig. 6a, c, d). These growth fan (Boutine growth strata) are cut by a series of steeply dipping faults such as E-W trending dextral transtensional faults dipping to the south (e.g. Laval Fault, Figs. 5 and 6a, c, d) and N-S oriented sinistral strike-slip faults (Figs. 5 and 6a, c, d). A basal chaotic zone of dismembered blocks of Rhaetian to Carixian units can be observed between the Liassic Marls and top Keuper detachments. Sub-salt blocks (Paleozoic and Muschelkalk) are observed close to the top Keuper detachment (Figs. 6 and 9b) and upper AalenianCallovian blocks are sometimes observed along the Liassic Marls detachment.

The cc' present day cross-section (Fig. 7) is parallel to the aa' section and crosses the eastern Treilles Fault in the Fitou area (Fig. 5). The section shows a broad, open $(8 \mathrm{~km})$ N110 trending salt-cored anticline (Fitou Anticline) whose hinge is cut by the Treilles Fault with an estimated SSW normal heave of $2.1 \mathrm{~km}$ (Fig. 7). The Keuper and the Liassic Marls detachments crop out in the Fitou tectonic windows where the Platrières de Fitou well (672 m, Destombes, 1949; Figs. 5 and 

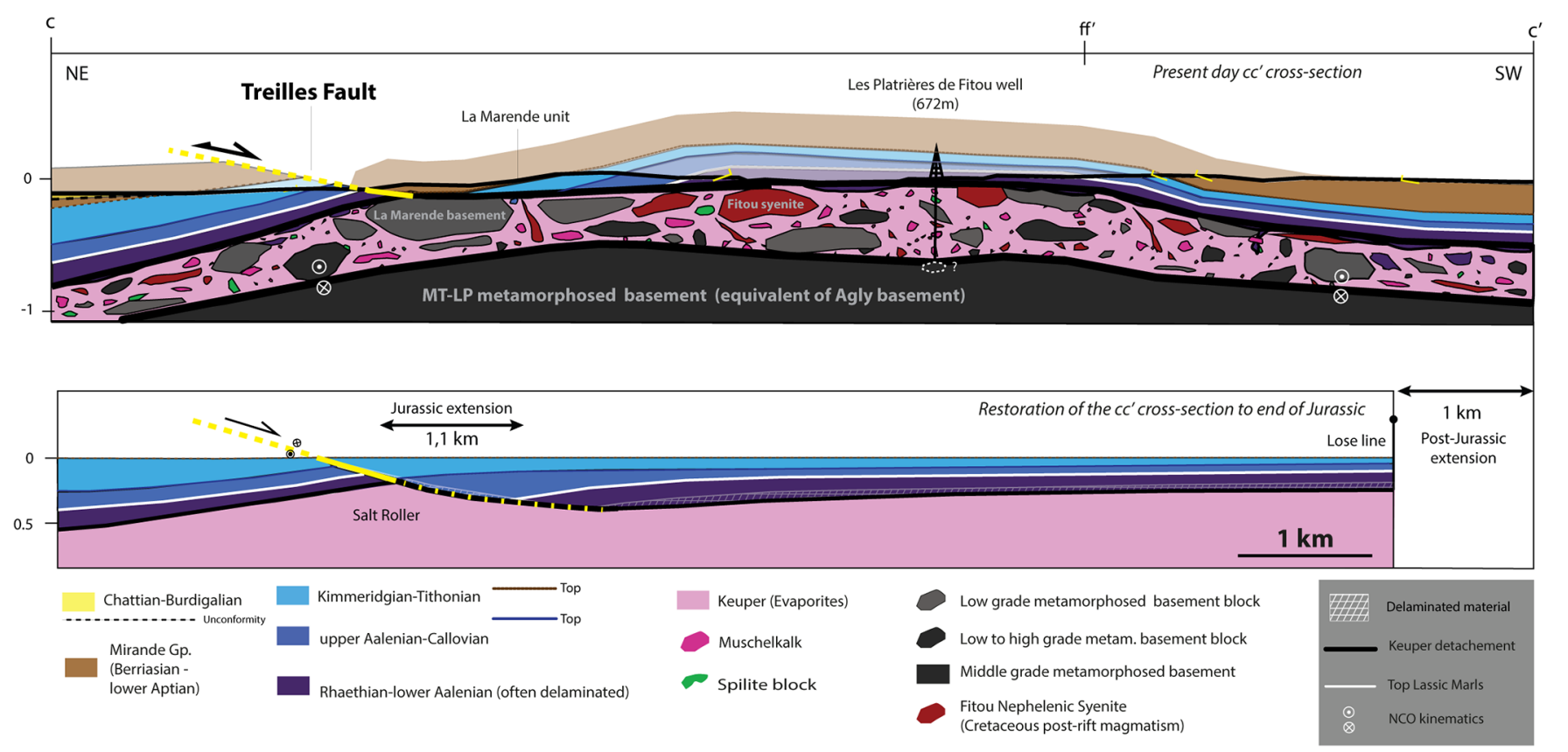

Fig. 7. Top: NE-SW oriented cc' cross-section across the hanging wall and the footwall of the eastern Treilles Fault (map trace on Fig. 5). The tie points with sections ff' is indicated. The Treilles fault here cut the hinge of the $8 \mathrm{~km}$ wide anticline of Fitou. The Platrières de Fitou well is represented onto the section. The metamorphosed basement (andalousite facies) at the bottom of the well is represented here as the prolongation of the Mouthoumet anticline affecting NPZ basement. Alternatively it could correspond to an allochtonous block. Bottom: the section is restored to end Jurassic to show the original geometry and displacement of the Treille Fault.

7) records Keuper evaporites with nepheline syenite, Triassic spilite, Muschelkalk and Paleozoic basement blocks down to $645 \mathrm{~m}$ (notably Muschelkalk blocks). We chose to represent the MT-LP basement lithologies intersected at the base of this well ( $27 \mathrm{~m}$ of thickness) as an autochtonous lateral equivalent of the Agly massif basement (distal NPZ basement, Fig. 2a) in the transfer zone as previously proposed (Barnolas and Courbouleix, 2001; Donnadieu, 1973). Alternatively it could correspond to an allochtonous block, implying a more important thickness of Keuper. We also chose to represent the basement as the eastward prolongation of the Mouthoumet Priabonian paleotopography suggested on aa' section (Fig. 6a). The Liassic Carbonates to Callovian series of the Treilles Fault hanging wall often occurs as dismembered blocks along and between the Keuper and the Liassic Marls detachment levels (Figs. 5 and 7). Dispite this, the upper Aalenian-Tithonian series is observed to gently thicken from SW to NE in the hanging wall of the fault, with an upper Aalenian-Tithonian unit in its immediate hanging wall (La Marende unit) that is thicker $(400 \mathrm{~m})$ than in the immediate footwall $(200 \mathrm{~m})$ but smaller than the Boutine growth strata describe above ( $800 \mathrm{~m}$, Fig. 6). Although poor outcrop prevents clear detection of Jurassic growth strata in the footwall and in the hanging wall, they are speculatively represented on cc' section to be consistent with geometries observed along the aa' and bb' sections.

\subsection{Interpretation of the Treilles Fault}

The N110 trending Treilles Fault has been variously interpreted as a Pyrenean thrust with N-NE vergence (Donnadieu, 1973; Jaffrezo, 1977), or as a lateral ramp allowing oblique thrusting of the hanging wall towards the NW (Viallard, 1987). Barnolas and Courbouleix (2001) and Rouvier et al. (2012) later suggested the possibility of a normal displacement of perhaps Oligocene age on the Treilles Fault but without supporting data. Our study documents for the first time thickness variations and growth strata that are evidence for Jurassic syn-sedimentary extensional folding parallel and linked to the Treilles Fault activity, in both its footwall and hanging wall. Based on the restoration to end of Jurassic of the aa' (Fig. 6a) and cc' (Fig. 7) sections, we propose that this fault originally formed as a Jurassic low-dip $\left(10-22^{\circ} \mathrm{SW}\right)$ thin skinned extensional fault, in association with a rollover anticline in its hanging wall (Boutine-La Marende rollover, Figs. 6a, c, d and 7), a growth syncline in its footwall (Pied-du Poul syncline, Figs. 6a, b) and a salt roller below the fault (Jackson and Hudec, 2017; Figs. 6a and 7). Our restorations imply a decrease in heave on the Treilles Fault from WNW (2 km, aa' restoration, Fig. 6a) to ESE $(1.1 \mathrm{~km}$, cc' restoration, Fig. 7). The basement represented on aa' section restoration corresponds to the original basement below autochtonous Jurassic basins before their mobilisation as the 
(a)

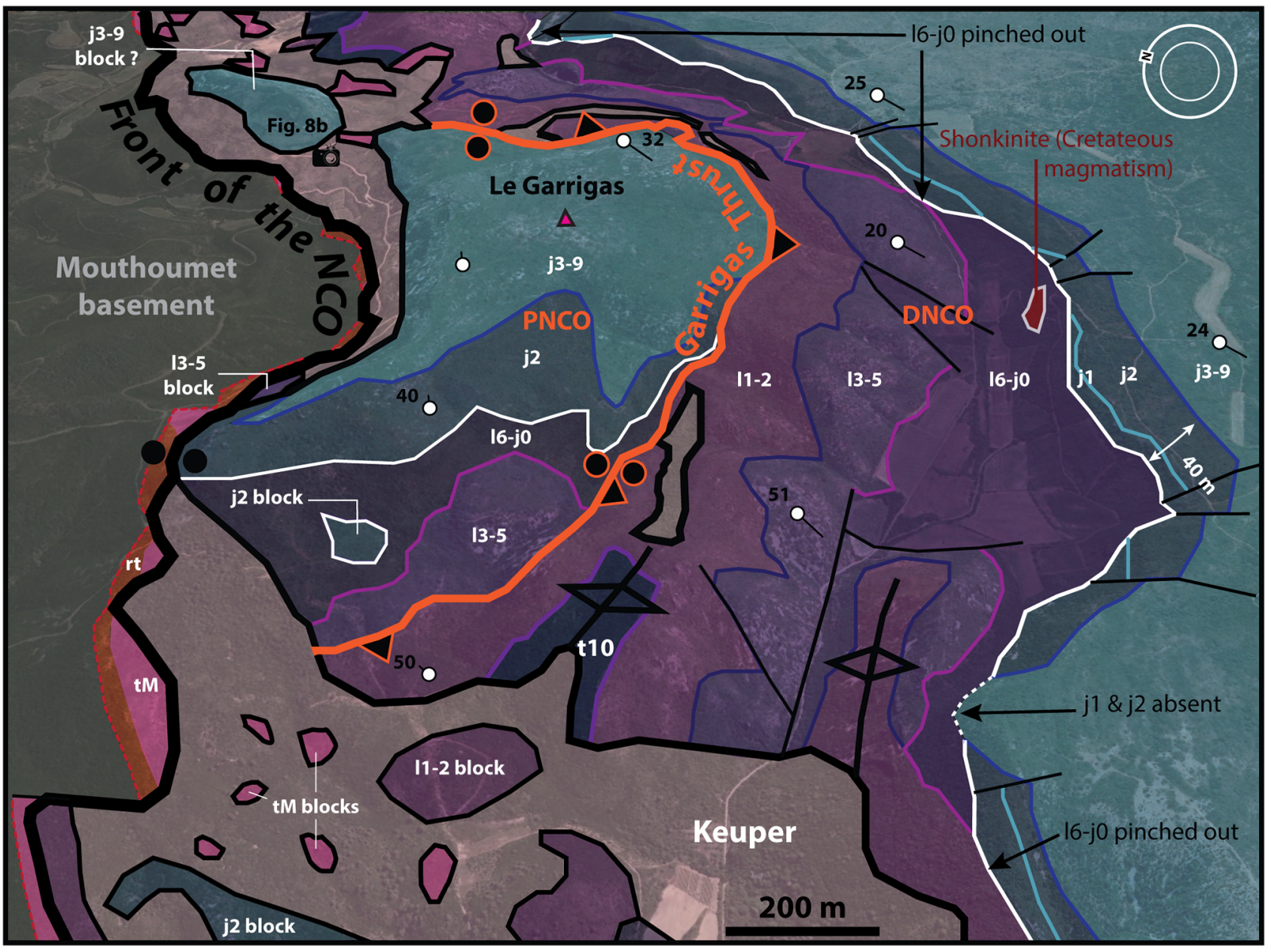

(b)
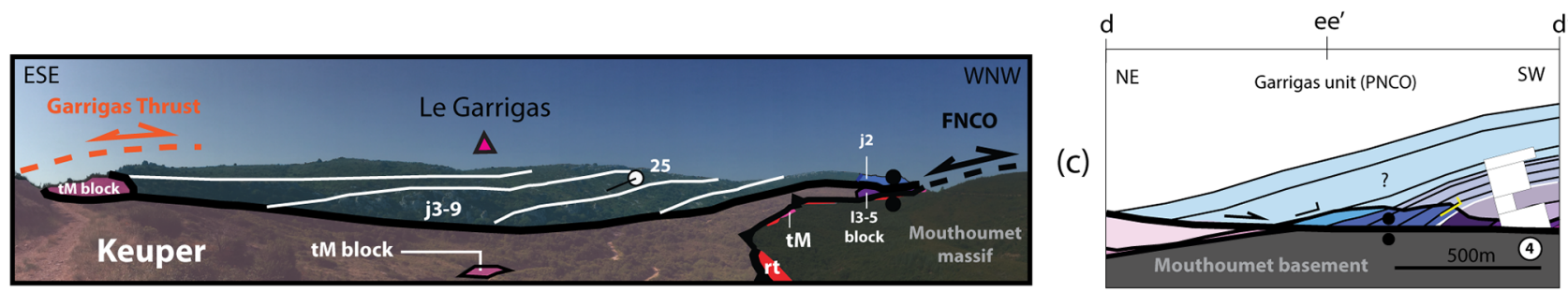

Mirande Limestone Gp.

(Berriasian - lower Aptian) Top $j 3-9$

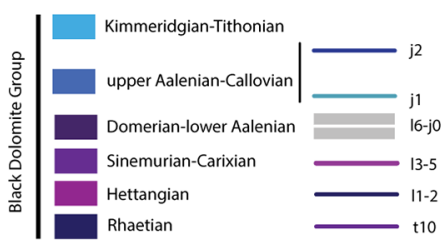

Keuper $\longrightarrow$ Keuper detachement

Muschelkalk (tM)

Permo-Buntsandstain ( $\mathrm{rt}$ )

Low grade metamorphosed basement

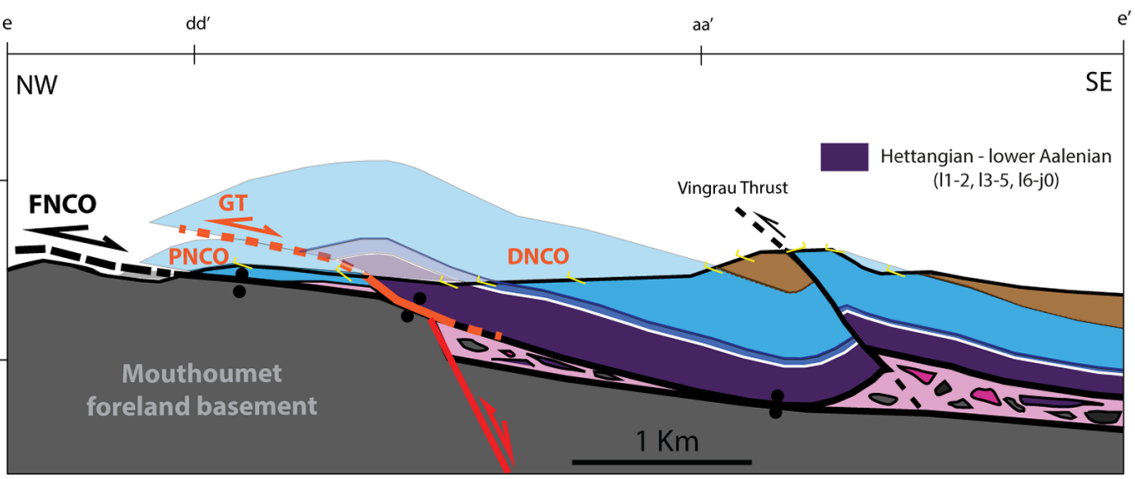


Fig. 8. (a) Interpreted Google Earth view of the Garrigas area, showing the NCO detached above the Mouthoumet basement and the DNCO thrusting the PNCO toward NW along the Garrigas Thrust. The DNCO and the PNCO strata present opposite orientation. (b) Field view toward the SW of the Garrigas unit detached above Mouthoumet basement showing the downward plunge of Malm strata onto flat top Keuper detachement. (c) NE-SW trending dd' cross-section of the Garrigas Jurassic rollover NW-SE oriented (map trace on Fig. 5) with a representation of the column 4 of the Figure 4. The tie points with section ee' is indicated. (d) the NW-SE trending ee' cross section (map trace on Fig. 5) showing the NCO detached above the Mouthoumet foreland basement, the DNCO thrusting the PNCO, and the NE termination of the Vingrau thrust and folds. The tie points with sections aa' and dd' is indicated.

NCO. It is affected by hypothetic Pyrenean N110 oriented normal faults. Here, we relate the formation of the Treilles Fault during the Jurassic to regional extension and subsidence accommodated on these N110 oriented basement faults but decoupled by Keuper salt (Fig. 14b).

Comparison of sections and their restoration indicates that the Treilles Fault records a significant post-Jurassic deformation as the passive tilt of its plane, gentle folding of its footwall and hanging wall, an additional post-Jurassic normal heave and the formation of secondary faults of different orientations. As the tilt of the fault and the tilt of top Jurassic in the hanging wall are equal (about $15^{\circ}$ ), we propose that these occur simultaneously, in association with the uplift of the hanging wall. This describes a post-Jurassic folding phase that we interpret as linked to Pyrenean orogenesis but without being able to clearly identify the timing within the orogenesis due to absence of syn-orogenic strata. Even if this could have initiated during early orogenesis, we propose to associate this folding phase to the NCO emplacement onto the Mouthoumet foreland. We propose that the post-Jurassic normal heave of the Treilles Fault ( $1 \mathrm{~km}$ on cc' section to $1.5 \mathrm{~km}$ on aa' section) developed after $\mathrm{NCO}$ emplacement during the Oligo-Miocene extension phase rather than during Apto-Cenomanian extension. A continuation of the functioning of the Treilles Fault during Early Cretaceous with a late additional Pyrenean folding would have tilted top Jurassic more (e.g. $45^{\circ}$ or more) than what is observed $\left(15^{\circ}\right.$, Fig. 6).

We interpret the presence of blocks of sub-salt strata in Keuper as a consequence of shear deformation at the base of Keuper detachment and the formation of a wide salt weld (plurikilometric, Fig. 6a) between basement and supra-salt strata constituting the NCO. We propose that the chaotic zone of dismembered Jurassic strata at the base of the Treilles Fault hanging wall (Figs. 6c and 7) has been created by shear deformation between the Keuper and Liassic Marls detachment levels during multiple deformation phases. This phenomenon has been amplified by the formation of salt welds between basement and supra-salt strata. The estimated original volume of Jurassic dismembered units is represented on restorations with high uncertainty (white hatched pattern on sections, Fig. 6a). The current chaotic nature of these lower units makes it difficult to discern if the fault was active before the upper Aalenian. However, in the Treilles Fault hanging wall (section aa', Fig. 6a), the Domerian-lower Aalenian increases in thickness consistently toward the Treilles Fault over $10 \mathrm{~km}(0 \mathrm{~m}$ in the Aguilar area, column 8 , to $200 \mathrm{~m}$ in Laval area, column 10, Figs. 2a and 4). Without rejecting the importance of the Domerian-lower Aalenian as a detachment level, we propose that this gradual variation over $10 \mathrm{~km}$ is more stratigraphic than tectonic in origin as previously proposed (Donnadieu, 1973; Lespinasse, 1965; Raymond, 1965; Vila, 1964), implying activity of the Treilles Fault during the Domerian-lower Aalenian.
The Boutine rollover and the Pied-du-Poul syncline document clear growth during at least the Aalenian-Callovian with units thickening from SW to NE in both the hanging wall and the footwall, with an immediate hanging wall thicker than the immediate footwall. Variations in thickness of the Kimmeridgian-Tithonian observed on the aa' section are clearly less important than those visible in the Domerian-lower Aalenian and the upper Aalenian-Callovian units (Fig. 6a), suggesting that displacement on the Treilles Fault may have decreased at this time. This observation cannot be confirmed on the cc' section (Fig. 7).

\subsection{The Garrigas unit}

The Garrigas unit (Figs. 5 and 8a) located at the SE edge of the Mouthoumet massif (PNCO, Zone A, Fig. 2a, b) has been considered by previous authors as a likely equivalent of the Fontjoncouse unit (PNCO, Zone C, Fig. 2a, b) (Berger et al., 1997; Raymond, 1965), witness of the prolongation of the PNCO at the SE edge of the Mouthoumet foreland basement. The interpreted views (Fig. 8b, location on Figs. 5 and $8 \mathrm{a}$ ) and the dd' (NE-SW oriented, Fig. 8d) and ee' (NW-SE oriented, Fig. 8d) cross-sections show this unit detached above the Mouthoumet massif, with local absence of Keuper at its NW front (Front of the NCO) and supposed absence below the unit. To the SE, the unit is overthrusted by the DNCO along the NESW trending Garrigas Thrust (Figs. 5 and 8a, d). The Garrigas unit consists of NE dipping Sinemurian to Tithonian strata that terminate downward onto the low angle top Keuper detachment (Fig. 8a-c). The dips decrease upward from $45^{\circ} \mathrm{NE}$ at the base of the upper Aalenian to $25^{\circ} \mathrm{NE}$ in the base of the Kimmeridgian describing a NW-SE trending upper AalenianKimmeridgian growth strata with a maximum thickness of over 500 m (Fig. 8a, c).

We interpret these growth strata in the Garrigas unit (Fig. 8b) as evidence of Jurassic strata thickening from SW to $\mathrm{NE}$, as is also observed in the DNCO along the N110 oriented Treilles Fault (Sect. 4.3). We underline that the same geometry between the NE dipping growth strata and the flat Keuper detachment is observed both in the small Garrigas unit $(500 \mathrm{~m})$ and in the larger Boutine unit $(2 \mathrm{~km}$, Fig. 6a, c). We therefore propose that the Garrigas unit could also correspond to a remanent, due to ante-NCO emplacement erosion, of a NW-SE oriented rollover anticline, that developed in the PNCO during the Jurassic (Garrigas rollover anticline) and that was inverted during Pyrenean orogenesis. The N110 oriented Jurassic structure expected to control the Garrigas rollover to the NE of the unit, remains unidentified due to erosion. During the NCO emplacement to the NW, local salt welds formed between the basement and the unit. At the same time, the Garrigas Thrust developed between the Garrigas unit and the DNCO. 

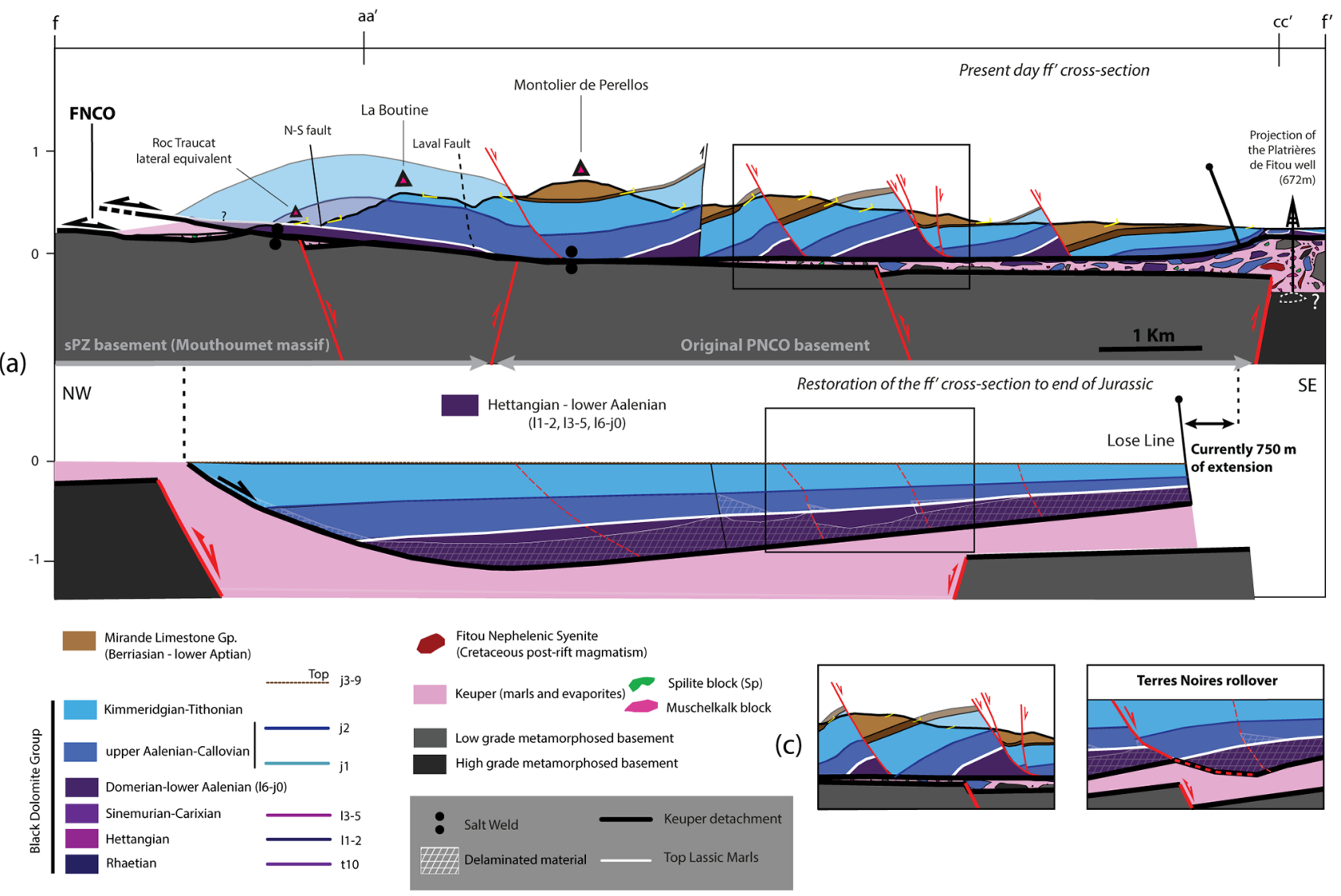

(b)
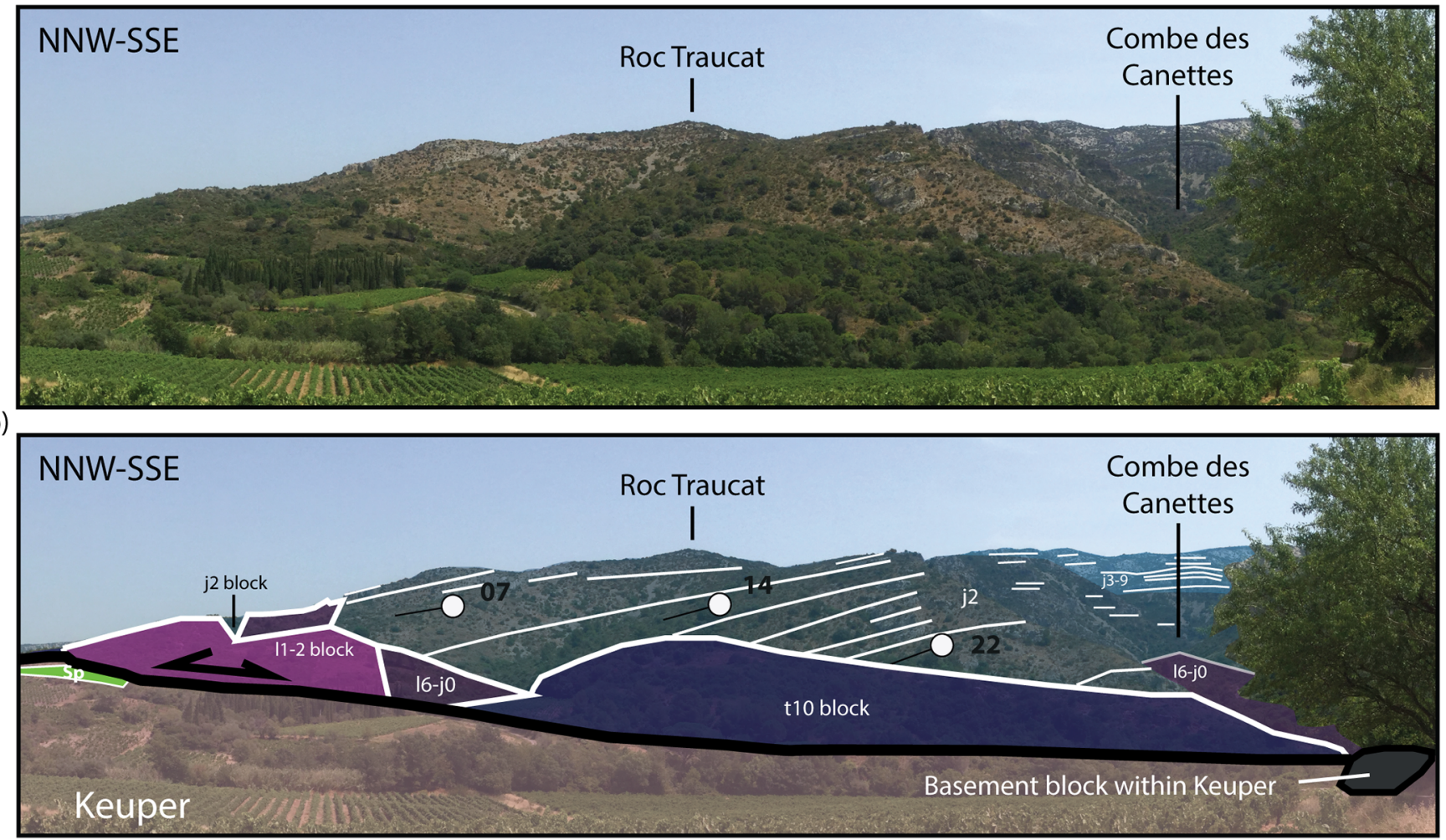
Fig. 9. (a) Top: present-day NW-SE trending ff' cross-section (map trace on Fig. 5). The tie points with sections aa' and cc' are indicated. This section shows the DNCO emplaced over the Mouthoumet massif. It also shows the Boutine-Roc Traucat inverted rollover, and the segmentation of the DNCO in a series of NE-SW trending fault blocks whose strata truncate downward onto Liassic Marls and Keuper detachments. Bottom: restoration of section ff' to end of Jurassic showing the thin skinned extension of the supra-salt cover decoupled from basement Cevenole faulting along the Keuper evaporites. The lateral equivalent to the SW of the Terres Noires fold pair (Figs. 5, 10a and 13a, b) is framed in black on both present day and restored sections. (b) Uninterpreted and interpreted ENE-ward field view of the Roc Traucat growth strata (Fig. 5a). Blocks of sub- and supra-salt strata lie along the Keuper and Lias Marls detachment levels. (c) Zooms of the lateral equivalent to the SW of the Terres Noires fold pair (framed in black in (a)), showing the activity of NE-SW oriented normal faults within the DNCO during the Jurassic that is demonstrated with the Terres Noires fold pair study (Sect. 4.9, Figs. 5, 10a and 13a, b).

\subsection{The NE-SW oriented Garrigas Thrust}

Previous authors have proposed that the PNCO and the DNCO were separated by a NW verging thrust during Pyrenean orogenesis (Berger et al., 1997; Viallard, 1987). It has been proposed that in the north-eastern part of the Corbières Virgation this thrust was partially negatively inverted during the Oligo-Miocene to form the Narbonne normal fault (Berger et al., 1997; Gorini et al., 1991) (Figs. 2a, c). At the SE edge of Mouthoumet, this thrust is supposed to correspond to the Garrigas Thrust (Figs. 5 and 8a, d; Berger et al., 1997; Raymond, 1965). Our stratigraphic correlation (Fig. 4) shows clear Jurassic thickness variations between the PNCO and the DNCO, suggesting that the structure limiting both could itself be inherited from a Jurassic rift feature. This is also suggested by Gorini et al. (1991) who identified a salt diapir at Portel-des-Corbières (DNCO, Fig. 2a, c) that they supposed to have functioned along the Narbonne fault from the Jurassic on, piercing to the surface in the Cretaceous and Oligo-Miocene. We here investigate the DNCO along the NWSE trending ff' section (Fig. 9a) to identify geometric variations of Jurassic strata in relation to this hypothetic rift feature. For the purpose of the paper we named this structure the Garrigas-Narbonne Fault (GNF) as represented on the Figures $2 \mathrm{~b}$ and $2 \mathrm{c}$. We use the term Garrigas Thrust (GT) to name the GNF portion along the Treilles Fault hanging wall. The term Narbonne Fault (NF) is use to name the GNF portion along the Treilles Fault footwall.

The present day ff' section (Fig. 9a) crosses the SE edge of the Mouthoumet massif and the Treilles Fault hanging wall (DNCO) close to the Treilles Fault map trace. The PNCO and the Garrigas Thrust are here eroded. The ff' section orthogonally intersects section aa' (Fig. 6a) in the Boutine area and the cc' section (Fig. 7) close to the Paltrières de Fitou well (Fig. 5), providing control points for depth to top Keuper and top basement as well as for Jurassic thickness. Along the rest of the ff' section the depth to top Keuper is projected laterally from the NE, parallel to the dip of the Treilles Fault. The section shows the DNCO emplaced onto the $\mathrm{N} 110^{\circ}$ trending Mouthoumet basement anticline which is represented to continue down plunge toward SE below the DNCO. The Mouthoumet anticline is here affected by hypothetic NE-SW trending Cévennes faults which show both Pyrenean reverse and Oligo-Miocene normal displacements. Above salt, the section is dominated by fault blocks of Jurassic to Neocomian strata limited by NE-SW trending normal faults dipping SE and one high angle reverse fault dipping NW (Fig. 9a). The Kimmeridgian-Tithonian to Neocomian strata dip toward the NW except in the common flank of the only fold pair of the section (Boutine Anticline and Montolier de Perellos
Syncline; Fig. 9a), where beds dip shallowly SE (stereoplot of bedding poles, Fig. 5). The section incorporates the key observation that beds in these fault blocks truncate downward onto top Keuper, as it is clearly visible on the southern margin of the Feuilla half-window and the Treilles and La Marende windows (Figs. 5 and 10a, b). Overall the upper AalenianTithonian units thicken from the Fitou area (SE of the section) to the Boutine area (NW of the section), with NW-ward thickening of the Kimmeridgian-Tithonian on the $\mathrm{ff}$ ' restoration that is more important than its NE-ward thickening on the aa' restoration (Fig. 6a). On the north-western flank of the Boutine anticline, the upper Aalenian-Callovian beds dip NW to terminate down Liassic Marls detachments that lies above the Keuper detachment, with a dip fan decreasing upward from $22^{\circ}$ to $07^{\circ} \mathrm{NW}$ observed in the Roc Traucat massif (Fig. 9b), describing an upper Aalenian-Callovian growth strata (Boutine-Roc Traucat growth strata). The chaotic zone of dismembered blocks of the Boutine area described above (Sect. 4.1), in relation to the Liassic Marls and top Keuper detachments, is also observed on the field view of the Figure 9b.

\subsection{Interpretation of the Garrigas Thrust}

Our study presents for the first time evidence (thickness variations and growth strata) of Jurassic syn-sedimentary folding in the hanging wall of the NE-SW oriented Garrigas Thrust. Based on the restoration to end of Jurassic of the ff' section (Fig. 9a), we propose that during the Jurassic, a rollover anticline NE-SW oriented (Boutine-Roc Traucat rollover, Figs. 6a, c and 8d), formed in relation to an extensional structure with the same orientation that developped between the PNCO and the DNCO. To the upper-Aalenian-Callovian activity of this extensional structure, we associate the deposition of the Feuilla Fm. (part of j1 map code; Figs. 3 and 4) in the DNCO in contrast to the PNCO and the SPZ where this formation is absent (e.g. Fig. 8a).

We propose that the ff' section experienced a strong postJurassic deformation as recorded by the uplift and folding of the supra-salt cover and the formation of reverse and normal faults. Due to these post-Jurassic deformations and erosion (absence of the PNCO and the Garrigas Thrust on the ff' section and absence of part of the hanging wall on the ee' section), the relation during the Jurassic between the PNCO and the DNCO as well as the nature of the extensional structure between them remain unidentified. The observation on sections dd' and ee' of different orientations between the Garrigas Thrust immediate footwall (Garrigas inverted rollover, N110 oriented) and the immediate hanging wall 

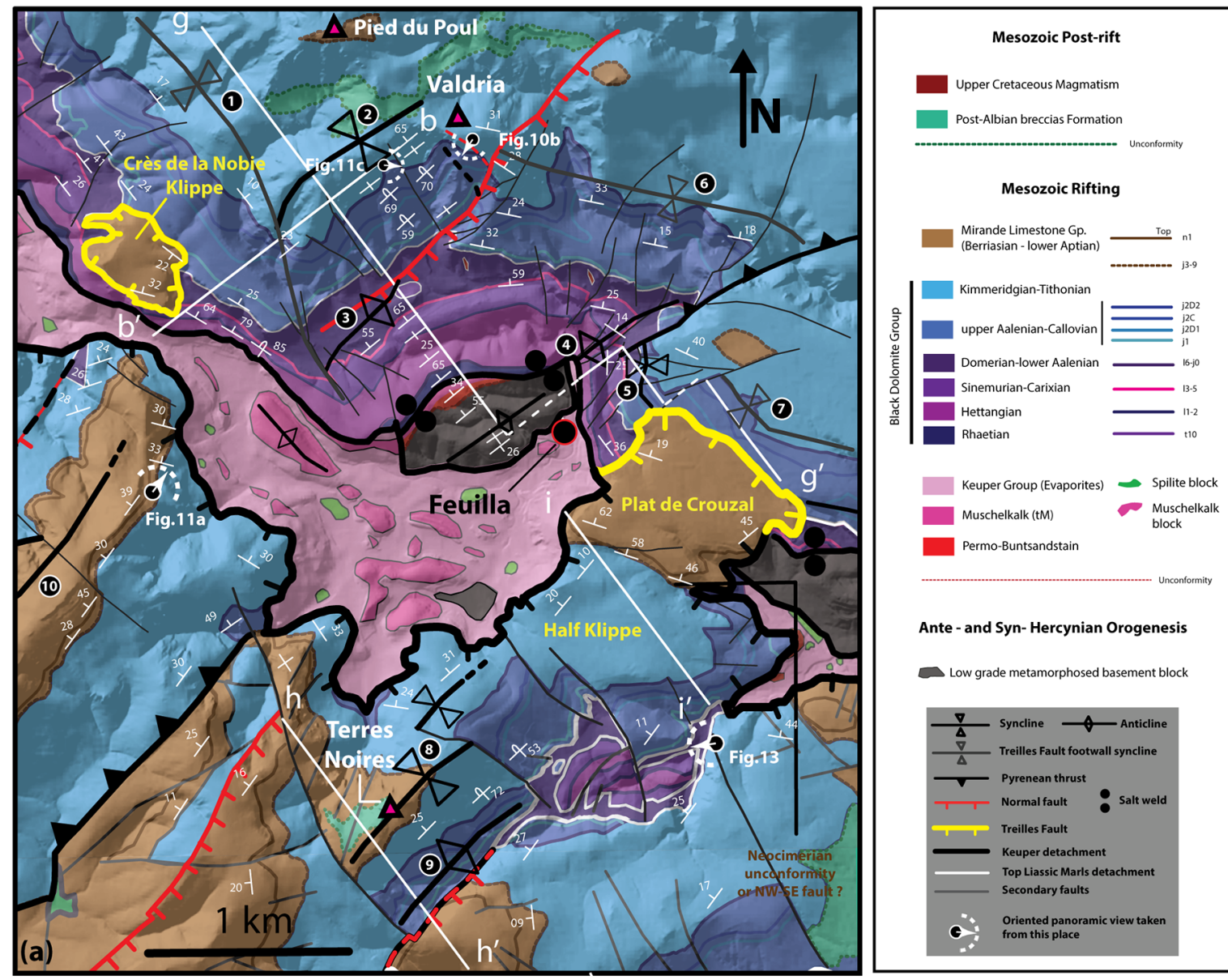

Ante - and Syn- Hercynian Orogenesis

Low grade metamorphosed basement block
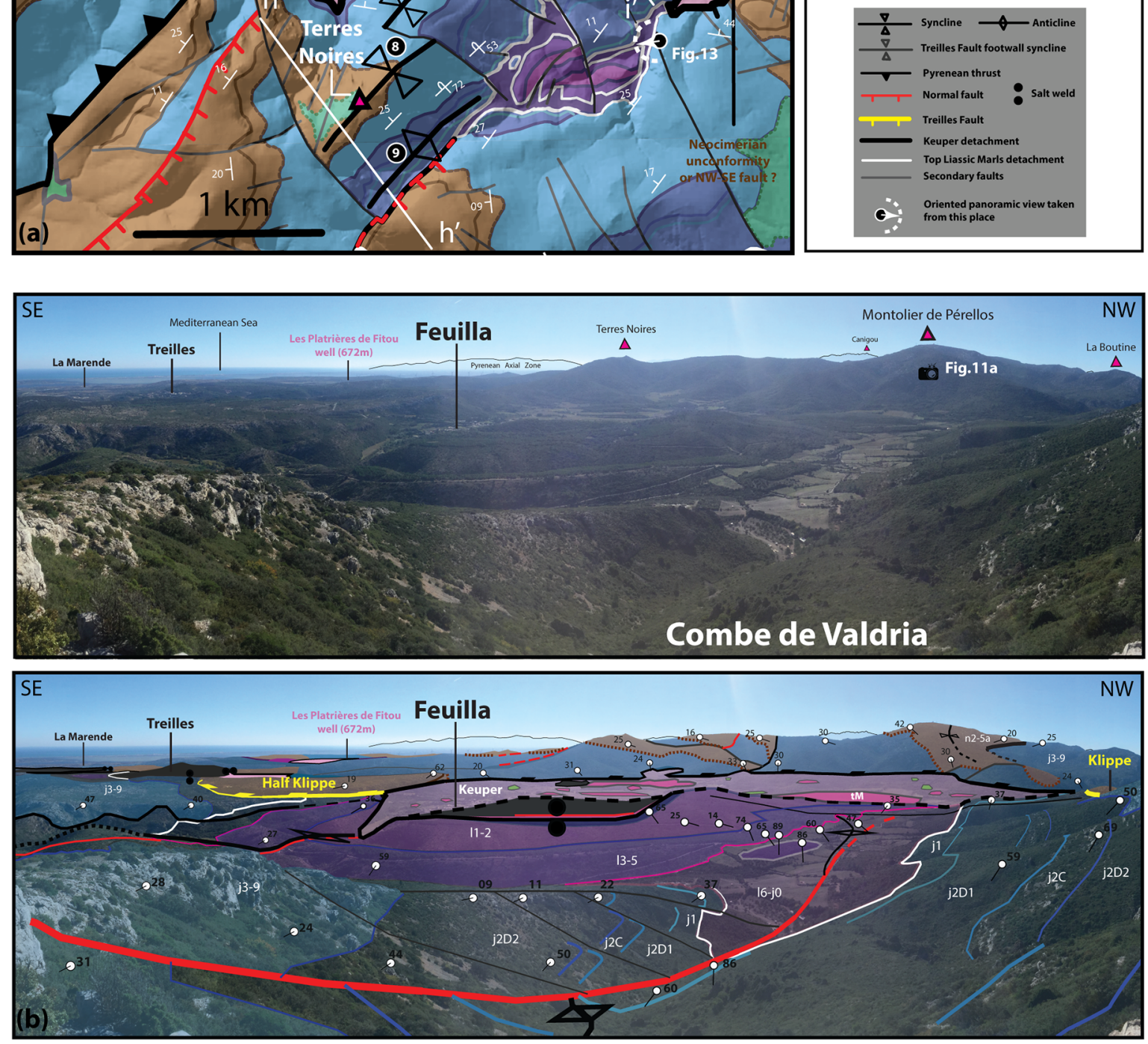
Fig. 10. (a) Geological map of the Feuilla half-window showing the map trace of sections bb', gg', hh' and ii' and location of the field views in Figures $10 \mathrm{~b}$ and 11a, b. Folds are identified by a number, 1: Pied-du-Poul TF footwall growth syncline; 2: Valdria syncline; 3: Valdria anticline; 4: Feuilla anticline; 5: Feuilla syncline; 6: Mezerac TF (Treilles Fault) footwall growth syncline; 7: Plat du Castel TF footwall growth syncline; 8: Terre Noires syncline; 9: Terres Noires anticline; 10: Montolier de Perellos sycnline. (b) Uninterpreted and interpreted SW field view of the Feuilla half-window showing the rotation of the Jurassic strata of the DNCO above and below the subhorizontal Treilles normal fault. In the foreground is the footwall of the fault with the Valdria inverted common limb visible in the upper Aalenian-Kimmeridgian units (right corner of the view). In the background is the Treilles fault hanging wall where the downward truncation of strata in faulted blocks can be seen.

(DNCO, NE-SW oriented) (Fig. 8a) leads us to hypothecally represent on the ff' restoration model (Fig. 9a), the BoutineRoc Traucat rollover to develop during the Jurassic along the SE flank of a NE-SW oriented salt wall (Jackson and Hudec, 2017) that dips $20^{\circ}$ SE. The PNCO would have developed along the NW flank and the salt wall would have reached the surface between these two zones (see block diagram Fig. 14b). In this case the Garrigas Thrust would be a thrust weld corresponding to a squeezed Jurassic salt wall (Jackson and Hudec, 2017). Another possibility is that a $20^{\circ} \mathrm{SE}$ dipping normal fault developed between the PNCO and the DNCO. In this case the Garrigas Thrust would correspond to an inverted Jurassic normal fault. In both cases the necessary accommodation is supposed to be created by unidentified basement cutting normal faults but decoupled by Keuper evaporites, as represented on the block diagram and associated zoom (Fig. 14b).

Although the supra-salt cover experienced compression, it is currently in net extension on the ff' section (750 m, Fig. 9a). As for the aa' restoration, the estimated original volume of dismembered units between the Keuper and Liassic Marls detachments is represented with high uncertainty on the ff' restoration (hatched part in white on ff' restoration, Fig. 6a). The basement represented on the restoration corresponds to the original autochtonous basement below the Jurassic basins before the emplacement of the NCO to the NW-NNW (Fig. 14). It is affected by Cévenoles normal faults oriented NE-SW. We propose here to relate the formation of the extensional structure (GNF, Garrigas-Narbonne Fault or GNSW, Garrigas-Narbonne Salt Wall) developed between the PNCO and the DNCO during the Jurassic to regional extension and subsidence accommodated on Cévenoles basement faults but decoupled on Keuper salt (Fig. 14b).

The comparison of the aa' section (Fig. 6a) and the ff' section (Fig. 9a), around their intersection (Boutine area) leads us to propose the existence of domal structure of which the axis curves from NW-SE (Fig. 6a) to NE-SW (Fig. 9a). We interpret this domal structure as a 3D rollover anticline devoloped during the Jurassic and that have been folded and uplifted during the Pyrenean orogenesis (3D Boutine inverted rollover). The current apparent dip of the top Keuper below the inverted rollover on the aa' and ff' sections suggests that the N110 oriented Treilles Fault passes in continuity to the NE-SW oriented Garrigas Thrust. As shown in the block diagram (Fig. 14b), aa' and cc' restorations to end of Jurassic show the original 3D low dip (around $20^{\circ}$ ) of this 3D linkage zone between both oblique structures.

As for section aa', we interpret the chaotic zone of dismembered sub- and supra-Keuper units to be linked to the intense shear deformation on the linked Keuper and Liassic Marls detachment levels during extensional and compressional events. On the ff' section, the fact that an important part of the basal Jurassic succession is missing in each fault block implies that this material was removed during or after the activity of the NE-SW oriented normal faults. As these faults clearly displace Jurassic to Neocomian strata, they could have been active during the Jurassic to Neocomian and/or after the Neocomian. The activity of these faults during the Jurassic (e.g. Fig. 9b) is suggested below (Sects. 4.6-4.9). Considering this, the fact that the ff' section is currently in net extension (750 m, Fig. 9a) while the section has experienced Pyrenean compression implies two possibilities. First, the NE-SE oriented normal faults are Jurassic to Early Cretaceous in age, suggesting that they were not inverted (or partially) during the folding of the Boutine-Roc Traucat rollover. In this case the basal delamination of each fault block (Fig. 9a) is related to the NCO emplacement. The second possibility is that the NE-SW normal faults could have a part of their activity that is post-NCO emplacement in age (Chattian-Burdigalian). In this case the basal delamination of each fault block could developed in two stages, initially during the NCO emplacement, and secondly after NCO emplacement, during the Gulf of Lion extension phase and in association to the post-Jurassic normal heave of the Treilles fault suggested in the Section 4.2.

The proposed chronology of deformation for the $\mathrm{ff}^{\prime}$ section, would therefore be (1) Deposition of the Jurassic succession controlled by a NE-SW thin skinned normal fault or a salt wall (e.g. salt ridge) between the PNCO and the DNCO. Probable formation of other NE-SW oriented normal faults within the DNCO (see Sects. 4.8 and 4.9). The extension in supra-salt cover was triggered by basement extension along normal faults but decoupled by Keuper evaporites (2) Possible continuation of activity on supra-salt structures during the Neocomian to Apto-Cenomanian, except between the PNCO and the DNCO due to our interpretation of the 3D Boutine-Roc Traucat domal structure as an inverted Jurassic rollover (3) folding and uplifting of the Jurassic rollover anticline during Pyrenean compression and $\mathrm{NCO}$ emplacement onto the Mouthoumet foreland (basement already stripped at this time) associated with basal delamination (4) possible Oligo-Miocene activity of the NE-SW oriented supra-salt faults associated to late Treilles Fault activity and basal delamination of the NCO.

\subsection{The Valdria fold pair}

On the northern margin of the Feuilla half-window, the Jurassic series of the Treilles Fault footwall are affected by a N110 trending Jurassic growth syncline (corresponding to folds 1, 6 and 7, Fig. 10a) but also by two NE-SW trending fold pairs (two syncline-anticline pairs), forming a complex fold interference map pattern (Figs. 10 and 11a). These fold pairs 
(a)

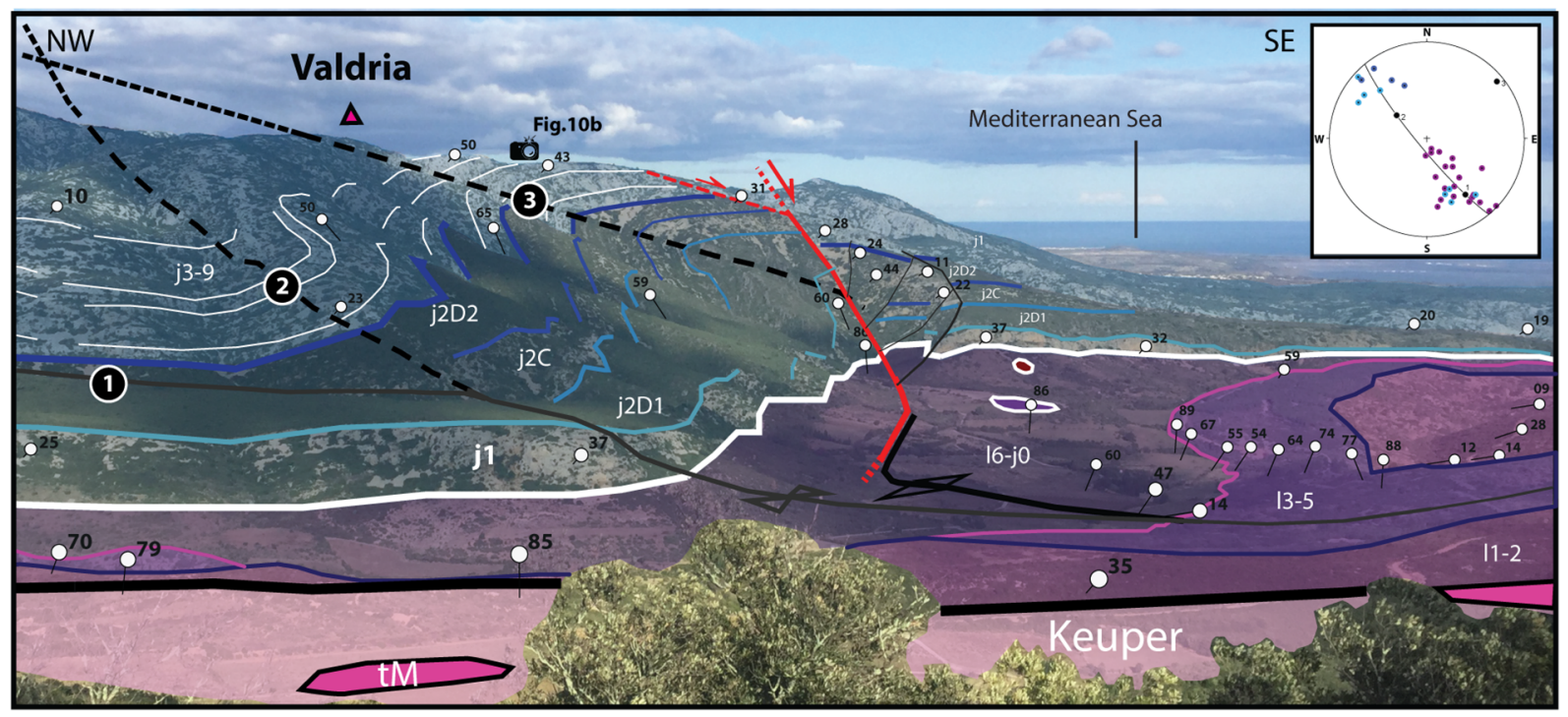

(b)
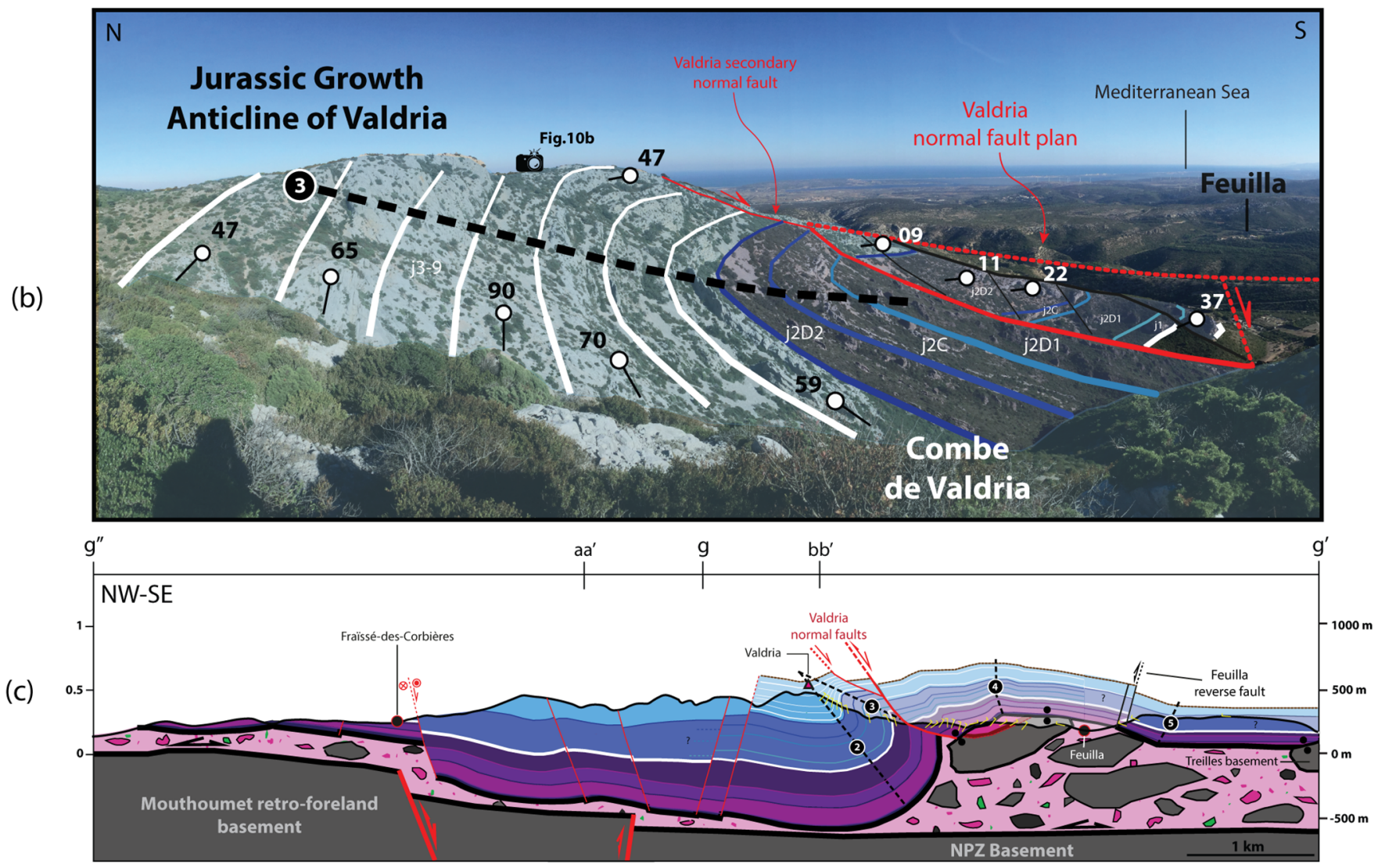

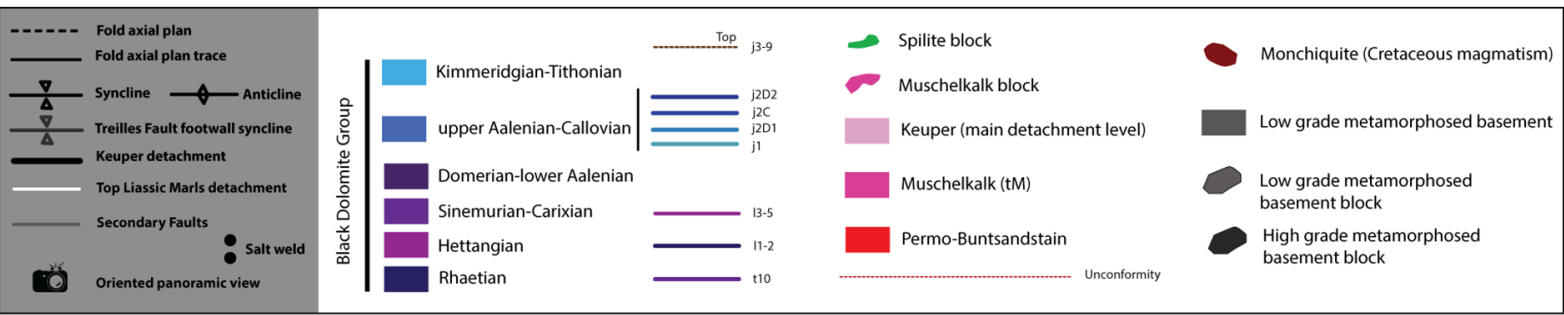


Fig. 11. (a) Interpreted NE-ward field view of the Valdria fold pair in the NW part of the Feuilla half-window showing the thickness variation of the upper Aalenian-Callovian across the Valdria anticline and the thickenning of the j2D2 terme across the Valdria normal fault. Stereoplot of poles to Jurassic bedding along the gg' section from the basement inlier to the Valdria massif. The colours of poles refer to their stratigraphic unit (see legend of the figure) except for Liassic poles which have the same color (purple). The numbers 1 to 3 on the stereoplot are statistically derived eigenvectors with point 3 representing the pi pole. (b) Interpreted eastward field view of the Valdria anticlinal hinge zone showing Kimmeridgian-Tithonian growth strata. (c) NW-SE g"g' cross-section of the Valdria and Feuilla fold pairs (map trace on Fig. 5). Folds are identified by a number, 2: Valdria syncline; 3: Valdria anticline; 4: Feuilla anticline; 5: Feuilla syncline.

named the Valdria (folds 2 and 3, Fig. 10a) and Feuilla (folds 4 and 5, Fig. 10a) fold pairs, are here described along the NW-SE oriented g"g' cross-section between Fraïssé-des-Corbières at the NW end to the footwall of the Plat de Crouzal half-klippe at the SE end (Figs. 2a and 11c). Only the trace of the gg' portion of the section is represented on the map of Figure 10a.

The Valdria and the Feuilla fold pairs both present a strike length of about $1 \mathrm{~km}$. The Valdria fold pair, shows NW vergence and an inverted common limb $\left(60-70^{\circ} \mathrm{NE}\right.$ average dip) cut by sub-vertical faults oriented NW-SE. The Feuilla syncline shows E vergence on the Figure 10a (SE apparent vergence on the g"g' section, Fig. 11c) while Feuilla anticline presents a vertical axial plane. The Feuilla basement inlier lies in the core of the Feuilla anticline (here eroded) and is folded like the supra-salt cover but with an axial plane shifted $200 \mathrm{~m}$ toward SE (Fig. 10a). On the northern flank of the inlier, Paleozoic strata are unconformably overlain by the Upper Permian-Buntsandstein and the Muschelkalk units. The Keuper evaporites are missing between the Muschelkalk and the overlying Rhaetian unit (Figs. 10a and 11c). On its southern and western flank, the basement inlier is in direct contact with allochthonous Keuper. Each fold pair is affected by a fault oriented NE-SW. The Valdria normal fault cuts the Valdria anticline, downthrowing to the SE, while the Feuilla reverse fault cuts the Feuilla syncline with a SE vergence. Both faults die out toward the Treilles Fault. We note that a small footwall normal fault dipping $15-20^{\circ} \mathrm{SE}$ branches onto the Valdria Fault (Figs. 10a and 11a, b) and will be discussed below.

Along the gg' section, the Jurassic series is observed to have a maximum thickness $(1200 \mathrm{~m})$ in the Valdria syncline hinge and to thin to the SE by $50-70 \%$ toward and across the Valdria anticlinal hinge. The minimum thickness is observed in the Feuilla syncline $(300 \mathrm{~m})$. On the Valdria inverted common limb, Kimmerdgian-Tithonian strata show a dip fan from overturned $60-70^{\circ} \mathrm{SE}$ to $55^{\circ} \mathrm{NW}$ (Fig. 11a, b). Older units (upper Aalenian-Callovian) are consistently overturned with dips generally around $60^{\circ} \mathrm{SE}$. These thickness and dip variations clearly indicate that these are Jurassic growth strata. We note that the $\mathrm{j} 2 \mathrm{D} 2$ term of the upper Aalenian-Callovian unit (Fig. 3) thickens across the Valdria normal fault from its footwall $(35 \mathrm{~m})$ toward its hanging wall $(85 \mathrm{~m})$ (Figs. 10a and 11a, b), it then thins gradually towards the SE along with the rest the upper Aalenian-Callovian across the Feuilla fold pair, over a distance of $2 \mathrm{~km}$. NW of the basement inlier, in the Valdria Fault hanging wall, the dip variations in the Rhaetian to Domerian indicate secondary folding within the Feuilla anticline (Figs. 10a and 11a, b).

\subsection{Interpretation of the Valdria fold pair}

Donnadieu (1973) proposed that the Valdria and Feuilla fold pairs (Fig. 11c) were formed during the Pyrenean orogeny. Our study instead shows that these developed during a more complex history, by presenting for the first time data that demonstrate NE-SW oriented Jurassic syn-sedimentary folding (growth strata). We present here a five stage schematic restoration model (Fig. 12) of the Valdria fold pair (section gg', Fig. 11c). In this model, the fold pair is interpreted as a Jurassic forced fold that developed in the hanging wall of a NW dipping normal fault cutting sub-salt basement, similar to those described in the North Sea (Lewis et al., 2013; Withjack et al., 1990) and the Rhine Graben (Ford et al., 2007).

We propose that initial Jurassic folding tilts the Rhaetian (first supra-salt strata) by $20^{\circ} \mathrm{NW}$ during the Lias and by a further $20^{\circ} \mathrm{NW}$ during the Dogger. The Valdria Fault (Figs. $10 \mathrm{a}$ and 11c) formed during deposition of the j2D2 term of the upper Aalenian-Callovian unit (Fig. 3), close and parallel to the Valdria anticline axial plane, with a minor normal displacement $(50 \mathrm{~m})$. During deposition of the KimmeridgianTithonian, the Rhaetian to Callovian strata are further tilted by $20^{\circ} \mathrm{NW}$ and the Valdria normal fault is sealed (Fig. 12). The Valdria forced fold pair is represented on the block diagram (Fig. 14b).We propose that at the beginning of the NCO emplacement, a footwall shortcut thrust detaches part of the basement fault block crest which is transported at the base of the NCO. The local indentation of the basement block against the supra-salt-cover leads to (1) the formation of a salt weld between the block and the overlying supra-salt strata, (2) a minor positive reactivation of the Valdria fault $(50 \mathrm{~m}$, minimum displacement) (3) the formation of the Feuilla fault and fold pair (1 km of map length) in the SE limb of the Valdria anticline (4) the folding of the basement inlier strata like those of the supra-salt cover (Feuilla anticline), (5) the NW-SE tightening over $1 \mathrm{~km}$ of the Valdria Jurassic fold pair, with the overturning of the common steep limb by some $40^{\circ} \mathrm{NW}$ ( $300 \mathrm{~m}$ of shortening). This interpretation implies that the original Jurassic fold pair of Valdria could extend toward the NE.

Alternatively, the Feuilla fold pair could have formed passively between the Jurassic and Pyrenean orogenesis. Salt movement could have led to the molding of the supra-salt cover onto the tilted basement block (basement cutting fault necessarily shifted toward the NW, Fig. 12, frame in yellow). In this case, the gentle inversion of the Valdria fault and the formation of the Feuilla reverse fault could occured at this time. Only the stage (5) occured during Pyrenean orogenesis.

Finally, we interpret the post-j2D2 normal displacement along the the Valdria Fault as a later negative reactivation of 


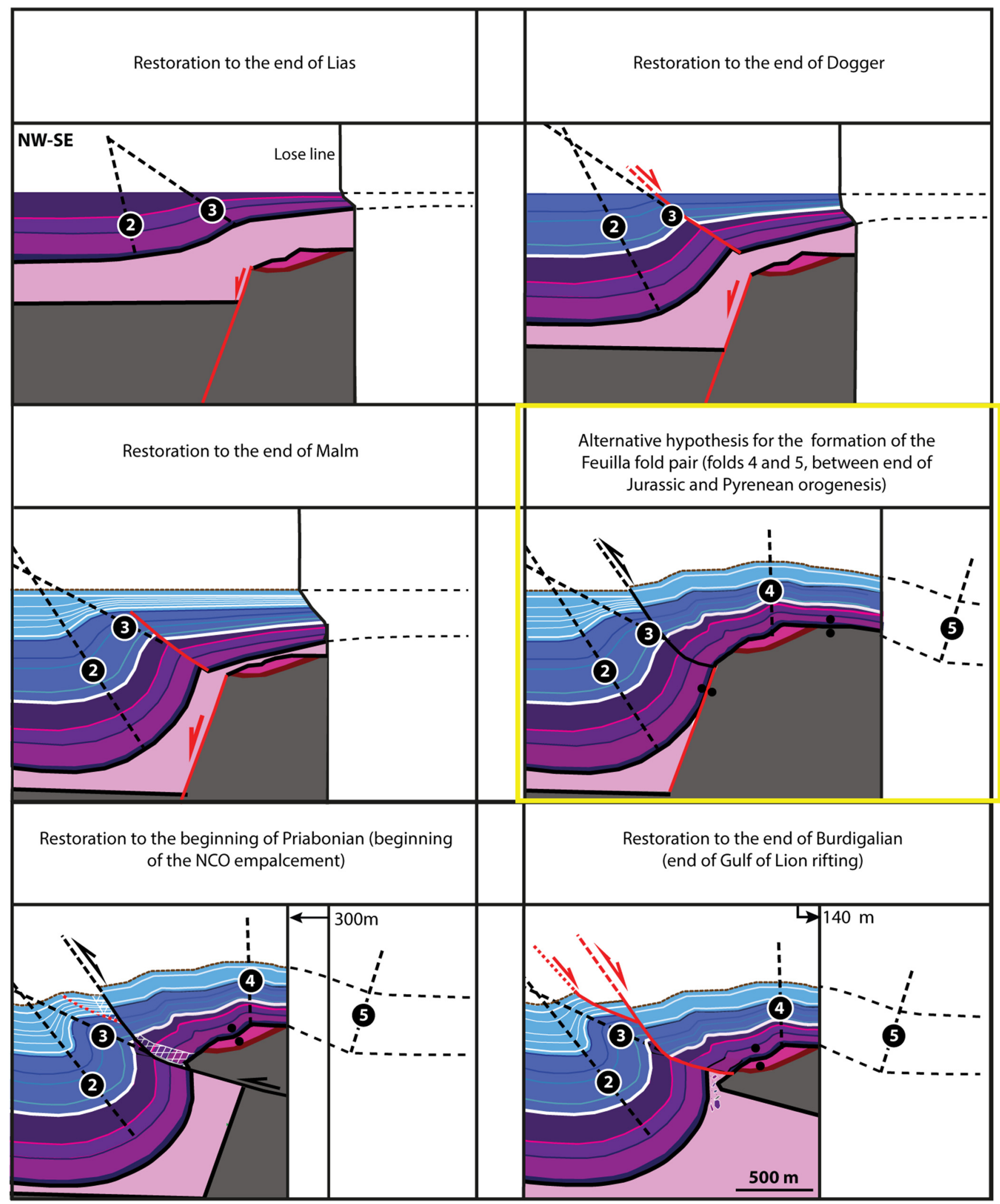

Fig. 12. Sequential restoration of the Valdria fold pair (gg' cross-section, Fig. 11c) interpreted as a Jurassic extensional growth fold that developed in the hanging wall of a NW dipping normal fault cutting subsalt basement. The fold pair was later reactivated during Pyrenean emplacement of the NCO and again during the Oligo-Miocene extension. During NCO emplacement, the nappe detached a block from the basement high (responsable of the overturning of the Valdria fold pair) which was transported along with the NCO. 


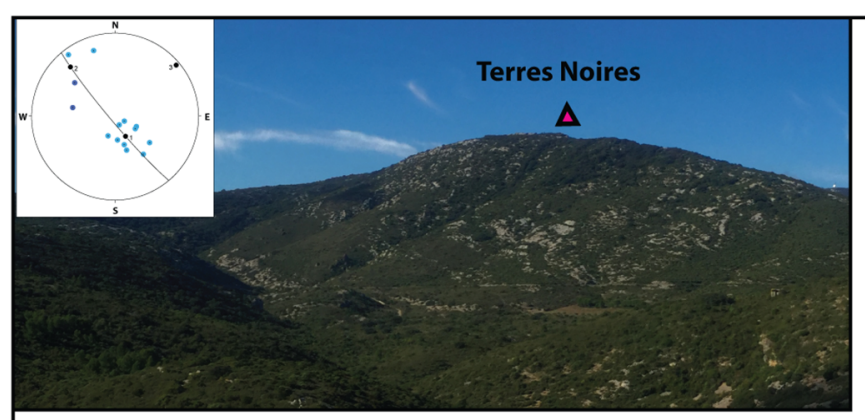

(c)

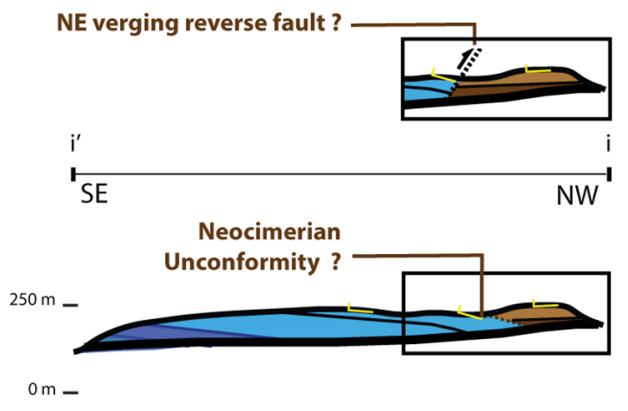

(a)

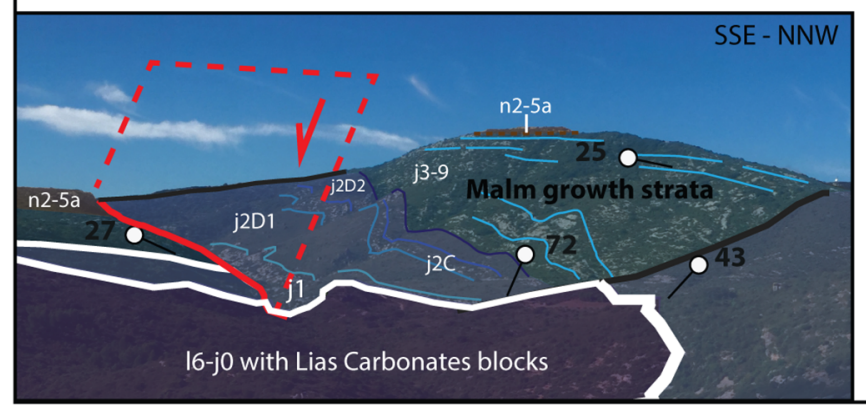

(b)

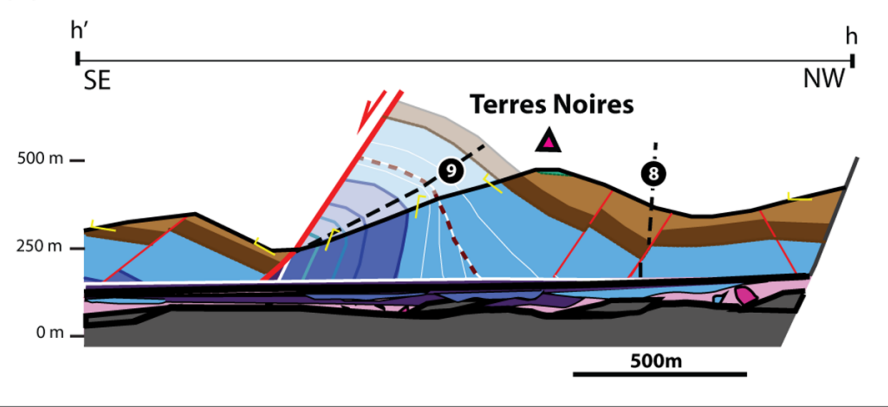

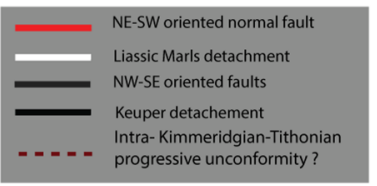
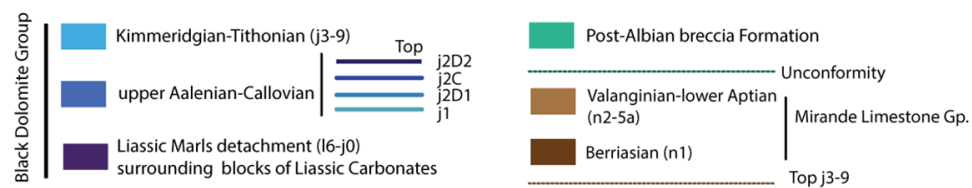

Keuper Group (Evaporites, Upper Trias)

Fig. 13. (a) Uninterpreted and interpreted SW field view of the Terres Noires massif with the steroplot of poles to Jurassic bedding of the Terres Noires Jurassic fold pair. (b) NW-SE oriented hh' cross-section of the Terres Noires fold pair, interpreted as a Jurassic inverted rollover (map trace on Fig. 10a). (c) NW-SE oriented ii' section of the Plat de Crouzal half-klippe (map trace on Fig. 10a). Two hypotheses are presented for the contact between Neocomian and Jurassic units either as thrust fault (above) or an unconformity (below).

the fault (140 m, minimum displacement) linked to the OligoMiocene rifting. The small normal fault in the footwall of the Valdria fault would have formed at this time.

\subsection{The Terres Noires fold pair}

In the hanging wall of the Treilles Fault, at the level of the SW part of the Plat du Crouzal half-klippe (SE of the Feuilla half-window, Fig. 10), the orientation of the Jurassic strata turns rapidly, changing from WNW-ESE trends to NE-SW. In this area the Jurassic to Neocomian strata are affected by the Terres Noires fold pair (Donnadieu, 1973; Figs. 10a and 13a, b), very similar in geometry and scale to the Valdria fold pair (Figs. 10a and 11). The Terres Noires fold pair is NE-SW oriented, it faces towards the NW and has a map length of $1.5 \mathrm{~km}$. This fold pair is, however, severely faulted, including strong basal delamination of the Jurassic strata and a steeply SE dipping normal fault abutted against Keuper, which cuts the anticlinal hinge and rotates to the SW to a steep NW dip (Figs. 10a and 13b). We cannot therefore fully reconstruct stratal geometries of these folds. Laterally, the Terres Noires fold pair is limited by steeply dipping NW-SE faults which also compartmentalize the Plat de Crouzal half-klippe, smaller similar faults also affect the common limb of the Valdria fold pair (Fig. 10a). In the NE part of the Plat du Crouzal half-klippe, upper Aalenian to Tithonian units with an average dip of $20^{\circ} \mathrm{NW}$ are mapped as unconformably overlain by the Berriasian and Neocomian whose beds terminate downward onto the Treilles Fault with a dip from 50 to $20^{\circ} \mathrm{NE}$ (ii' section, Figs. $10 \mathrm{a}$ and $13 \mathrm{c}$ ).

On the NW-SE oriented hh' cross-section (Fig. 13b) the geometry suggests that upper Aalenian-Tithonian series have a maximum thickness in the common limb of the Terres Noires fold pair and thins to the SE by $50-70 \%$ toward and across the anticlinal hinge and the NE-SW normal fault to the SE. On the inverted common limb, Kimmeridgian-Tithonian strata show a dip fan from overturned $\left(70^{\circ} \mathrm{SE}\right)$ to $25^{\circ} \mathrm{NW}$ (Figs. 10a and $13 \mathrm{a}, \mathrm{b})$. This evidence indicates that, like the Valdria fold pair, the Terres Noires folds comprise Jurassic growth strata.

\subsection{Interpretation of the Terres Noires fold pair}

Donnadieu (1973) suggested that the Terres Noires fold pair (Figs. 10a and 13a, b) was formed during the Pyrenean orogeny. As for the Valdria fold pair (Figs. 10a and 11c), our study instead shows that these folds developed during a more complex history initiated in Jurassic time. Although limited, most observations indicate that these folds evolved in the same manner and with the same timing as the Valdria fold pair, with Jurassic growth folding, Pyrenean tightening and Oligo-Miocene extension. The main difference between the two fold pairs being that they are not on the same side of the 
Treilles Fault. As the Terres Noires fold pair lies in the immediate hanging wall of the fault, it cannot have functioned as a forced fold during the Jurassic in contrast to the Valdria fold pair. To explain the formation during the Jurassic of the NE-SW oriented Terres Noires growth fold in the immediate hanging wall of the N110 Treilles Fault, we invoke the activity of a NE-SW normal fault with a SE vergence, along the NW border of the Plat de Crouzal half-klippe. This fault would have locally formed an extensionnal rollover anticline (Terres Noires rollover) during the Jurassic (Fig. 9c). Even if this is not observed neither in Valdria nor in Terres Noires, we here suggest that a progressive growth unconformity could have formed to accommodate the rapid dip change observed over a short distance $(150-200 \mathrm{~m})$ in the Kimmeridgian-Tithonian unit of Terres Noires common limb (burgundy dash line, Fig. 13b).

We interpret the abrupt structural and stratigraphic changes and the dying out of the Jurassic fold pair from SW to NW across the NW-SE faults as linked to a Jurassic activity of these faults (Fig. 10a). However, as the NW-SE fault, limiting the fold pair to the SW, cuts Neocomian strata, these NW-SE faults record a more complex activity. We propose that theses faults were active during the Pyrenean tightening to limit lateraly the overturning of the common limb NE-SW oriented. In this way, we suggest that in the NE part of the Plat de Crouzal halfklippe, the mapped unconformity at the base of the Neocomian (Berger et al., 1982) could be a NW-SE fault as we didn't find any field evidence to confirm it as an unconformity (see both hypothesis on Fig. 13c). The similar geometry, orientation and map lenght between the Valdria and Terres Noires inverted limbs, lead us to suggest that the very spatially limited overturning of the Terre Noires common limb, could also be linked to the indentation of a basement block (different than this of Feuilla) against the supra-salt strata as suggested by Donnadieu (1973). This basement block could have been removed during NCO transport and the basal delamination of the Treilles Fault hanging wall. This interpretation implies that the original Jurassic rollover of Terres Noires could extend toward the SW (Fig. 9c), as the Valdria Jurassic fold pair could extend to the NE. Finaly, the fold pair was affected by the normal fault that cut the anticline. The activity of this fault from Jurassic to orogenic phases remaining unknown.

\section{Discussion}

\subsection{Evidence of a Jurassic decoupled extension}

An increasing volume of work documents the mobilization of Keuper evaporites from early Jurassic and throughout the Alpine cycle in and around western Mediterranean orogenic belts (e.g. Célini et al., 2020; Espurt et al., 2019a, 2019b; Ford and Vergés 2021; Graham et al., 2012; Labaume and Teixell, 2020; Vergés et al., 2020). The Corbières-Languedoc Transfer Zone has long been recognized as an area with significant volumes of Keuper evaporites at surface and at depth (Berger et al., 1982, 1993, 1997; Ellenberger et al., 1987; Lespinasse et al., 1982). Many Keuper salt related structures have been identified in the transfer zone. The most important being the Nappe des Corbières Orientales with its thin skinned thrusting style clearly linked to the Keuper detachment (Barnolas and Courbouleix, 2001). More local structures have also been recognized. Gorini et al. (1991) identified the thinskined Narbonne inverted fault and associated rollover and diapir (diapir of Portel-des-Corbières) (DNCO, Fig. 2a, c) described above in the Section 4.4. Mattauer and Proust (1962) identified the Combe de Berre diapir (sPZ, NW immediate front of the Écailles de la Berres, Fig. 2a) dating its activity as synorogenic because of the widespread occurrence of bipyramidal quartz in syn-orogenic sediments throughout the stratigraphic column, for example, Maastrichtian to Danian Plantaurel Group between Fontjoncouse and Bizanet area (Fig. 2a) bears witness to the presence of diapirs that pierced to the surface. Ford and Vergés (2021) have recently documented saltcontrolled depocentres, particularly of Early Cretaceous age, in the easternmost North Pyrenean Zone.

In this study, we show strong indications of long-lived salt mobility in the Corbières-Languedoc Transfer Zone by documenting for the first time a Jurassic extension phase, which was decoupled between basement and cover due to the presence of Triassic evaporites. Key observations of this early Mesozoic rifting phase, such as 3D Jurassic thickness variations and Jurassic growth strata, have been found thanks to a detailed field investigation in the NCO (Fig. 5) combined with a stratigraphic correlation along the Corbières Virgation (Fig. 4). These observations allow us to demonstrate the existence of Jurassic salt-related structures (low-dip normal faults, salt roller) and salt-related stratal geometries within the supra salt cover (rollovers, forced folds) (Fig. 14b). These structures have been reactivated during later phases in close relation with basement deformation (Pyrenean orogenesis and Oligo-Miocene extension), and are, despite this, still observable in the landscape.

During Jurassic extension, halokinetic activity was limited in comparison to other regions of Western Europe (e.g. southwestern Alps, Célini et al., 2020; Graham et al., 2012). We demonstrate that two families of oblique thin skinned structures (NE-SW and N110) developed at that time in the original NCO basins (Fig. 14b). The interference between these structures in the presence of salt, leads to the formation of three dimensional growth strata at their intersections (Fig. 14b). We propose that their formation is linked to a strong interaction between oblique inherited basement structures (NE-SW and N110) (Fig. 14b) as during the Jurassic the area lies at the intersection between the eastern part of the Pyrenean E-W trending rift system and the NE-SW trending extensional fault network of the proximal European Tethyan rift margin (e.g. Angrand et al., 2020; Fig. 14a). Considering the tectonic plate scale extensional trend NW-SE oriented of the Central Atlantic-Alpine Tethys region during the Jurassic, the Corbières-Languedoc area corresponds at this time to part of the European Tethyan margin and the Pyrenean domain plays the role of transfer zone (sinistral transtensional) between Atlantic and Alpine Tethys domain (Angrand et al., 2020; Fig. 14a).

We document thickness variations in the Jurassic succession both from SE to NW and from SW to NE (Fig. 4) within the Corbières Virgation. SE to $\mathrm{NW}$ variations are consistent with the large scale extensional trend during the Jurassic and consistent with the activity of NE-SW structures in the basement and the supra-salt cover (Fig. 14). The NE-SW oriented variations can be observed at two scales. The first one is local and in relation to the activity N110 oriented Pyrenean 


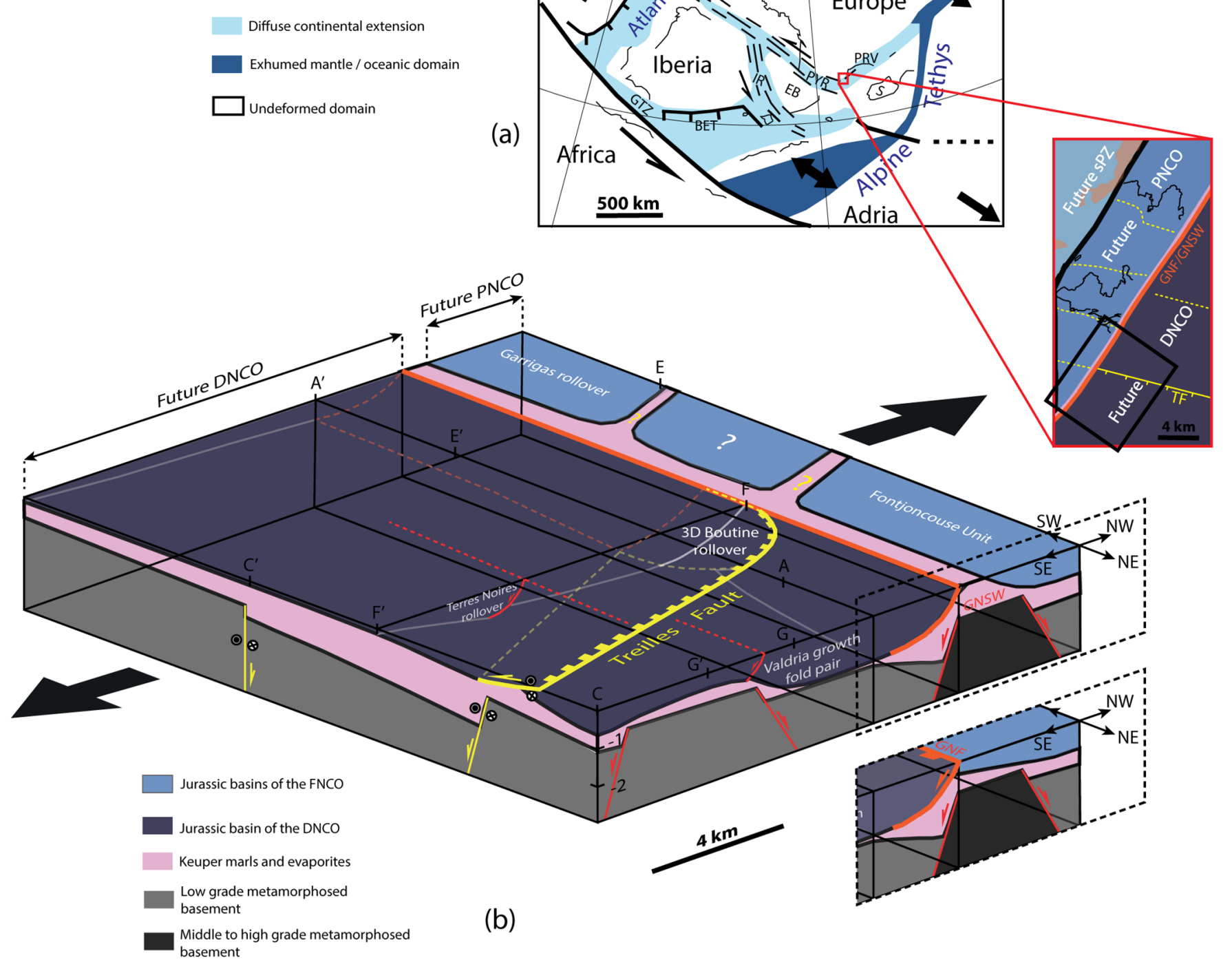

Fig. 14. (a) End Dogger plate reconstruction of the Atlantic-Alpine Tethys linkage zone (adapted from Angrand et al., 2020), showing the location of the Corbières Virgation. Insert shows a schematic map of original Jurassic tectonostratigraphic zones of the study area (CLTZ in the Corbières Virgation portion). The box locates the block diagram in Figure 14b. Abbreviations are GTZ: Gibraltar Transfer Zone; BET: Bethic; IR: Iberian Range basins; EB: Ebro Block; PYR: Pyrenees; PRV: Provence; S: Sardigna. (b) Block diagram showing the restored 3D architecture of Jurassic basins of the future NCO, locating main documented features (Valdria forced folds, Treilles Fault, GNF, Garrigas, Boutine and Terres Noires rollovers). Extension in supra-salt cover was triggered by basement extension (in grey) but decoupled along Keuper evaporites (in pink). 2D to 3D salt and supra-salt structures and stratigraphic geometries (rollovers, forced folds, salt rollers) developed above oblique (NE-SW and N110) basement faults. Considering the NW-SE extension kinematics, the N110 structures are transtensionals. Two model hypothesis are shown for the original structure between the PNCO and the DNCO (GNF: Garrigas-Narbonne Fault or GNSW: Garrigas-Narbonne Salt Wall).

structures (e.g. Treilles Fault and associated basement fault). During NW-SE oriented Jurassic extension, these oblique faults might have been sinistral transtensional as represented on the block diagram (Fig. 14b), meaning that only their normal component is observed on aa' and cc' sections, but we did not found any field evidence to demonstrate this (e.g. Treilles Fault). The second scale of NE-SW oriented variations is regional and demonstrated by an increase of subsidence during the Jurassic from the Eastern Pyrenean rift (e.g. $550 \mathrm{~m}$ in Galamus, Fig. 4) toward the NE in the CLTZ (e.g. $2000 \mathrm{~m}$ in La Clape 1 well, Fig. 4). This is in agreement with Arthaud and Laurent (1995) who show again more important Jurassic thicknesses NW of Montpellier $(3200 \mathrm{~m}$ with $1000 \mathrm{~m}$ of Lias, $1500 \mathrm{~m}$ of Dogger and $450 \mathrm{~m}$ of Malm). We propose to link this larger scale variation to an increasing activity of the Tethyan faults (Cévenoles, NE-SW) toward the $\mathrm{NE}$ and to a relatively inactivity (low subsidence) of the Pyrenean transfer zone, as during the Jurassic, the main transfer area between Atlantic and Alpine Tethys was located south of Iberia (Gibraltar transfer zone, Angrand et al., 2020; Schettino and Turco, 2011). The very low Jurassic extension observed in the supra-salt cover (kilometric) of the Corbières 
Virgation would correspond to far field deformation as (1) the Corbières area lies further (West of restored Corso-Sardinian block, Fig. 14a) from the Alpine Tethys rift axis (East of restored Corso-Sardinian block, Fig. 14a) compared to the Provençal and southwestern Alpine domain. (2) as the Pyrenean transfer zone was relatively inactives during the Jurassic.

\subsection{Post-Jurassic phases}

Along our cross-sections, (Fig. 5) the upper Neocomian and younger stratigraphic units have been eroded. Despite the absence of these deposits, we here discuss the post-Jurassic phases. We did not find any evidence of uplift and erosion attributed to the so called Neocimmerian transpressional event that occurred during the Malm to Neocomian further west in the western retro-foreland basin (Canérot et al., 2005) or in Provence (Tavani et al., 2018).

During the rifting climax in the Pyrenean segment (Aptianlower Cenomanian), the deformation in the CLTZ seems to localize in the futur sub-Pyrenean Zone, especially below the sub-Pyrenean Lower Cretaceous Depocenters (sPLCD, Fig. 2) that record a maximum thickness of Aptian strata (both in the CLTZ and in the Eastern Pyrenees, $1000 \mathrm{~m}$ ) and Albian strata (1000 m) (Berger et al., 1997; Ellenberger et al., 1987; Lespinasse et al., 1982). The NCO basins, more distal in their restored position, instead show thin Aptian series (160 to $320 \mathrm{~m}$, in Opoul-Périllos, Rocquefort-des-Corbières and La Clape areas, Fig. 2a, c) that have been interpreted as the cover of a wide basement high (map length of the whole NCO, Barnolas and Courbouleix, 2001). Albian strata crop out sporadically in the NCO and are always incomplete due to erosion (Fig. 2a). On our cross-sections and their restorations to end of Jurassic, we did not find evidence of Cretaceous activity on preexisting structures. We propose that these structures were inactives during the Berriasian to late Santonian. This is consistent with a localisation of the main transfer area between Atlantic and Alpine Tethys both in the Gibraltar area and the Iberian range area during Malm to Early Aptian (Angrand et al., 2020; Rat et al., 2019). For the Late Aptian to Early Cenomanian period, the regional kinematics is strongly debated. Two different kinematic trends are proposed in the literature, (1) NW-SE oriented, as for previous phases, with pure extension in the NE-SW oriented CorbièresLanguedoc area and with the Pyrenean domain active as a transfer zone between Atlantic and Alpine Tethys domain (e.g. Ford and Vergés, 2021). In this case the Corbières-Languedoc area never was a rift transfer zone during the Mesozoic, but was an orthogonal segment to the kinematics of the NW-SE oriented Mesozoic extension (2) The extensional trend could be N-S oriented (e.g. Ducoux et al., 2021; Tavani et al., 2018), in which case the Corbières-Languedoc area became at that time a rift transfer zone (dextral slightly transtensional) between the Pyrenean and Provençal domains. In both cases, the deformation in the Corbières Virgation seems to be localised on some basement transfer faults (e.g. below sPZ basins).

During the Cenomanian-Santonian post-rift phase (lithospheric thermal subsidence), the NCO basins are intruded by undersaturated alkaline magmas (acid and basic) (Azambre,
1967, 1970; Golberg et al., 1986; Montigny et al., 1986). The current spatial distribution of the different types of intrusions around the Treilles Fault (monchiquites in its footwall, nepheline syenites in the immediate hanging wall and shonkinites in its hanging wall, Figs. $2 b$ and 5) could be related to the spatial distribution of N110 basement faults below the original Mesozoic basins. We propose that the Jurassic basement faults oriented N110 on our block diagram (Fig. 14), were later used as magmatic conduits for each type of intrusion. Because of erosion of the Grey Flysch Group (Fig. 3) in the NCO, no one information relative to this period can be extract from our field analysis. Only the $\mathrm{SPZ}$ is documented to have recorded important subsidence and thickness variations of the Grey Flysch Group (e.g. around Boutenac and Fontfroide, $70 \mathrm{~m}$ to $500 \mathrm{~m}$ observed, probably more, Figs. 2a, c; Ellenberger et al., 1987).

During the N-S compression that leads to Pyrenean orogenesis, the CLTZ was inverted to become an orogenic transfer zone (sinistral slightly transpressive). Although the orogenesis is recorded from latest Santonian to Miocene (Mouthereau et al., 2014) in the central and western Pyrenees, in the Corbières Virgation the syn-orogenic sedimentary record ranges from Campanian to Bartonian in age. Early Pyrenean orogenic phase (late Santonian-Maastrichtian) is well documented in the sPZ (Durand-Delga and Charrière, 2012; Mattauer and Proust, 1962). The main Pyrenean orogenic phase (Ypresian-Bartonian), is well documented in all the foreland (Barnolas and Courbouleix, 2001; Christophoul et al., 2003). The Priabonian (to Rupelian?) is marked by a major detachment of the supra-salt cover from basement along the Keuper evaporites to form the Nappe des Corbières Orientales (Barnolas and Courbouleix, 2001). This model is one century old and is not challenged by this study. In the NCO, basins underwent a weak internal shortening which manifests itself by the formation of NE-SW oriented thrusts and associated folds (e.g. Vingrau, Rocquefort-des-Corbières) or by the gentle inversion of Jurassic features (e.g. Valdria fold pair, Treilles Fault and GNF, rollovers of Garrigas, Terres Noires, la Boutine-la Marende and la Boutine-Roc Traucat), often without being able to clearly identify the timing within the orogenesis due to absence of syn-orogenic strata. Even if these could have initiated during early orogenesis, we propose to associate most of these compressive deformation to the NCO emplacement onto the foreland. The formation of primary welds and the presence of a main secondary detachment in the supra-salt cover (Liassic Marls), leads to a strong basal delamination of the NCO during its emplacement, while blocks were detached from underlying basement fault blocks. The NCO emplacement leads to the destruction of the Cretaceous magmatic pumbing that developped earlier in the Keuper and the Liassic Marls detachment levels as suggeted by the presence of nepheline syenite breccias within the Keuper of the Platrières de Fitou well and the Treilles window.

During Oligo-Miocene extension, the orogenic transfer zone was negatively inverted to form the north-western margin of the Liguro-Provençal back-arc basin (Gulf of Lion passive margin, Fig. 1). We show that in the NCO, some of the NE-SW oriented thrusts underwent a gentle negative inversion (e.g. the Valdria Fault, Fig. 12; the GNF in the Narbonne Fault portion, Fig. 2) and some NE-SW Jurassic normal faults were probably reactivated. We propose that the post-Jurassic normal heave of 
the Treilles Fault (1 km on cc' section to $1.5 \mathrm{~km}$ on aa' section) interpreted in the Section 4.2 could be linked to this extensional phase. On an other hand, if we consider that Pyrenean orogenesis continued until Miocene, this postJurassic normal heave of the Treilles Fault could be linked to an a late activity of the Mouthoumet anticline (post-NCO emplacement in age, Robion et al., 2012), and a gravitational sliding of the supra-salt cover on both sides of the fold, above Keuper and Liassic Marls detachment levels.

\section{Conclusions}

Structural and stratigraphic field observations record Jurassic decoupled extension on oblique (NE-SW and N110) sub- and supra-salt structures in the Corbières Virgation (SW part of the CLTZ). Earlier Pyrenean compressional interpretations do not adequately explain formation of thickness and dip variations across folds and faults of the supra-salt basins that all strongly suggest main growth of these structures during the Jurassic with several later reactivations. At all stages the thin-skinned deformation of the supra-salt cover was decoupled from thick-skinned basement deformation along the Keuper salt level with limited halokinetic activity. The following conclusions summarize the proposed model and its implications:

1 a series of salt related extensional features of Jurassic age are recognized for the first time in the supra-salt cover of the Corbières Virgation area. These include (a) low angle thin skinned extensional faults (e.g. Treilles Fault, Terres Noires Fault and perhaps the Garrigas-Narbonne Fault) associated with hanging wall rollover anticlines (BoutineLa Marende, Boutine-Roc Traucat, Garrigas, Terres Noires), footwall growth syncline (e.g. Pied-du-Poul syncline) and salt rollers (or salt ridges as perhaps the Garrigas-Narbonne Salt Wall). (b) extensional growth forced folds (Valdria);

2 the formation of these Jurassic extensional features in the supra-salt cover was triggered by basement extension but decoupled by Keuper evaporites;

3 two major structural trends are active during Jurassic extension, the N110 oriented Pyrenean trend (e.g. Treilles Fault, Garrigas rollover) and the NE-SW oriented Cévenole/Tethyan trend (e.g. GNF, Valdria, Terres Noires);

4 the interference between these oblique supra-salt structures (NE-SW and N110 oriented), leads to the formation of three dimensional growth strata at their intersection (e.g. Boutine rollover and Pied-du-Poul-Valdria folds intersection);

$5 \mathrm{SE}$ to NW thickness variations are consistent with the large scale NW-SE extensional trend during the Jurassic and consistent with the activity of NE-SW structures in the basement and the supra-salt cover;

6 NE-SW thickness variations can be observed at (a) local scale and in relation to the activity of N110 oriented Pyreneean transtensional structures (e.g. Treilles Fault and associated basement fault). (b) regional scale and linked to an increasing activity of the Tethyan faults toward the NE and a relative inactivity of the Pyrenean transfer zone;

7 the very low Jurassic extension observed in the supra-salt cover (kilometric) of the Corbières Virgation corresponds to far field deformation as the Corbières area lies further from the Alpine Tethys rift axis at the intersection with the almost inactive Pyrenean transfer zone;

8 most Jurassic structures identified in the NCO were inactive during the Berriasian to late Santonian where the most subsident area correspond to the Sub Pyrenean Zone;

9 during Pyrenean orogenesis the supra-salt cover was detached from basement along the Keuper evaporites to form the Nappe des Corbières Orientales. Allochtonous basins underwent a weak internal shortening which manifests itself by the formation of NE-SW oriented thrusts and associated folds (e.g. Vingrau, Rocquefortdes-Corbières) or by the gentle inversion of Jurassic features (e.g. Valdria fold pair, Treilles Fault and GNF/ GNSW, rollovers of Terres Noires, la Boutine-la Marende, la Boutine-Roc-Traucat and Garrigas);

10 due to formation of primary welds during inversion, any rugosity along the base of the suprasalt cover was sheared off during this lateral transport to give a smooth topKeuper detachment rich in sub- and supra-salt strata blocks;

11 in addition to the Keuper detachment, the presence of the Liassic Marls detachment in the lower part of the Jurassic stratigraphic pile facilitates the strong basal deformation of the NCO;

12 during Oligo-Miocene extension, the orogenic CLTZ was negatively inverted to form the north-western margin of the Liguro-Provençal back-arc basin (Gulf of Lion passive margin). Some of the NE-SW oriented thrusts of the NCO underwent a gentle negative inversion (e.g. the Valdria Fault and the GNF in the Narbonne Fault portion), and the N110 Treilles Fault underwent late negative inversion.

Associated to previous works, this study highlights that the CLTZ is a key area to better understand Pyreneo-Provençal system evolution along its whole Wilson cycle and to better understand the processes that govern the formation of a saltrich transfer zone in a strongly pre-structured crust, its multiple reactivations and the decoupling role of pre-rift salt.

Acknowledgements. This work was funded by the OROGEN project financed by Total, the BRGM and the CNRS. Our thanks go to our colleagues for numerous discussions, with special thanks to J. Léger, V. Wicker, V. Payet, S. Ternois, P. Angrand, G. Frasca., A. Laffitte., F. Christophoul and M. Ducoux. We also thank our colleagues of the OROGEN project for their support and discussions. We thank our editor O. Lacombe, associate editor S. Tavani and our reviewers D. Frizon de Lamotte and Naïm Célini for their thorough and helpful analysis of our manuscript and for their constructives suggestions that greatly improved the paper.

\section{References}

Alabouvette B, Arthaud F, Bambier A, Paloc H. 1985. Carte géologique de la France au 1:50 000. Note explicative de la feuille 1014 : St-Chinian. Orléans: BRGM, 44 p., 2 fig. 
Angrand P, Ford M, Watts AB. 2018. Lateral Variations in Foreland Flexure of a Rifted Continental Margin: The Aquitaine Basin (SW France). Tectonics 37(2): 430-449. https://doi.org/10.1002/ 2017 TC004670.

Angrand P, Mouthereau F, Masini E, Asti R. 2020. A reconstruction of Iberia accounting for $\mathrm{W}$-Tethys/N-Atlantic kinematics since the late Permian-Triassic. Solid Earth Discuss: 1-24. https://doi.org/ 10.5194/se-2020-24.

Arthaud F, Mattauer M. 1972. Présentation d'une hypothèse sur la genèse de la virgation pyrénéenne du Languedoc et la structure profonde du golfe du Lion. C R Acad Seism Paris D 274: 524-527.

Arthaud F, Séguret M. 1981. Les structures pyrénéennes du Languedoc et du golfe du Lion (sud de la France). Taureau Soc Geol Fr S7-XXIII(1): 51-63.

Arthaud F, Durand V. 1982. Relations entre chevauchements et décrochements dans la tectonique pyrénéenne du « Pli de Montpellier » (Languedoc, France). C R Acad Sci 309: 1387-1393.

Arthaud F, Laurent P. 1995. Stress deformation and displacement within the North Pyrenean foreland of the Mediterranean Languedoc. Geodin Acta 8: 142-157.

Azambre B. 1967. Sur les roches intrusives sous-saturées du Crétacé des Pyrénées (picrites, teschénites, monchiquites, syénites néphéliniques). Thèse $3^{\mathrm{e}}$ cycle. Paris, 147 p., $19 \mathrm{pl}$.

Azambre B. 1970. Monchiquites et autres roches intrusives basiques accompagnant les syénites néphéliniques des Corbières. $C R \mathrm{Acad}$ Sci Paris 271: 641-643.

Azambre B, Rossy M. 1981. Caractère alcalin du magmatisme triasique des Corbières orientales. Bull Soc Geol Fr 7: 253-262.

Barnolas A, Courbouleix S. 2001. Synthèse géologique et géophysique des Pyrénées. In: Cycle Alpin : phénomènes alpins, vol. 3. BRGM, ITGE.

Barrabé L. 1922. Sur la présence de nappe de poussée dans les Corbières orientales. C R Acad Sci 1(175): 1081.

Barrabé L. 1923. Tectonique des Corbières orientales. Taureau Serv Carte Geol Fr 27(151): 21-31.

Barrabé L. 1938. Sur la structure de l'extrémité méridionale du chaînon de Saint-Chinian. C R Soc Hist Nat Toulouse 80: 119-144.

Barrabé L. 1948. Fiche au 1/80 000 de Narbonne et Marseillan avec note explicative (2e éd.). Ser Carte Geol Fr.

Barrabé L. 1958. Grandes lignes de la structure des Corbières Orientales. Bull Soc Geol Fr WLIII(21): 811-824.

Bache F. 2009. Évolution Oligo Miocène des marges du micro océan Liguro-Provençal. PhD Thesis. Université de Bretagne occidentale. HAL Id: tel-00326616. https://tel.archives-ouvertes.fr/tel$00326616 \mathrm{v} 2$.

Bache F, Olivet JL, Gorini C, Aslanian D, Labails C, Rabineau M. 2010. Evolution of rifted continental margins: the case of the Gulf of Lions (Western Mediterranean Basin). Earth Planet Sci Lett 292 (3-4): 345-356. https://doi.org/10.1016/j.eps1.2010.02.001.

Beaumont C, Muñoz JA, Hamilton J, Fullsack P. 2000. Factors controlling the Alpine evolution of the central Pyrenees inferred from a comparison of observations and geodynamical models. J Geophys Res Solid Earth 105(B4): 8121-8145. https://doi.org/ 10.1029/1999jb900390.

Bellahsen N, Leroy S, Autin J, Razin P, d'Acremont E, Sloan H, et al. 2013. Pre-existing oblique transfer zones and transfer/transform relationships in continental margins: new insights from the southeastern Gulf of Aden, Socotra Island, Yemen. Tectonophysics 607: 32-50. https://doi.org/10.1016/j.tecto.2013.07.036.

Berger GM, Aloïsi J-C, Got H, Marchal J-P, Martin R, Michaux J, et al. 1982. Carte géologique de la France au 1:50 000. Note explicative de la feuille 1079: Leucate. Orléans: BRGM, 42 p., 1 fig.

Berger GM, Fonteilles M, Leblanc D, Clauzon G, Marchal JP, Vautrelle C. 1993. Notice explicative, carte géol. France (1/50 000), feuille Rivesaltes (1090). Orléans: BRGM, 119 p., carte géologique par M. Fonteilles, D. Leblanc, G. Clauzon, J.L. Vaudin, G.M. Berger (1993).

Berger GM, Alabouvette B, Bessière G, Bilotte M, Crochet B, Dubar M, et al. 1997. Carte géologique de la France au 1/50 000. Notice explicative de la feuille 1078: Tuchan. Orléans: BRGM, 113 p., 12 fig.

Bertrand L. 1906. Contribution à l'histoire stratigraphique et tectonique des Pyrénées orientales et centrales. Taureau Serv Carte Geol Fr 118: 17.

Béziat D, Joron JL, Monchoux P, Treuil M, Walgenwitz F. 1991. Implications géodynamiques des données géochimiques pour les ophites pyrénéens (Espagne-France). Chem Geol 89: 243-262. https://doi.org/10.1016/0009-2541(91)90019-N.

Bosworth W. 1985. Geometry of propagating continental rifts. Nature 316: 625-627.

Canérot J, Hudec MR, Rockenbauch K. 2005. Mesozoic diapirism in the Pyrenean orogen: salt tectonics on a transform plate boundary. AAPG Bull 89(2): 211-229. https://doi.org/10.1306/09170404007.

Casteras M, Viallard P. 1961. Sur l'allure de la constitution du front chevauchant de l'unité de Jonquières et de Fontjoncouse dans les Corbières orientales. C R Somm Soc Geol Fr: 230-231.

Célini N, Callot JP, Ringenbach JC, Graham R. 2020. Jurassic Salt Tectonics in the SW Sub-Alpine Fold-and-Thrust Belt. Tectonics 39. https://doi.org/10.1029/2020TC006107.

Charrière A. 1979. Étude géologique du lambeau de recouvrement de Taura et de son substratum entre Ripaud et Pech-Rascas (Corbières orientales-Aude). Thèse $3^{\mathrm{e}}$ cycle. Toulouse: Univ. Paul Sabatier, 182 p., 1 carte géol.

Charrière A. 1980. Un exemple de charriage épiglyptique : le lobe de recouvrement de Taura (nappe des Corbières orientales, Aude). Rev Geogr Phys Geol Dynam 22(4-5): 293-302.

Choukroune P, Roure F, Pinet B. 1990. Main results of the ECORS Pyrenees profile. Tectonophysics 173(1-4): 411-423. https://doi. org/10.1016/0040-1951(90)90234-Y.

Christophoul F, Soula J-C, Brusset S, Elibana B, Roddaz M, Bessiere $\mathrm{G}$, et al. 2003. Time, place and mode of propagation of foreland basin systems as recorded by the sedimentary fill: examples of the Late Cretaceous and Eocene retro-foreland basins of the northeastern Pyrenees. Geol Soc Lond Spec Publ 208(1): 229-252. https://doi.org/10.1144/GSL.SP.2003.208.01.11.

Clerc C, Lahfid A, Monié P, Lagabrielle Y, Chopin C, Poujol M, et al. 2015. High-temperature metamorphism during extreme thinning of the continental crust: a reappraisal of the north Pyrenean paleopassive margin. Solid Earth Discuss 7: 797-857. https://doi.org/ 10.5194/sed-7-797-2015.

Cluzel D. 1977. Étude microtectonique de l'avant-pays de la nappe des Corbières orientales (Aude-France). Univ. Paris-Sud.

Conand C, Mouthereau F, Ganne J, Lin AT-S, Lahfid A, Daudet M, et al. 2020. Strain Partitioning and Exhumation in Oblique Taiwan Collision: Role of Rift Architecture and Plate Kinematics. Tectonics 39: e2019TC005798. https://doi.org/10.1029/ 2019TC005798.

Cornet C. 1980. Genèse structurale des Corbières. Taureau Soc Geol Fr 7-XXII(2): 179-184.

Dagnac J. 1965. Étude géologique du chaînon de Fontfroide (Aude). Toulouse University.

Debrand-Passard S, Courbouleix S, Lienhart M-J. 1984. Synthèse géologique du Sud Est de la France. Mémoires du BRGM, n ${ }^{\text {os }} 125$ et 126,2 volumes, $615 \mathrm{p}$.

Destombes J-P. 1949. Contribution à l'étude du Trias salifère de la région nord-orientale des Pyrénées. Les sondages de Fitou. Publ BRGM 7: 144 p. 
Donnadieu J-P. 1973. Étude géologique de la région de FeuillaRoquefort (Aude-Corbières). Thèse $3^{\mathrm{e}}$ cycle, Paris VI, 101 p., 1 pi.

Ducoux M, Jolivet L, Cagnard F, Baudin T. 2021. Basement-cover decoupling during the inversion of a hyperextended basin: insights from the Eastern Pyrenees. Tectonics 40. https://doi.org/10.1029/ 2020 TC006512.

Dufaur P. 1964. Stratigraphie du Crétacé du Crétacé inférieur et du Jurassique dans le forage de la Clape 1 (Aude). C R Acad Sci Paris 258: 266-268.

Dujon SC, Ellenberger F, Plaziat J-C. 1964. Un nouveau lambeau avancé de la nappe des Corbières orientales sur le plateau de Poursan (Aude) ; structures de troncature basale et réactions du substrat. C R Somm Soc Geol Fr 2: 46-48.

Durand-Delga M. 1964. Manifestation d'une phase tectonique importante anté-cénomanienne dans les Corbières orientales. Bull Soc Hist Nat Toulouse 100: 81-95.

Durand-Delga M. 1983. Évolution récente des idées sur la structure alpine des Pyrénées. Taureau Technol Elf-Aquitaine 106: $11 \mathrm{p}$.

Durand-Delga M, Charrière A. 2012. Tectonique tangentielle finicrétacée au front NE du massif de mouthoumet (Pinède de Durban - Serre de Ginoufré, Corbières, Aude). Geol Fr (2): 25-48.

Ellenberger F. 1967. Les interférences de l'érosion et de la tectonique tangentielle tertiaire dans le Bas-Languedoc. Rev Geogr Phys Geol Dynam IX(2): 87-42.

Ellenberger F, Freytet P, Plaziat J-C, Bessière G, Viallard P, Berger GM, et al. 1987. Carte géologique de la France au 1/50 000. Notice explicative de la feuille 1060 : Capendu. Orléans: BRGM, 88 p., 11 fig.

Espurt N, Wattellier F, Philip J, Hippolyte JC, Bellier O, Bestani L. 2019a. Mesozoic halokinesis and basement inheritance in the eastern Provence fold-thrust belt, SE France. Tectonophysics 766: 60-80. https://doi.org/10.1016/j.tecto.2019.04.027.

Espurt N, Angrand P, Teixell A, Labaume P, Ford M, de Saint Blanquat $\mathrm{M}$, et al. 2019b. Crustal-scale balanced cross-section and restorations of the Central Pyrenean belt (Nestes-Cinca transect): highlighting the structural control of Variscan belt and PermianMesozoic rift systems on mountain building. Tectonophysics 764 : 25-45. https://doi.org/10.1016/j.tecto.2019.04.026.

Faulds JE, Varga RJ. 1998. The role of accommodation zones and transfer zones in the regional segmentation of extended terranes. In Faulds JE, Stewart JH, eds.Accommodation Zones and Transfer Zones: The Regional Segmentation of the Basin and Range Provinces. Geological Society of America Special Paper, pp. 1-45.

Fauré P. 1980/1981. Le Lias de la Nappe des Corbières Orientales (Pyrénées navarro-languedociennes) (feuilles de Capendu, Leucate, Narbonne et Tuchan). Bull Bur Rech Geol Min 1/2: 135-151.

Fauré P, Alméras Y. 2004. Le Dogger (Jurassique moyen) des Corbières (Aude, France). Biostratigraphie, évolution paléogéographique. Bull Soc Etudes Sci Aude 104: 9-23.

Fauré P, Alméras Y. 2006. Le Dogger de la parte orientale des Pyrénées franco-espagnoles (Aude, France et Haute-Catalogne, Espagne). Rev Paleobiol 25(2): 643-670.

Ford M, Le Carlier de Veslud C, Bourgeois O. 2007. Kinematic and geometric analysis of fault related folds in a rift setting: The Dannemarie basin, Upper Rhine Graben, France. J Struct Geol 29: 1811-1830. https://doi.org/10.1016/j.jsg.2007.08.001.

Ford M, Hemmer L, Vacherat A, Gallagher K, Christophoul F. 2016. Retro-wedge foreland basin evolution along the ECORS line, eastern Pyrenees, France. J Geol Soc 173(3): 419-437. https://doi. org/10.1144/jgs2015-129.

Ford M, Vergés J. 2021. Evolution of a salt-rich transtensional rifted margin, eastern North Pyrenees, France. J Geol Soc Lond: jgs2019157. https://doi.org/10.1144/jgs2019-157.
Fossen H, Rotevatn A. 2016. Fault linkage and relay structures in extensional settings - a review. Earth Sci Rev 154: 14-28.

Gattacceca J, Deino A, Rizzo R, Jones DS, Henry B, Beaudoin B, et al. 2007. Rotation miocène de la Sardaigne : nouvelles contraintes paléomagnétiques et géochronogiques et implication géodynamique. Planète Terre Sci Lett 258: 359-377.

Gawthorpe RL, Hurst JM. 1993. Transfer zones in extensional basins: their structural style and influence on drainage development and stratigraphy. J Geol Soc Lond 150: 1137-1152. https://doi.org/ 10.1144/gsjgs.150.6.1137.

Golberg JM, Maluski H, Leyreloup AF. 1986. Petrological and age relationship between emplacement of magmatic breccia, alkaline magmatism, and static metamorphism in the North Pyrenean Zone. Tectonophysics 129(1-4): 275-290. https://doi.org/10.1016/ 0040-1951(86)90256-8.

Golberg JM, Maluski H. 1988. Donnees nouvelles et mise au point sur l'âge du métamorphisme pyrénéen. Discuter de nouvelles données. Metamorph Pyrén Age 306: 429-435.

Gorini C, Viallard P, Deramond J. 1991. Modèle d'inversion négative : la tectonique extensive post-nappes du fossé de Narbonne-Sigean. C R Acad Sci Paris 312: 1013-1019.

Gorini C, Le Marec A, Mauffret A. 1993. Contribution à l'histoire structurale et sédimentaire du golfe du Lions (Méditerranée occidentale), à partir des profils ECORS, des profils sismiques industriels et des données wel. Bull Soc Geol Fr 164(3): 353-363.

Graciansky de PC, Dardeau G, Lemoine M, Tricart P. 1989. The inverted margin of the French Alps and foreland basin inversion. In: Cooper MA, Williams GD, eds. Inversion Tectonics. Geological Society, London, Special Publications, pp. 87-104.

Graham R, Jackson M, Pilcher R, Kilsdonk B. 2012. Allochthonous salt in the sub-Alpine fold-thrust belt of Haute Provence, France. Geol Soc Lond Spec Publ 363: 595-615. https://doi.org/10.1144/ SP363.30.

Grool AR, Ford M, Vergés J, Huismans RS, Christophoul F, Dielforder A. 2018. Insights into the crustal-scale dynamics of a doubly vergent orogen from a quantitative analysis of its forelands: A case study of the Eastern Pyrenees. Tectonics 37(2): 450-476. https://doi.org/10.1002/2017TC004731.

Guennoc P, Gorini C, Mauffret A. 2000. Histoire géologique du golfe du Lion et cartographie du rift oligo-aquitanien et de la surface messinienne. Geol Fr 3: 67-97.

Handy MR, Schmid S, Bousquet R, Kissling E, Bernoulli D. 2010. Reconciling plate-tectonic reconstructions of Alpine Tethys with the geological-geophysical record of spreading and subduction in the Alps. Earth Sci Rev 102: 121-158. https://doi.org/10.1016/j. earscirev.2010.06.002.

Huyghe D, Mouthereau F, Ségalen L, Furió M. 2020. Long-term dynamic topographic support during post-orogenic crustal thinning revealed by stable isotope $(\delta 18 \mathrm{O})$ paleo-altimetry in eastern Pyrenees. Sci Rep 10: 1-8. https://doi.org/10.1038/ s41598-020-58903-w.

Jackson MP, Hudec MR. 2017. Salt Tectonics: Principles and Practice. Cambridge University Press.

Jaffrezo M. 1970. Precisions stratigraphiques et tectoniques sur le lobe de Fontjoncouse de la nappe des Corbieres orientales. Bull Soc Geol Fr S7-XII(1): 65-77. https://doi.org/10.2113/gssgfbull.S7XII.1.65.

Jaffrezo M. 1977. Pyrénées Orientales, Corbières. Guides Géologiques Régionaux. Masson Éditeur, 190 p.

Labaume P, Teixell A. 2020. Evolution of salt structures of the Pyrenean rift (Chaînons Béarnais, France): from hyper-extension to tectonic inversion. Tectonophysics: 228451. https://doi.org/ 10.1016/j.tecto.2020.228451. 
Jolivet L, Gorini C, Smit J, Leroy S. 2015. Back-arc basins: the Gulf of Lion margin. https://doi.org/10.1002/2014TC003570.

Jolivet L, Romagny A, Gorini C, Maillard A, Thinon I, Couëffé R, et al. 2020. Fast dismantling of a mountain belt by mantle flow: Late-orogenic evolution of Pyrenees and Liguro-Provençal rifting. Tectonophysics 776: 228312. https://doi.org/10.1016/j. tecto.2019.228312.

Lacombe O, Jolivet L. 2005. Structural and kinematic relationships between Corsica and the Pyrenees-Provence domain at the time of the Pyrenean orogeny. Tectonics 24(1). https://doi.org/10.1029/ 2004TC001673.

Lagabrielle Y, Labaume P, de Saint Blanquat M. 2010. Mantle exhumation, crustal denudation, and gravity tectonics during Cretaceous rifting in the Pyrenean realm (SW Europe): insights from the geological setting of the lherzolite bodies. Tectonics 29: TC4012.

Lemoine M, Bas T, Arnaud-Vanneau A, Arnaud H, Dumont T, Gidon M, et al. 1986. The continental margin of the Mesozoic Tethys in the western Alps. Mar Pet Geol 3: 179-199.

Lespinasse P. 1965. Les phénomènes tectoniques liés au charriage des terrains secondaires sur la bordure sud-est du massif de Mouthoumet (Corbières orientales, Aude). C R Acad Sci 260: 6139-6142.

Lespinasse P, Aloïsi J-C, Barruol JH, Monaco A, Marchal J-P. 1982. Carte géologique de la France au 1/50 000. Notice explicative de la feuille 1061 : Narbonne. Orléans: BRGM, 51 p., 6 fig.

Lewis MM, Jackson CAL, Gawthorpe RL. 2013. Salt-influenced normal fault growth and forced folding: The Stavanger Fault System, North Sea. J Struct Geol 54: 156-173. https://doi.org/ 10.1016/j.jsg.2013.07.015.

Leyreloup A, Burg JP. 1976. Découverte de paragneiss khondalitiques de faciès granulite de haute pression en «enclaves» dans le Trias des Corbières (boutonière de Treilles, Pyrénées orientales). Implications tectoniques. C R Acad Sci Paris 283: 443-446.

Konstantinovskaya EA, Harris LB, Poulin J, Ivanov GM. 2007. Transfer zones and fault reactivation in inverted rift basins: Insights from physical modelling. Tectonophysics 441: 1-26. https://doi. org/10.1016/j.tecto.2007.06.002.

Macchiavelli C, Vergés J, Schettino A, Fernàndez M, Turco E, Casciello E, et al. 2017. A New Southern North Atlantic Isochron Map: Insights Into the Drift of the Iberian Plate Since the Late Cretaceous. J Geophys Res Solid Earth 122(12): 9603-9626. https://doi.org/10.1002/2017JB014769.

Mascle A, Vially R, Deville E, Biju-Duval B, Roy JP. 1996. The petroleum evaluation of a tectonically complex area: The western margin of the Southeast Basin (France). Mar Pet Geol 13(8): 941961. https://doi.org/10.1016/S0264-8172(96)00041-4.

Mattauer M, Proust F. 1962. Sur la tectonique de la fin du Crétacé et du début du Tertiaire en Languedoc. Rev Geol Dyn Geogr Phys 2: 5-11.

Mauffret A, Durand de Grossouvre B, Tadeu Dos Reis A, Gorini C, Nercessian A. 2001. Structural geometry in the eastern Pyrenees and western Gulf of Lion (Western Mediterranean). J Struct Geol 23(11): 1701-1726. https://doi.org/10.1016/S0191-8141(01) 00025-6.

McClay KR, Dooley T, Whitehouse P, Mills M. 2002. 4-D evolution of rift systems: Insights from scaled physical models. Am Assoc Pet Geol Bull 86: 935-959. https://doi.org/10.1306/61 eedbf2-173e$11 \mathrm{~d} 7-8645000102 \mathrm{c} 1865 \mathrm{~d}$.

McKenzie D. 1978. Some remarks on the development of sedimentary basins. Earth Planet Sci Lett 40: 25-32.

Mohn G, Manatschal G, Müntener O, Beltrando M, Masini E. 2010. Unravelling the interaction between tectonic and sedimentary processes during lithospheric thinning in the Alpine Tethys margins. Int J Earth Sci 99: 75-101. https://doi.org/10.1007/ s00531-010-0566-6.

Montigny R, Azambre B, Rossy M, Thuizat R. 1982. Étude K/Ar du magmatisme basique au Trias supérieur des Pyrénées ; conséquences méthodologiques et paléogéographiques. K/Ar Study Basic Magmat. Up. Méthodole des Pyrénées triasiques. Conséquences paléogéographiques 105: 673-680.

Montigny R, Azambre B, Rossy M, Thuizat R. 1986. K-Ar du magmatisme et métamorphisme crétacé des Pyrénées : âge et durée de rotation de la péninsule ibérique. Tectonophysics 129: 257-273.

Morley CKK, Nelson RA, Patton TL, Munn SG. 1990. Transfer zones in the East African rift system and their relevance to hydrocarbon exploration in rifts. Bull Am Assoc Pet Geol 74: 1234-1253.

Mouthereau F, Filleaudeau P-Y., Vacherat A, Pik R, Lacombe O, Fellin MG, et al. 2014. Placing limits to shortening evolution in the Pyrenees: Role of margin architecture and implications for the Iberia/Europe convergence. Tectonics 33(12): 2283-2314. https:// doi.org/10.1002/2014TC003663.

Nirrengarten M, Manatschal G, Tugend J, Kusznir N, Sauter D. 2018. Kinematic evolution of the southern North Atlantic: implications for the formation of hyperextended rift systems. Tectonics 37: 89118. https://doi.org/10.1002/2017TC004495.

Olivet J. 1996. La cinématique de la plaque ibérique. Taureau Cent Rech Explor Prod Elf Aquitaine 20(1): 131-195.

Peron-Pinvidic G, Manatschal G, Osmundsen PT. 2013. Structural comparison of archetypal Atlantic rifted margins: a review of observations and concepts. Mar Pet Geol. https://doi.org/10.1016/j. marpetgeo.2013.02.002.

Quintana L, Alonso JL, Pulgar JA, Rodríguez-Fernández LR. 2006. Transpressional inversion in an extensional transfer zone (the Saltacaballos fault, northern Spain). J Struct Geol 28: 2038-2048. https://doi.org/10.1016/j.jsg.2006.06.013.

Rat J, Mouthereau F, Brichau S, Crémades A, Bernet M, Balvay M, et al. 2019. Tectonothermal Evolution of the Cameros Basin: Implications for Tectonics of North Iberia. Tectonics 38: 440-469. https://doi.org/10.1029/2018TC005294.

Raymond D. 1965. Le problème de la prolongation oriental du front nord-pyrénéen dans la région de Tuchan. C R Acad Sci 260: 5822 5825.

Reston TJ. 2009. The structure, evolution and symmetry of the magma-poor rifted margins of the North and Central Atlantic: A synthesis. Tectonophysics 468: 6-27. https://doi.org/10.1016/j. tecto.2008.09.002.

Robion P, Humbert F, Colombier J-C., Leghay S, De Lamotte DF. 2012. Relationships between pore space anisotropy and anisotropy of physical properties of silicoclastic rocks from the CorbièresMinervois fold-and-thrust-belt (north-east Pyrenees,France). Tectonophysics 576-577: 63-77.

Rougier G, Ford M, Christophoul F, Bader A-G. 2016. Stratigraphic and tectonic studies in the central Aquitaine Basin, northern Pyrenees: constraints on the subsidence and deformation history of a retro-foreland basin. C R Geosci 348(3-4): 224-235. https://doi. org/10.1016/j.crte.2015.12.005.

Roure F, Choukroune P, Berastegui X, Muñoz JA, Villien A, Matheron P, et al. 1989. Données sismiques profondes d'Ecors et sections efficaces équilibrées : contraintes géométriques sur l'évolution des Pyrénées. Tectonique 8(1): 41-50. https://doi.org/ 10.1029/TC008i001p00041.

Rouvier H, Henry B, Le Goff M. 2012. Mise en évidence par le paléomagnétisme de rotations régionales dans la virgation des Corbières (France). Bull Soc Geol Fr 183(5): 409-424. https://doi. org/10.2113/gssgfbull.183.5.409. 
Sarfati BJ. 1964. Étude structural et micropaléontologique des massifs jurassiques et crétacés du Pied-du-Poul et de Périllos (Aude et Pyrénées-orientales). Thèse de $3^{\mathrm{e}}$ cycle. Paris.

Schettino A, Turco E. 2011. Tectonic history of the western Tethys since the Late Triassic. Geol. Soc. Am. Bull. 123: 89-105.

Schlische RW, Withjack MO. 2009. Origin of fault domains and faultdomain boundaries (transfer zones and accommodation zones) in extensional provinces: Result of random nucleation and selforganized fault growth. J Struct Geol 31: 910-925. https://doi.org/ 10.1016/j.jsg.2008.09.005.

Séranne M. 1999. The Gulf of Lion continental margin (NW Mediterranean) revisited by IBS: an overview. Geol Soc Lond Spec Publ 156(1): 15-36. https://doi.org/10.1144/GSL.SP.1999.156.01.03.

Sibuet J-C, Srivastava SP, Spakman W. 2004. Pyrenean orogeny and plate kinematics. J Geophys Res Solid Earth 109(B8): 1-18. https:// doi.org/10.1029/2003JB002514.

Soto JI, Flinch JF, Tari G. 2017. Permo-Triassic Salt Provinces of Europe, North Africa and the Atlantic Margins. Elsevier, 608 p.

Tavani S, Bertok C, Granado P, Piana F, Salas R, Vigna B, et al. 2018. The Iberia-Eurasia plate boundary east of the Pyrenees. Earth Sci Rev 187: 314-337. https://doi.org/10.1016/j.ear scirev.2018.10.008.

Teixell A, Labaume P, Lagabrielle Y. 2016. The crustal evolution of the west-central Pyrenees revisited: Inferences from a new kinematic scenario. C R Geosci 348(3-4): 257-267. https://doi. org/10.1016/j.crte.2015.10.010.

Ternois S, Odlum M, Ford M, Pik R, Stockli D, Tibari B, et al. 2019. Thermochronological Evidence of Early Orogenesis, Eastern Pyrenees, France. Tectonics 38(4): 1308-1336. https://doi.org/ 10.1029/2018TC005254.

Tugend J, Manatschal G, Kusznir NJ. 2015. Spatial and temporal evolution of hyperextended rift systems: Implication for the nature, kinematics, and timing of the Iberian-European plate boundary. Geology 43(1): 15-18. https://doi.org/10.1130/G36072.1.
Vergés J, Millán H, Roca E, Muñoz JA, Marzo M, Cirés J, et al. 1995. Eastern Pyrenees and related foreland basins: pre-, syn- and postcollisional crustal-scale cross-sections. Mar Pet Geol 12(8): $903-$ 915. https://doi.org/10.1016/0264-8172(95)98854-X.

Vergés J, Poprawski Y, Almar Y, Drzawiecki PA, Moragas M, BovarArnal T, et al. 2020. Tectono-sedimentary evolution of JurassicCretaceous diapiric structures: Miravete anticline, Maestrat Basin, Spain. Basin Res 0-21. https://doi.org/10.1016/j.optmat.2011.11.002.

Viallard P. 1963. Étude de la couverture du massif du Mouthoumet entre Thézan et la Berre. Thèse de $3^{\mathrm{e}}$ cycle. Toulouse: Fac. des Sciences.

Viallard P. 1987. Un modèle de charriage épiglyptique : la nappe des Corbières orientales (Aude, France). Taureau Soc Geol Fr 3(3): 551-559.

Viallard P, Gorini C. 1994. Modalités de la fracturation d'une marge passive préstructurée: le golfe du Lion (Méditerranée nordoccidentale). C R Acad Sci Paris 319: 56-572.

Vielzeuf D, Pin C. 1991. Granulites orthodérivées d'âge tardihercynien; exemple de la norite de Treilles, Corbières (Aude, France). Bull Soc Geol Fr 162: 1057-1066.

Vila JM. 1964. Contribution à l'étude géologique de la région de Durban-Corbières (Corbières orientales). Paris: Dipl. et. sup., $114 \mathrm{p}$.

Vila JM. 1965. Relations entre la nappe des Corbières orientales et son substratum, dans la région de Durban-Corbières (Aude). C R Acad Ensemble 260: 1700-1703.

Warsitzka M, Kley J, Kukowski N. 2013. Salt diapirism driven by differential loading - Some insights from analogue modelling. Tectonophysics 591: 83-97. https://doi.org/10.1016/j. tecto.2011.11.018.

Withjack MO, Calloway S. 2000. Active normal faulting beneath a salt layer: an experimental study of deformation patterns in the cover sequence. Am Assoc Pet Geol Bull 84: 627-651.

Withjack MO, Òlson J, Peterson E. 1990. Exterimental models of extensional forced folds. Am Assoc Pet Geol Bull 74: 1038-1054.

Cite this article as: Crémades A, Ford M, Charreau J. 2021. Evidence of decoupled deformation during Jurassic rifting and Cenozoic inversion phases in the salt-rich Corbières-Languedoc Transfer Zone (Pyreneo-Provençal orogen, France), BSGF - Earth Sciences Bulletin 192: 37. 